\title{
Cloning and characterization of organic anion transport systems in the adrenal cortex and their role in steroid release
}

\author{
Dissertation \\ zur Erlangung des Doktorgrades \\ der Mathematisch-Naturwissenschaftlichen Fakultäten \\ der Georg-August-Universität zu Göttingen
}

\author{
vorgelegt von \\ Erzsébet Kornélia Beéry \\ aus Dunaújváros, Ungarn
}

Göttingen 2000 
D7

Referent:

Prof. Dr. H. W Heldt

Korreferent:

Prof. Dr. K. Jungermann

Tag der mündlichen Prüfung: 


\begin{tabular}{|c|c|}
\hline \multicolumn{2}{|r|}{ ABSTRACT } \\
\hline & INTRODUCTION \\
\hline 1.1 & OMY C \\
\hline 2 & MONES OF THE ADRENAL GLAND ......... \\
\hline .2 .1 & Steroid hormone biosynthesis . \\
\hline 1.2 .2 & Regulation of adrenal function. \\
\hline .2 .3 & Transport of hormones in blood. \\
\hline 1.2 .4 & Actions of adrenal hormones .. \\
\hline 1.3 & MOVEMENT OF STEROID HORMONES THROUGH THE PLASMA MEMBRANE................. \\
\hline 1.3 .1 &  \\
\hline .3 .2 & The multispecific organic anion transport system (OAT) ................. \\
\hline .3 .3 &  \\
\hline 1.4 & 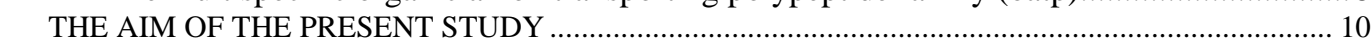 \\
\hline 2 & MATERIALS \\
\hline 2.1 & CHEMICALS . \\
\hline 2.2 & ENZYMES . \\
\hline 2.3 & BUFFERS. \\
\hline 2.4 & OLIGONUCLEOTIDES. \\
\hline .5 & KITS .. \\
\hline 2.6 & BACTERIA. \\
\hline .7 & PLASMID VECTORS \\
\hline 2.8 & RADICHEMICALS. \\
\hline 2.9 & CELL LINES ... \\
\hline 10 & CELL CULTURE MEDIA \\
\hline 11 & CELL CULTURE MEDIA SUPPLEMENTS \\
\hline 12 & SEQUENCE ANALYSIS SOFTWARES AND ONLI \\
\hline 2.13 & 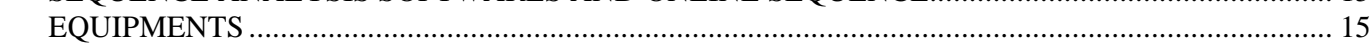 \\
\hline & (1) \\
\hline 1 & ISOL \\
\hline 2 & ISOL \\
\hline 3 & $\mathrm{cDN}$ \\
\hline 4 & POL \\
\hline 3.4.1 & .20 \\
\hline .4 .2 & Hig \\
\hline 3.5 & SITE DIRECTED MU \\
\hline 3.6 & RESTRICTION DIGES \\
\hline .7 & LIGATION \\
\hline 8 & AGAI \\
\hline 3.9 & GEL I \\
\hline 3.10 & PCR PUR \\
\hline 11 & NON-RADIOACTIVE TE \\
\hline 12 & CLON \\
\hline 12.1 & \\
\hline 3.12 .2 & $\mathrm{pPC}$ \\
\hline 3.12 .3 & One Shot ${ }^{\mathrm{TM}}$ Trans \\
\hline 13 & NON-H \\
\hline 3.1 & .28 \\
\hline 3.13 .2 & Non-radioactive in situ hybrid \\
\hline 3.14 & cRNA synthesis.. \\
\hline 15 & BOVINE ADREN \\
\hline .15 .1 & \\
\hline 16 & CULTIVATION OF HUMAN ADRENOCORTICAL CARCINOMA CELLS (NCI-H295R) ........ \\
\hline 3.16. & Cryopreservation...... \\
\hline 3.17 & RANSPORT INTO THE CELLS \\
\hline 3.18 & RADIOIMMUNOASSAY (RIA). \\
\hline 3.19 & XENOPUS LAEVIS OOCYTES. \\
\hline 3.19 .1 & Preparatiol \\
\hline 3.19 .2 & RNA. \\
\hline 3.19 .3 & Transport assay with Xenopus oocytes..... \\
\hline & RESULTS \\
\hline 4.1 & NE ADRENOCORTICAL PRIMARY CELLS. \\
\hline 4.1 .1 &  \\
\hline 1.2 & Inhibition of ${ }^{3} \mathrm{H}-\mathrm{PAH}$ uptake into bovine adrenocortical cells by probenecid........... \\
\hline & ins-stimulation of ${ }^{3} \mathrm{H}-\mathrm{PAH}$ uptake into bovine adrenocortical cells with $1 \mathrm{mM}$ \\
\hline
\end{tabular}


non-radioactive $\mathrm{PAH}$

4.1.4 Cis-inhibition of ${ }^{3} \mathrm{H}-\mathrm{PAH}$ uptake into bovine adrenocortical cells with non-radioactive PAH...........40

4.1.5 Cis-inhibition of ${ }^{3} \mathrm{H}$-PAH uptake into bovine adrenocortical cells with $1 \mathrm{mM}$ cortisol .......41

4.1.6 Cis-inhibition of ${ }^{3} \mathrm{H}$-PAH into bovine adrenocortical cells with $1 \mathrm{mM}$ glutarate ...............42

4.2 CIS-INHIBITION OF ROAT1-MEDIATED PAH UPTAKE BY CORTICOSTERONE ....................... 43

4.3 DEMONSTRATION OF A Na ${ }^{+}$-DICARBOXYLATE COTRANSPORTER IN

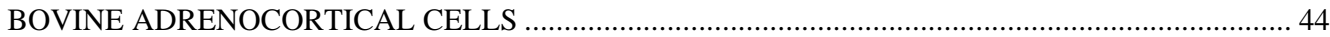

4.3.1

4.4

4.4.1

4.4.2

4.5

4.5.1

4.5.2

4.5.3

4.5.4

4.6

4.6.1

4.7

5

5.1

5.1.1

Cloning of an OAT-like organic anion transporter ......................................................48

Cloning of organic anion transporting polypeptide transporters (oatp)-like transporters ....50

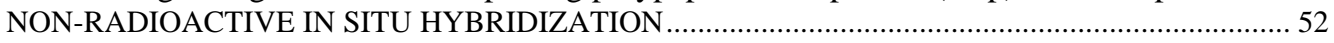

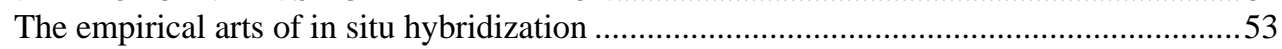

Expression pattern of the newly demonstrated organic anion transporters in the rat adrenal ............55

Localisation of oatp3 in rat kidney.....................................................................62

Hormone regulation of the expressed transporters in the adrenal gland ..........................63

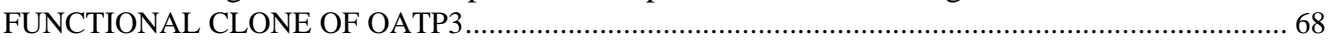

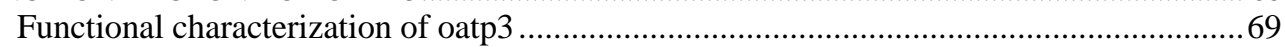

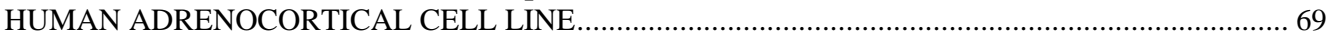

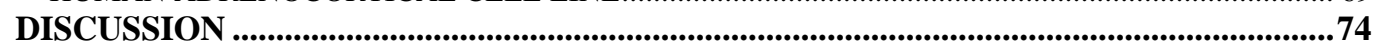

STEROID HORMONE RELEASE FROM BOVINE ADRECORTICAL CELLS ................................. 74

Demonstration and characterisation of a probenecid-inhibitable anion exchanger

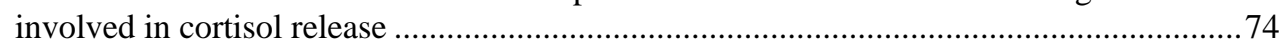

DEMONSTRATION OF A Na+-DICARBOXYLATE COTRANSPORTER IN

CORTICOSTERONE TRANSPORT VIA THE CLONED RAT ORGANIC ANION

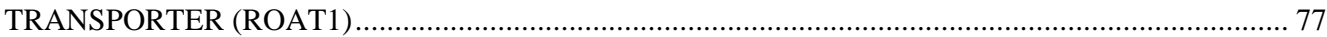

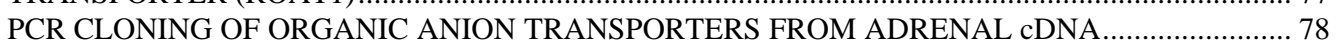

Rat renal organic anion transporter 1 (ROAT1) ........................................................ 78

Rat organic anion transporting polypeptide family (oatp)........................................... 79

LOCALISATION OF ROAT1 AND OATP1, OATP2 AND OATP3 IN RAT ADRENAL GLAND ...... 80

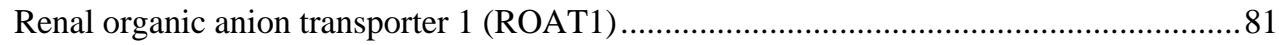

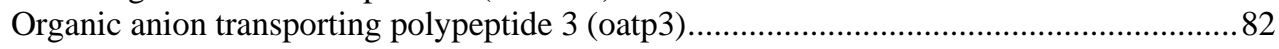

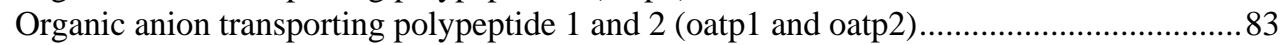

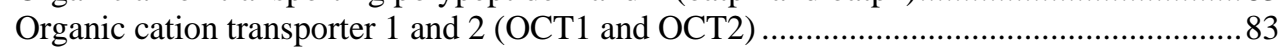



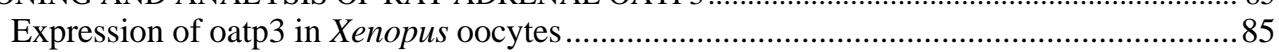

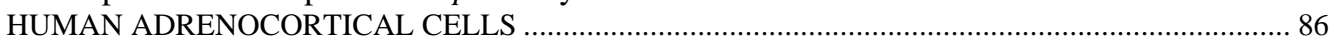



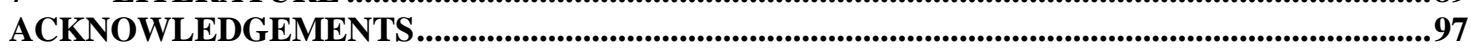

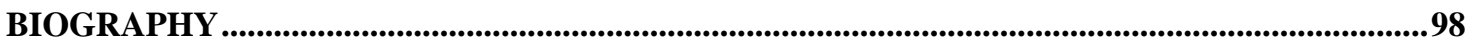




\section{ABSTRACT}

The adrenal steroid hormones have a central role in maintaining homeostasis, as they have influence on almost every physiological process. Their movement across the cell membrane is still poorly understood, although this is of great interest to basic biology and medicine. Previous studies have suggested transporter(s) may participate in this process. In this study the characteristic features of the previously demonstrated ROAT1-like exchange transport system in bovine adrenal cells were investigated with representative substrates. Corticotrophin (ACTH) stimulated ${ }^{3} \mathrm{H}-\mathrm{PAH}$ uptake into bovine adrenocortical cells, which could be inhibited by probenecid. Cortisol, glutarate and $\mathrm{PAH}$ in the incubation medium also cis-inhibited ${ }^{3} \mathrm{H}-\mathrm{PAH}$ uptake, and preincubation with PAH trans-stimulated ${ }^{3} \mathrm{H}-\mathrm{PAH}$ uptake. Preliminary studies on human adrenocortical cells also provided evidence for the existence of a probenecid inhibitable PAH-transporter. These results support the concept of an organic anion/dicarboxylate exchanger involved in cortisol release and PAH uptake into adrenocortical cells. Additionally, a sodium-dependent succinate uptake was also demonstrated in bovine adrenocortical cells. The uptake was inhibited by lithium, glutarate, fumarate, $\alpha$-ketoglutarate and maleate, but not by 2,3-dimethylsuccinate or cis-aconitate. The lack of inhibition by citrate on succinate uptake at $\mathrm{pH} 7.4$ is different from the data reported for the dicarboxylate transporters of all other organs investigated. These data are the first evidence for the existence of a $\mathrm{Na}^{+}$-dicarboxylate cotransporter in adrenocortical cells. The expression of two families of organic anion transporters in adrenal cells was also investigated. This study represents the first demonstration of the renal organic anion transporter (ROAT1) and the three members of the organic anion transporting polypeptide family (oatp1, oatp2, oatp3) by PCR from rat adrenal cDNA. The rat organic cation transporter 2 (OCT2) was also detected from the adrenal gland by in situ hybridization. In addition, in situ hybridization was performed to determine the localisation of the expression of the newly demonstrated transporters in the rat adrenal gland. In the case of ROAT1, intense signal was observed in the outer zona fasciculata, while oatp3 and OCT2 mRNAs were clearly shown to be expressed in the zona glomerulosa. The oatp1- and oatp2-specific probes produced signals in single cells or small groups of cells in the inner zona fasciculata and zona reticularis. For all transporters tested in the adrenal gland, only ROAT1 expression showed clear increase upon exposure to ACTH. The number of cells expressing ROAT1 mRNA was 
increased, especially in the inner zones of the adrenal cortex, while without ACTH, the signal was no longer detectable even in the inner zona fasciculata.. In summary these experiments provide clear evidence for the existence of a variety of transport systems in the adrenal gland. The evidence presented here suggests that of these transporters, the adrenal ROAT1 seems to be involved in glucocorticoid release from adrenocortical cells. 


\section{LIST OF ABBREVIATIONS}

bp

base pairs

${ }^{\circ} \mathrm{C}$

Celsius

cDNA

complementary DNA

cRNA

complementary RNA

DMSO

dimethyl sulfoxid

dNTP

deoxyribonucleotide phosphate

fNaDC-3

flounder sodium / dicarboxylate cotransporter 3

fROAT

flounder renal organic anion transporter

$\mathrm{h}$

hour

GAPDH

glyceraldehyde-3-phosphate dehydrogenase

hROAT1

human renal organic anion transporter 1

$\mathrm{K}_{\mathrm{m}}$

Michaelis Menten constant

LB

Luria Bertani broth

M

molar (moles per litre)

$\mu \mathrm{M}$

micromolar

$\mathrm{mM}$

millimolar

$\min$

minute

$\mathrm{ml}$

millilitre

mRNA

messenger RNA

oatp

organic anion transporting polypeptide

OCT

organic cation transporter

ORI

oocyte Ringer's solution

PAH

para-aminohippurate

ROAT1

rat renal organic anion transporter 1

rOCT1

rat organic cation transporter 1

rOCT2

rat organic cation transporter 2

PCR

polymerase chain reaction

rpm

revolution per minute

$\sec$

second

$\mathrm{U}$

unit

UTR

untranslated region 


\section{INTRODUCTION}

\subsection{THE ANATOMY OF THE ADRENAL GLAND}

In most mammalian species, including the rat, dog and human, the adrenal glands are paired organs, located close to the cephalic pole of the kidneys. The adrenals comprise two endocrine tissues which are embryologically and functionally distinct. The adrenal cortex which derives from the mesodermal lining of the coelom, and the adrenal medullary chromaffin tissue which originates in the neural crest and migrates into the centre of the cortical tissue during foetal development. The division of the mammalian adrenal cortex into three distinct concentric zones was first described by Harley in 1858, and the terms zona glomerulosa, zona fasciculata and zona reticularis were introduced by Arnold in 1866 (Neville \& O’Hare 1982).

Blood flows centripetally through the adrenal cortex into the large medullary sinusoids, which drain into the central vein. The arrangement of sinusoids within the gland is such that almost every cell of the adrenal cortex is in direct contact with a blood vessel. For many years it was the commonly held view that the nerve bundles passed through the cortex without branching. It is now widely accepted that the adrenal cortex receives a rich innervation, mainly in the region of the zona glomerulosa and the connective tissue capsule. A range of neurotransmitters has been identified in the adrenal cortex, including both catecholamines and neuropeptides (Kondo 1985, Vinson et al. 1994). Nerve terminals have been found in close contact with both blood vessels and the adrenocortical cells, and it has been shown that certain neurotransmitters are able to influence blood flow and steroid secretion in the adrenal gland (Vinson et al. 1994).

\subsection{HORMONES OF THE ADRENAL GLAND}

The principal secretory products of the adrenal medulla are the catecholamines, which are derivatives of the amino acid tyrosine, while the adrenal cortex secretes steroid hormones derived from cholesterol. The adrenal cortex is capable of producing about 50 different steroids with a wide range of activities. In most species, including the human, the most physiologically important of these corticosteroids are aldosterone, a mineralocorticoid, and cortisol, a glucocorticoid. The most abundant steroid produced 
by the adrenal cortex, however, is an androgen, dehydroepiandrosterone sulphate (DHEAS). The adrenal cortex also produces estrogen, progesterone, and a wide range of precursors and metabolites of these steroids. In rats, which lack the $17 \alpha$-hydroxylase activity necessary for cortisol and androgen production, the major glucocorticoid is corticosterone, and there is also a reduced androgen production. Recent evidence suggest that the mammalian adrenal cortex also produces an ouabain-like compound (Hinson et al. 1995).

\subsubsection{Steroid hormone biosynthesis}

The adrenal steroids are all synthesized from cholesterol, mainly by a series of hydroxylations involving the cytochrome P450 family enzymes. The major pathways of adrenal steroid biosynthesis are shown in Picture1.

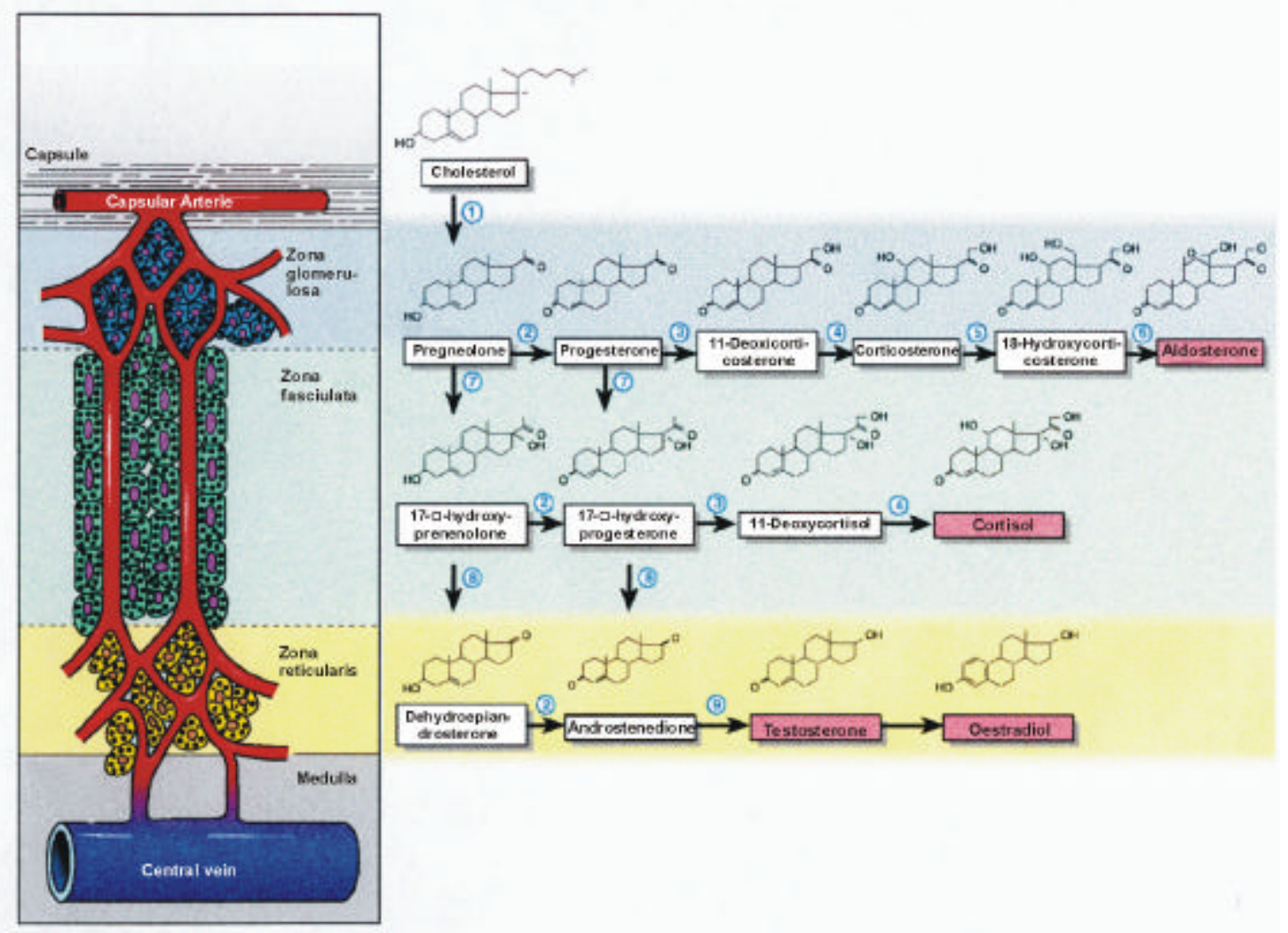

Picture 1. Pathways of steroid biosynthesis and the vasculature of the mammalian adrenal gland. The outermost layer of the adrenal cortex, immediately below the capsule, is the zona glomerulosa which produces mineralocorticoids (aldosterone).The zona fasciculata comprises the greater part of the adrenal cortex and produces glucocorticoids (cortisol). The innermost zone of the adrenal cortex is the zona reticularis which produces sex steroids (testosterone, estradiol). Key to enzymes: 1 cytochrome P450 ${ }_{\text {SCC }}$ (cholesterol side-chain-cleavage), $23 \beta$-hydroxysteroid dehydrogenase, 3 cytochrome $\mathrm{P}_{450} 0_{21}(21 \beta$ -

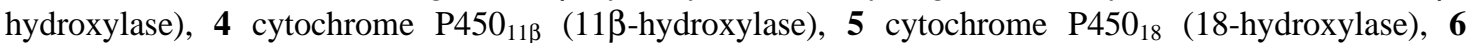
cytochrome $\mathrm{P} 450_{\text {aldo }}$ (aldosterone synthase), 7 cytochrome $\mathrm{P} 450_{17 \alpha / 17,20}$ lyase $(17 \alpha$-hydroxylase), 8 cytochrome $\mathrm{P} 450_{17 \alpha / 17,20 \text { lyase }}(17,20$-lyase), 9 17-reductase 
The cholesterol used in steroid synthesis is derived from two sources: de novo synthesis from acetate in the adrenals, or receptor-mediated uptake of plasma lipoproteins. Most cholesterol is stored in lipid droplets, in an esterified form, which is rapidly accessible in response to acute stimulation of steroidogenesis and is then replenished (Vinson et al. 1992). The endpoint of conversion of cholesterol to steroid hormones is zone-specific. In all mammalian species the zona glomerulosa is the only site of aldosterone synthesis. In rats the inner adrenocortical zones produce corticosterone as a major secretory product. In dog and human the inner zones favour the $17 \alpha$-hydroxy pathway, with the zona fasciculata mainly producing cortisol and the zona reticularis mainly producing androgenes and sulphated steroids.

\subsubsection{Regulation of adrenal function}

Glucocorticoid secretion is regulated almost exclusively by corticotrophin (ACTH), a 39 amino acid peptide hormone released by the anterior pituitary gland. Corticotrophin has several distinct effects on the adrenal gland, which are evident at different time intervals after stimulation. Acutely, ACTH causes an increase in the rate of blood flow through the adrenal gland and an increase in the rate of steroid secretion. The long term effects include stimulation of the growth of the adrenal cortex and increased expression of the enzymes involved in steroid biosynthesis (Simpson \& Waterman 1992). The adrenal gland requires a certain level of $\mathrm{ACTH}$ secretion to maintain its normal structure and function.

The regulation of aldosterone secretion is more complex, involving the interaction of several different systemic factors (for reviews see Müller 1988 and Vinson et al. 1992). Of these factors, the renin-angiotensin system is one of the most important, but very high concentrations of potassium ions can directly stimulate aldosterone secretion.

\subsubsection{Transport of hormones in blood}

The steroids secreted by the adrenal cortex, being hydrophobic in nature, are carried in the blood mostly bound to plasma proteins. Aldosterone is mostly carried by plasma albumin, while the glucocorticoids have a specific carrier protein, termed corticosteroidbinding globulin (CBG). There is a dynamic equilibrium between free and bound 
glucocorticoid in plasma, and it seems to be that the free steroid is biologically active (Mendel 1989).

\subsubsection{Actions of adrenal hormones}

The glucocorticoids and the mineralocorticoids bind to intracellular receptors resulting in induction of mRNA and protein synthesis. Steroid binding induces conformational changes in the receptor, leading to activation and transport into the nucleus, where the complex binds to the promoter of a variety of different genes. Glucocorticoids were named for their effects on carbohydrate metabolism, but they have a wide range of action in many tissues as a result of activation of specific glucocorticoid receptors. They have effects on intermediary metabolism, immune function, fluid and electrolyte balance, bone and connective tissue function, mood and behaviour, and developmental processes. Glucocorticoids have an antagonistic action on insulin in intermediary metabolism as they increase hepatic glycogenesis by activating glycogen synthase and inactivating glycogen phosphorylase (Stalmans \& Laloux 1979). They also increase hepatic gluconeogenesis by activation of glucose-6-phosphatase and pyruvate kinase and mobilisation of glucogenic substrates from peripherial tissues (Exton 1979). High glucocorticoid levels in the serum have prominent anti-inflammatory and immunosuppressive action, and thus glucocorticoids have an important role in the modulation and suppression of the acute stress response (Muck et al. 1984) and have pharmacological uses. However, their role in the normal modulation of immune processes is unclear. The effect on fluid and electrolyte balance is mediated via glucocorticoid receptors rather than an interaction with mineralocorticoid receptors (Gardner et al. 1986, Raff 1987). Glucocorticoids influence bone and mineral metabolism by reducing calcium absorption from the gut, resulting increased serum levels of parathyroid hormone, inhibiting osteoblast function and thus decreasing new bone formation (Hahn et al. 1979). In connective tissues, glucocorticoids inhibit the proliferation of fibroblasts and their production of collagen and glycosaminoglycans, resulting in impaired wound healing (Leibovich \& Ross 1975). Glucocorticoids affect a diverse range of processes such as sleep patterns, cognition, and the reception of sensory input (McEwen 1979) and they have at least a maintaining role in depressive disorder (Bearn \& Raven 1993), but the mechanism underlying these effects are poorly understood. 
The main function of mineralocorticoids is in the regulation of water and electrolyte balance. Their principal effect is to increase the reabsorbtion of sodium in the kidney and in secretory epithelia.

Finally, there are groups of steroid hormones, namely the neural active steroids, which do not act through the classical intracellular, genomic mechanism described above. For example, pregnenolone sulphate and DHEAS are potent GABA antagonists and positive allosteric modulators at the N-methyl-D-aspartate (NMDA) receptor in the brain (Mellon 1994).

Under normal physiological conditions the corticosteroids have a central role in maintaining homeostasis and under pathophysiological stress work towards restoring it. Also, where the glucocorticoids are employed as pharmacological agents, a correct understanding of their way to reach their target cells and their manifold influences on cellular processes is essential if adverse reactions are to be avoided or minimised.

\subsection{MOVEMENT OF STEROID HORMONES THROUGH THE PLASMA MEMBRANE}

The different biosynthetic pathways and the regulation of steroid hormone synthesis, and also their action on their target organs and cells have been well characterised in recent years. In contrast, the release of steroids from the steroid-synthesizing cells into the blood and their entry into the target cells is poorly understood. It has long been assumed that this occurs via simple diffusion or exocytosis, based on the lipophilic structure of steroid hormones. However, in vitro studies demonstrated retention of steroids against a concentration gradient at the plasma membrane (Whitehouse et al. 1971, Inaba et al. 1974) and direct morphological evidence for exocytosis or any relevant storage of cortisol has never been demonstrated (Gemmell et al. 1977, Basset et al. 1980). Therefore, it is possible that a transport mechanism is also involved in steroid hormone release.

\subsubsection{Transporter participation in cortisol uptake into hepatocytes}

One of the first reports suggesting the transporter-mediated uptake of glucocorticoids was published by Rao et al. in 1976. They found that the uptake of cortisol into isolated liver cells was temperature dependent, showed saturation kinetics, was inhibited by 
cortisone and corticosterone, and was significantly decreased by metabolic inhibitors and sulfhydryl reagents. The uptake was not dependent on sodium and was not affected by ouabain. The uptake from the external media into the liver cells was a rapid process, and showed characteristics of mediation by protein. Since the specific glucocorticoid binding proteins are localised in the cytoplasm in these cells, it suggests that these proteins are not directly involved in the uptake of cortisol. Their conclusion was that the transport of cortisol into the liver cells seemed to be in part a carrier-mediated action. However, a transport protein(s) mediating cortisol transport has yet to be identified.

\subsubsection{The multispecific organic anion transport system (OAT)}

One possible candidate for glucocorticoid transport is the organic anion transport system in the kidney. This multispecific system has been well characterised and has an important role in the excretion of potentially toxic organic anions, including endogenous compounds and their metabolites. The well characterised basolateral uptake step of this system involves exchange of an organic anion for an intracellular dicarboxylate, probably $\alpha$-ketoglutarate, via the OAT1 transporter. This process is functionally coupled to sodium-dicarboxylate cotransport which recycles the exchanged dicarboxylates into the cell, and the sodium ions are pumped out via the $\mathrm{Na}^{+}-\mathrm{K}^{+}-$ ATPase at the cost of one molecule of ATP (Fig. 1.). The model substrate for this system is para-aminohippurate, or PAH, a product of 4-aminobenzoate metabolism and its classical inhibitor is probenecid (Fig. 2.).

Although the functional characteristics of this organic anion system have been known for many years, the protein involved in the basolateral uptake of organic anions has only recently been identified, and is known as OAT1, from the rat and flounder kidney by functional expression in Xenopus laevis oocytes (Sekine et al.1997, Sweet et al.1997, Wolff et al. 1997). These proteins mediated PAH uptake, which was cis-inhibited by different kind of endogenous and exogenous organic anions and by dicarboxylates. From these observations it was suggested that these proteins moderate organic anion transport at the basolateral membrane of the proximal tubule of the kidney. During the present study, the human homologue was also cloned (Reid et al. 1998). 
Inhibition studies on PAH uptake in the proximal tubule of the rat kidney were carried out by Ullrich and coworkers in order to determine the structural requirements of substrates of the system. This transport system has wide substrate specificity with a necessity of a negative or partial negative charge on a hydrophobic backbone, but the system also interacts with non-ionisable hydrophobic compounds. The saturable transport of cortisol at physiological concentration was also shown by these studies, and this process was inhibited by probenecid (Ullrich et al. 1991). Recently it was demonstrated that adrenocorticotroph hormone (ACTH)-stimulated cortisol release from primary bovine adrenocortical cells was inhibited by probenecid and trans-stimulated by PAH (Steffgen et al. 1996 and Rohrbach et al. 1997). Furthermore, oocytes expressing adrenocortical mRNA transport PAH in a probenecid-inhibitable manner, the existence of mRNA encoding a PAH transporter in the adrenocortical cells.



Figure 1. Model of basolateral organic anion uptake in proximal tubule cells of the kidney. The current model for basolateral organic anion uptake involves import of an organic anion, represented here by $\mathrm{PAH}$, in exchange for an intracellular dicarboxylate $(\alpha-\mathrm{KG})$, by the multispecific organic anion transporting system (OAT1). The intracellular pool of $\alpha$-ketoglutarate is maintained by metabolism and import by sodium-dicarboxylate cotransporter (NaDC-3), which returns $\alpha$-ketoglutarate to the cell together with three sodium ions, in a process driven by the inwardly directed sodium gradient. $\mathrm{The}^{+}{ }^{+}$ $\mathrm{K}^{+}$-ATPase pumps the sodium ions from the cell to maintain the sodium gradient. 
a;

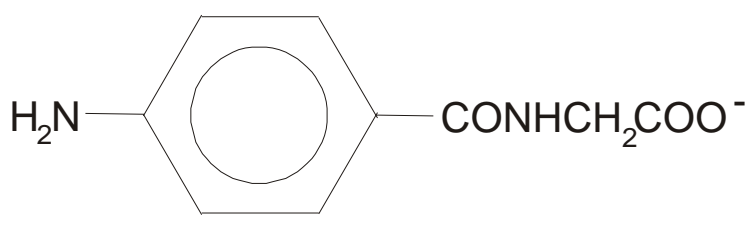

b; $\quad-O O C-\mathrm{CH}_{2}-\mathrm{CH}_{2} \mathrm{COO}-$

$\mathrm{c} ; \quad-\mathrm{OOC}-\mathrm{SO}_{2} \mathrm{~N}-\begin{aligned} & \mathrm{CH}_{2} \mathrm{CH}_{2} \mathrm{CH}_{3} \\ & \mathrm{CH}_{2} \mathrm{CH}_{2} \mathrm{CH}_{3}\end{aligned}$

Figure 2. The chemical structure of the main compounds interacting with the organic anion system a; para-aminohippurate, the model substrate of the multispecific organic anion transporting system b; $\alpha$-ketoglutarate, an intracellular exchange partner for organic anion uptake

c; probenecid, the classical inhibitor of the multispecific organic anion transporting system

\subsubsection{The multispecific organic anion transporting polypeptide family (oatp)}

Another candidate for steroid transport is the organic anion transporting polypeptide (oatp) family which represents a polyspecific transport system that can mediate chargeindependent uptake of a wide variety of structurally unrelated amphipathic compounds (Fig. 3.).

Based on the expression studies of cloned members of the oatp family, it appears that steroid hormones are one of their main substrates. The first member of this family (oatp1) was cloned from rat liver (Jacquemin et al. 1994, Kullak-Ublick et al. 1994), but is also expressed in the proximal tubules of the kidney and in the brain. This transporter when transiently expressed in HeLa cells mediates sodium-independent uptake of conjugated (taurocholate) and unconjugated (cholate) bile acids, and conjugated steroids with a negative charge on the D ring (e.g. 17 $\beta$-D-glucoronide, estrone-3-sulphate). Probenecid had a moderate inhibitory effect on the transporter, whereas PAH neither inhibited nor was transported (Kanai et al. 1996). The uptake of sulphobromophthalein (BSP), the model substrate of this transport system, was inhibited by corticosterone, but corticosterone was not transported by the transporter 
(Kanai et al. 1996). In oocytes other steroid hormones such as cortisol and aldosterone were significantly transported via oatp1 (Bossuyt et al. 1996).
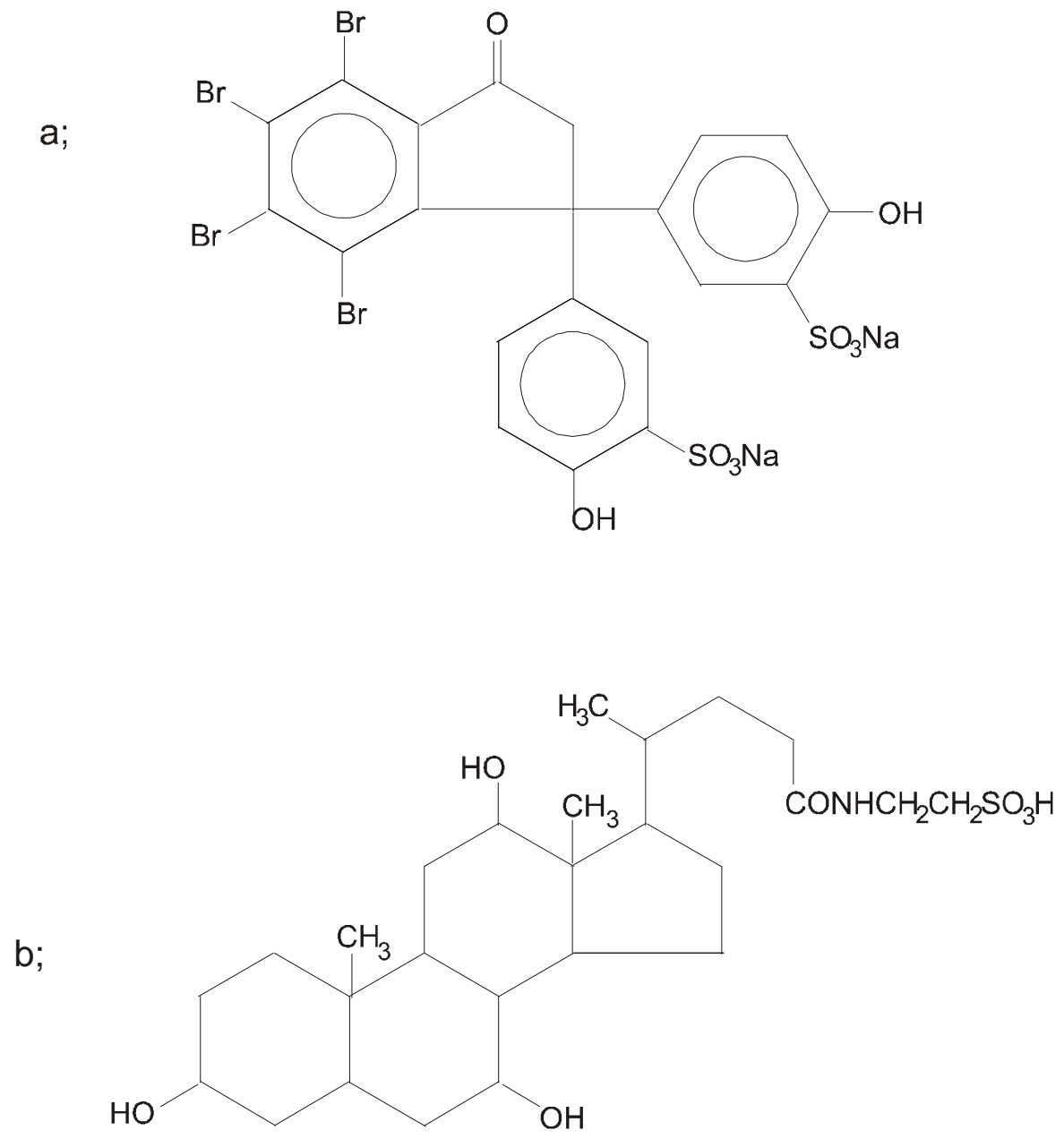

Fig. 3. The chemical structure of the main compounds interacting with the organic anion transporting polypeptide system.

a; sulfobromophthalein (BSP), the model substrate of the organic anion transporting polypeptide system b; taurocholate, conjugated bile acid and model substrate of the organic anion transporting polypeptide system

The second member of this family, called oatp2 was isolated from rat brain (Noé et al. 1997), but is also expressed in the liver. This transporter also transports conjugated and unconjugated bile acids, conjugated steroids, as well as digoxin, thyroid hormones (triiodothyronine, thyroxine) and the cardiac glycoside ouabain. Dehydroepiandrosterone sulphate (DHEAS), which is produced by the adrenal cortex was significantly transported via oatp2. In contrast, unconjugated steroids such as aldosterone, estradiol and testosterone, and PAH were not transported. 
The third member of this family (oatp3) was isolated from the rat retina, and is also present in the kidney (Abe et al. 1998). This transporter is less well characterised, but in common with the other members of this family it mediates sodium-independent uptake of conjugated and unconjugated bile acids, and thyroid hormones.

\subsection{THE AIM OF THE PRESENT STUDY}

The goal of this study was to test the hypothesis that steroid release from adrenocortical cells is, at least in part, carrier mediated. Three lines of investigation were chosen to achieve this aim. Firstly, the classical renal organic anion transport system, previously shown to be present in bovine adrenal glands, was to be further characterised in bovine adrenocortical cell culture. To demonstrate the putative expression of organic anion transporters in the adrenal cortex, primers were designed for PCR-based homology cloning using the sequence data of previously cloned transporters (OAT1 and oatp1, oatp2, oatp3). These amplified sequences were then to be used for in situ hybridisation experiments, to determine where these genes are expressed in the adrenal gland. Finally, a human cell model was established for future characterisation of glucocorticoid release from the human adrenal gland. 


\section{MATERIALS}

\subsection{CHEMICALS}

All chemicals used in this study were obtained from Sigma, Merk, Applichem, Serva, Roth, Bio Rad, Fluca, Amerscham, Gibco or Boehringer, unless otherwise stated in the text.

\subsection{ENZYMES}

Collagenase CLS II (Biochrom KG, Berlin, Germany)

Pfu DNA polymerase (Stratagene La Jolla, CA, USA)

PowerScript DNA polymerase (PAN Biotech $\mathrm{GmbH}$ )

Superscript (Gibco BRL Life Technologies)

Taq DNA polymerase (Promega $\mathrm{GmbH}$ )

T3 RNA polymerase (Promega $\mathrm{GmbH}$ )

T7 RNA polymerase (Promega $\mathrm{GmbH})$

Rnase H (Promega GmbH)

Trypsine (Gibco BRL )

Proteinase K (Boehringer Mannheim GmbH)

Hind III, XbaI, DnpI, NotI (MBI Fermentas Vilnius, Lithuania)

\subsection{BUFFERS}

Blocking reagent $10 \%$

(10 g Blocking-reagent powder (Boehringer Mainnheim $\mathrm{GmbH}$ ) in $100 \mathrm{ml}$ malic acid buffer (Boehringer Mannheim $\mathrm{GmbH}$ )

DEPC-water

$(0.1 \%$ (v/v) diethylpyrocarbonate into demanded amount of distilled water)

EDTA 0.5M (pH 8.0)

$\mathrm{MgCl}_{2} 1 \mathrm{M}$

$\mathrm{NaCl} 5 \mathrm{M}$

SDS $10 \%$

SOC medium (Gibco BRL Life Technologies) 
SSC buffer (Fluka Biochemika)

Tween-20 10\%

TBST 10x

(125 ml 1M Tris-HCl (pH 7.5), $45 \mathrm{~g} \mathrm{NaCl}, 500 \mu$ Tween-20 (10\%) DEPC-water was added to $500 \mathrm{ml}$ )

Tris-HCl 1M (pH 7.0, 8.0, 9.5)

Tris-Nacl-PVA buffer

(10 ml Tris-HCl 1M (pH 9.5), $2 \mathrm{ml} \mathrm{NaCl} \mathrm{5M,} 10 \mathrm{~g}$ 70-100 KD polyvinyl alcohol and DEPC-water was added to $100 \mathrm{ml}$ )

TEN-buffer

$(500 \mu \mathrm{l} 1 \mathrm{M}$ Tris-HCl pH 8.0, $100 \mu \mathrm{l}$ 0.5M EDTA pH 8.0, $1000 \mu \mathrm{l} 5 \mathrm{M} \mathrm{NaCl}$ and DEPCwater was added to $50 \mathrm{ml}$

Wash buffer I

$7.5 \mathrm{ml}$ 20x SSC buffer, $1.5 \mathrm{ml} 10 \%$ SDS and DEPC-water was added to $150 \mathrm{ml}$

Wash buffer II

$1 \mathrm{ml}$ 20x SSC buffer, $1 \mathrm{ml}$ 10\% SDS and DEPC-water was added to $100 \mathrm{ml}$

Blocking buffer

$5 \mathrm{ml} \mathrm{FCS,} 5 \mathrm{ml}$ 10\% Blocking reagent, $40 \mathrm{ml}$ 1x TBST buffer

Antibody solution

$5 \mu \mathrm{l} \mathrm{FCS,} 50 \mu \mathrm{l} 10 \%$ Blocking reagent, $1 \mu \mathrm{l}$ Anti-DIG antibody, $444 \mu \mathrm{l}$ 1x TBST buffer

NTM buffer

$2 \mathrm{ml} 5 \mathrm{M} \mathrm{NaCl}, 10 \mathrm{ml} 1 \mathrm{M}$ Tris- $\mathrm{HCl}$ (pH 9.5), $5 \mathrm{ml} 1 \mathrm{M} \mathrm{MgCl}_{2}$ DEPC-water was added to $100 \mathrm{ml}$

Painting solution

$1 \mathrm{ml}$ Tris-Nacl-PVA buffer, $5 \mu \mathrm{l} 1 \mathrm{M} \mathrm{MgCl}_{2} 18,6 \mu \mathrm{l}$ NBT/BCIP mixture (Boehringer)

In situ grade hybridisation buffer (Amersham Pharmacia Biotech Europe GmbH)

PBS buffer

(0.144 g/L KH $\left.\mathrm{PO}_{4}, 9 \mathrm{~g} \mathrm{NaCl}, 0.795 \mathrm{Na}_{2} \mathrm{HPO}_{4}-7 \mathrm{H}_{2} \mathrm{O}\right)$

\subsection{OLIGONUCLEOTIDES}

General PCR reactions for screening and sequencing of clones and incorporation of restriction sites were carried out with sequence-specific primers from NAPS (NAPS Göttingen $\mathrm{GmbH}$ ) or INTERACTIVA (INTERACTIVA Biotechnologie GmbH). All primers used are listed in Results. 


\section{$2.5 \quad$ KITS}

Nucleic acid purification:

QIAGEN RNA-DNA Maxi Kit (QIAGEN, Hilden, Germany)

Oligotex mRNA Mini Kit (QIAGEN)

QIAprep Spin Miniprep Kit (QIAGEN)

QIAquick $^{\mathrm{TM}}$ Spin Miniprep Kit (QIAGEN)

PCR purification Kit (QIAGEN)

Nucleotrap ${ }^{\mathrm{TM}}$ Extraction Kit (Macherey-Nagel, Düren, Germany)

NucleoSpin ${ }^{\mathrm{TM}}$ Extract 2 in 1 (Macherey-Nagel)

PCR cloning kits:

TOPO $^{\mathrm{TM}}$ TA Cloning Kit (Invitrogen, Carlsbad, CA, USA)

ZeroBlunt $^{\mathrm{TM}} \mathrm{TOPO}^{\mathrm{TM}}$ Cloning Kit (Invitrogen)

PCR-Script ${ }^{\mathrm{TM}}$ Amp Cloning Kit (Stratagene, La Jolla, CA, USA)

Mutagenesis:

QuickChange Site-directed Mutagenesis Kit (Stratagene)

cRNA synthesis:

T7 mMessage mMachine ${ }^{\mathrm{TM}}$ (Ambion, Austin, TX, USA)

\subsection{BACTERIA}

One Shot $^{\text {TM }}$ competent cell, TOP10F (Invitrogene Carlsbad, CA, USA)

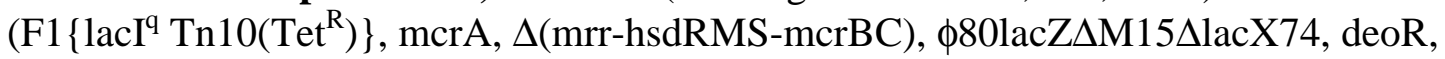
recA1, araD139, $\Delta$ ara-leu)7697, galU, galK, $\operatorname{rpsL}\left(\operatorname{Str}^{\mathrm{R}}\right)$, endA1, nupG)

\subsection{PLASMID VECTORS}

pPCR-Script vector (Strategene, La Jolla, CA, USA)

(CoIE1 origin, ampicillin resistance, 1 acZ reporter, T7 and T3 RNA polymerase promoters) 
pSPORT vector (Gibco BRL Life Technologies)

(pUC origin, ampicillin resistance, lacZ reporter and lacI repressor, T7 and SP6 RNA polymerase promoters)

\subsection{RADICHEMICALS}

Aminohippuric acid, P-[Glycyl-2- $\left.{ }^{3} \mathrm{H}\right] ;{ }^{3} \mathrm{H}-\mathrm{PAH}$

spec. activity: $5.0 \mathrm{Ci} / \mathrm{mmol}$, conc.: $1 \mathrm{mCi} / \mathrm{ml}$ (NEN Life Science, Boston, MA, USA)

Corticosterone, $\left[1,2,6,7-{ }^{3} \mathrm{H}(\mathrm{N})\right]-;{ }^{3} \mathrm{H}$-corticosterone

spec.activity: $83 \mathrm{Ci} / \mathrm{mmol}$, conc.: $1 \mathrm{mCi} / \mathrm{ml}$ (NEN Life Science)

Succinic acid, $\left[1,4-{ }^{14} \mathrm{C}\right]-,{ }^{14} \mathrm{C}$-succinate

spec.activity: $58.4 \mathrm{mCi} / \mathrm{mmol}$, conc.: $0.1 \mathrm{mCi} / \mathrm{ml}$ (NEN Life Science)

Taurocholic acid, $\left[24-{ }^{14} \mathrm{C}\right]-,{ }^{14} \mathrm{C}$-Taurocholate

spec. activity: $45.5 \mathrm{mCi} / \mathrm{mol}$, conc.: $0.02 \mathrm{mCi} / \mathrm{ml}$ (NEN Life Science)

\subsection{CELL LINES}

HCI-H295R (American Type Culture Collection, Manessas, VA, USA)

\subsection{CELL CULTURE MEDIA}

Dulbecco's modified eagle's medium (DMEM)

Dulbecco's modified eagle's medium nutrient mixture F-12 HAM (SIGMA)

(with L-glutamine and $15 \mathrm{mM}$ HEPES, without phenol red and sodium bicarbonate)

\subsection{CELL CULTURE MEDIA SUPPLEMENTS}

ITS $+{ }^{\mathrm{TM}}$ Premix (Becton Dickinson Labware)

$\mathrm{Nu}$-Serum (Becton Dickinson Labware)

Foetal calf serum 


\subsection{SEQUENCE ANALYSIS SOFTWARES AND ONLINE SEQUENCE}

GCG for various sequence analyses (Wisconsin)

Gene Runner for primer design

Chromas for sequence reading

MAP multiple aligment (http://genome.cs.mtu.edu/map.html)

Webcutter (http://www.medkem.gu.se/cutter/)

Blast (http://www.ncbi.nlm.nih.gov/BLAST/)

Entrez Pubmed (http://www.ncbi.nlm.nih.gov/Entrez/)

\subsection{EQUIPMENTS}

Automated DNA sequencer, ABI Prism, Applied Biosystems (Laguna Beach, CA, USA)

Balance, Sartorius (Göttingen, Germany)

Centrifuges: Biofuge fresco, Heraus (Ostrode, Germany)

5417R, Eppendorf (Hamburg, Germany)

1394, Hettich

C-1200, National Labnet Co

RC-5B, Sorvall (Newtown, CT,USA)

Circulating water bath, RCB 300, Hoefer

Dissection microscope, Stemi 1000, Zeiss (Jena, Germany)

Gel Chambers: Midi, MWG-Biotech (Ebersberg, Germany)

VEU 2001, Pharmacia (Uppsala, Sweden)

Gel documentation, Gel Print 2000 I, Biophotonics (Ann Arbor, MI, USA)

Heated magnetic stirrer, Privileg

Microwave, 8017, 8521, Privileg

Nanoliter injector, World Precision Instrument (Sarasota, FL, USA)

pH meter, pH-Meter 611, Orion Research Inc (Beverly, MA, USA)

Refrigerated aspirator, Unijet II, UniEquip (Martinsried, Germany)

Scintillation counter 1500 Tri-Carb, Packard

Speed vac concentrator, SVC 100E, Savant (Holbrook, NY, USA)

Spectrophotometer, GeneQuant II, Pharmacia (Uppsala, Sweden)

Thermocyclers: 2400, Perkin Elmer 
Omn-E HBTRE, Hybaid Ltd (Teddington, England)

PTC-200, MJ Research (Watertown, MI, USA)

UV transilluminator, TM40, UVP Inc (Upland, CA, USA)

Vortexer, REAX Top, Heidolph 


\section{METHODS}

\subsection{ISOLATION OF TOTAL RNA FROM RAT ADRENAL GLANDS}

Reagents:

rat adrenal glands

Qiagen Total RNA Midi Kit

$\beta$-mercaptoethanol

isopropanol

RNase-free water

formaldehyde- $-1.2 \%$ agarose gel

$52 \mathrm{ml}$ DEPC-water, $13.9 \mathrm{ml}$ 5x MOPS buffer, $0.83 \mathrm{~g}$ agar

Total RNA from male Wistar rat adrenal glands was prepared with Qiagen RNA-DNA Maxi kit according to the manufacturer's protocol. The adrenal glands were excised from $250 \mathrm{~g}$ Wistar rats. The fresh tissue (4 adrenals) was immediately taken into a $15 \mathrm{ml}$ polypropylene centrifuge tube containing $2 \mathrm{ml}$ QRL1 buffer $(10 \mu l \beta$-mercaptoethanol per $1 \mathrm{ml}$ lysis buffer was added before use). Homogenisation was performed instantly, to avoid RNA degradation, using rotor-stator homogenizer until the tissue was fully disrupted. To precipitate most of the proteins the lysate was mixed with $2 \mathrm{ml}$ QRV1 buffer and eliminated by centrifugation for $20 \mathrm{~min}$ at $15.000 \mathrm{x} \mathrm{g}$ at $4^{\circ} \mathrm{C}$. The supernatant was carefully aspirated into a new $15 \mathrm{ml}$ tube and $3.2 \mathrm{ml}$ ice-cold isopropanol were added and incubated $5 \mathrm{~min}$ on ice. To pellet the nucleic acids it was centrifuged for $30 \mathrm{~min}$ at $15.000 \mathrm{x} \mathrm{g}$ at $4^{\circ} \mathrm{C}$. During centrifugation the QIAGEN-tip was equilibrated with $3 \mathrm{ml}$ QRE buffer by allowing the column to empty by gravity flow. The pellet was resuspended and dissolved in $1 \mathrm{ml}$ QRL1 buffer ( $\beta$ mercaptoethanol was added). To create optimal conditions for binding RNA to QIAGEN resin the sample was diluted with $9 \mathrm{ml}$ QRV2 buffer and applied to the QIAGEN- column. It was allowed to enter the resin by gravity flow. Contaminants (proteins, polysaccharides, carbohydrates ...etc.) were washed away with $12 \mathrm{ml}$ QRW buffer. RNA was then specifically eluted with $6 \mathrm{ml}$ pre-warmed $\left(45^{\circ} \mathrm{C}\right) \mathrm{QRU}$ buffer into new $15 \mathrm{ml}$ centrifuge tube, while DNA remained bound. To precipitate the RNA 1 volume of ice-cold isopropanol was added, and after 10 min incubation on ice it was centrifuged for $30 \mathrm{~min}$ at $15.000 \mathrm{xg}$ at $4^{\circ} \mathrm{C}$. To wash the RNA pellet $5 \mathrm{ml} 70 \%$ ethanol 
was added and centrifuged for $15 \mathrm{~min}$ at $15.000 \mathrm{x} \mathrm{g}$ at $4{ }^{\circ} \mathrm{C}$. The supernatant was removed with care and the washing step was repeated. The RNA pellet was air dried for approximately $10 \mathrm{~min}$ and resuspended in $200 \mu \mathrm{l}$ Rnase-free water. The amount of RNA was measured by photometer and visualised on formaldehyde-1.2\% agarose gel. The gel was warmed up in a microwave until the agar was dissolved and it was then let to cool down and $3.7 \mathrm{ml}$ formaldehyde was added. The probe and the ladder RNAs were prepared as follows: $1 \mathrm{ng}$ RNA, $2 \mu \mathrm{l}$ 5x MOPS, $3.3 \mu \mathrm{l}$ formaldehyde and $10 \mu \mathrm{l}$ formamide. The reaction mix was then incubated for $15 \mathrm{~min}$ at $55^{\circ} \mathrm{C}$, then $5 \mu \mathrm{l}$ probe buffer and $1 \mu \mathrm{l}(1 \mu \mathrm{g} / \mu \mathrm{l})$ ethidium bromide were added. The probes were run in $350 \mathrm{ml}$ 1x MOPS buffer at $60 \mathrm{~V}$ for approximately 3 hours.

\subsection{ISOLATION OF MESSENGER RNA FROM TOTAL ADRENAL RNA}

Reagents:

mRNA isolation mini kit

Principle, the poly(A) tail of the mRNA binds with hybridisation to oligo(dT) molecule linked to latex particle while the other RNAs are washed away.

The total RNA solution $(0-250 \mu \mathrm{g})$ was made up to $360 \mu \mathrm{l}$ with DEPC-water, and $15 \mu \mathrm{l}$ pre-warmed $\left(37^{\circ} \mathrm{C}\right)$ oligotex suspension and $75 \mu \mathrm{l} 6 \mathrm{x}$ binding buffer were added to it. To disrupt the secondary structure of the RNA molecules the mixture was incubated 3 min at $65^{\circ} \mathrm{C}$. The hybridisation between the oligo $(\mathrm{dT})_{30}$ molecules and the poly $(\mathrm{A})$ parts of the mRNAs was occurred at room temperature $(10 \mathrm{~min})$. Afterwards the solution was centrifuged at maximum speed and the supernatant was carefully aspirated. The pellet (the mRNA molecules bound to the latex particles) was then resuspended in $400 \mu \mathrm{l}$ wash buffer and applied to a spin column. The column was centrifuged for $1 \mathrm{~min}$ at $1200 \mathrm{rpm}$, and the mRNA was washed again with $400 \mu \mathrm{l}$ wash buffer. The mRNA was eluated from the column in two steps $(20 \mu \mathrm{l}$ and $30 \mu \mathrm{l})$ with preheated $\left(80^{\circ} \mathrm{C}\right)$ elution buffer. The concentration was determined with photometer. 


\section{3 cDNA SYNTHESIS FROM ADRENAL mRNA}

The isolated mRNA was used as a template to generate first strand cDNA using Superscript II enzyme.

Reagents:

Oligo $(\mathrm{dT})_{12-18}$ primer $(500 \mu \mathrm{g} / \mathrm{ml})$

Superscript II enzyme

5x first stand buffer $\quad 250 \mathrm{mM}$ Tris- $\mathrm{HCl}(\mathrm{pH} 8.3), 375 \mathrm{mM} \mathrm{KCl}, 15 \mathrm{mM} \mathrm{MgCl}_{2}$

DTT $0.1 \mathrm{mM}$

dNTP $500 \mu \mathrm{M}$ each dATP, dTTP, dGTP, dCTP

DEPC-water

The following components were assembled into a nuclease free PCR tube: $1 \mu \mathrm{l}$ Oligo(dT) $)_{12-18}$ primer, 50-500 ng mRNA and DEPC-water to the volume $12 \mu \mathrm{l}$. The mixture was heated for $10 \mathrm{~min}$ at $70^{\circ} \mathrm{C}$ and chilled immediately on ice. Then $4 \mu \mathrm{l} 5 \mathrm{x}$ first strand buffer, $2 \mu 10.1$ M DTT, $1 \mu 110$ mM dNTP mix, $1 \mu \mathrm{l}$ (200 U) SuperScript II enyzme were added to the reaction. The reaction mix was incubated for $50 \mathrm{~min}$ at $42^{\circ} \mathrm{C}$ and the enzyme was then made inactive by heating for $15 \mathrm{~min}$ at $70^{\circ} \mathrm{C}$. To remove RNA complementary to the cDNA $1 \mu \mathrm{l}$ (2 U) Rnase $\mathrm{H}$ was added and incubated for 20 $\min$ at $37^{\circ} \mathrm{C}$.

\subsection{POLYMERASE CHAIN REACTION}

The polymerase chain reaction (PCR) is a quick and sensitive process for in vitro enzymatic amplification of a definite segment of DNA for which flanking sequence information is available. The reaction mix contains a fragment of double-stranded template DNA and two single-stranded oligonucleotide primers designed with homology to the 5' and 3' ends of the target sequence, deoxyribonucleoside triphosphates (dNTPs), a buffer and a thermostable DNA polymerase. The mixture is cycled many times (about 30) through temperatures that permit denaturation, primer hybridisation to the template, and synthesis to exponentially amplify a product of definite size and sequence. This results in approximately million-fold amplification of 
the defined DNA segment in the ideal case. The PCR products are then visualised on an adequate gel and examined for yield and specificity.

\subsubsection{Degenerate PCR}

Reagents:

template

degenerate 5' primer

degenerate 3 ' primer

dNTPs

10x PCR buffer

$\mathrm{MgCl}_{2}$

Polymerase enzyme

To clone OAT and the oatps from rat adrenal cDNA a homology cloning strategy was used. Primers were designed based on the nucleic acid sequence alignment of previously cloned members of the related OAT (fROAT, OAT1, hROAT1) and oatp (oatp1, oatp2, oatp3) families (Table 6. and 7.). The PCR mixture consisted of the following mixture: 5x PCR buffer, additional $2 \mathrm{mM} \mathrm{MgCl}_{2}, 20$ pmol of each primer, 10 mM dNTP mixture, $200 \mathrm{ng}$ cDNA and $5 \mathrm{U}$ Taq polymerase and nuclease free water to a volume of $50 \mu \mathrm{l}$. Amplifications were for 34 cycles of $94^{\circ} \mathrm{C}$ for $30 \mathrm{sec}, 56^{\circ} \mathrm{C}$ for $45 \mathrm{sec}$ and $72^{\circ} \mathrm{C}$ for $1-2 \mathrm{~min}$; followed by a final extension step of $72^{\circ} \mathrm{C}$ for $10 \mathrm{~min}$.

\subsubsection{High fidelity PCR}

The sequence of the examined clone for protein expression system has to be as close as possible to the sequence of the naturally expressed mRNA. Most of the polymerases used for PCR amplification have high productivity, but low fidelity. To maximise fidelity PCR was carried out with PowerScript, a proofreading polymerase. PowerScript has high polymerase fidelity and is less sensitive to changes in the concentration of cations, template and primers in the PCR mix. 
Reagents:

template

sequence-specific 5' primer

sequence-specific 3' primer

dNTPs

10x PCR buffer

5x Optizymed enhancer

$\mathrm{MgCl}_{2}$

PowerScript DNA polymerase

The amplification with PowerScript was carried out as per the manufacturer's instructions (PAN system), with 25 cycles of the following amplification parameters: $94^{\circ} \mathrm{C}$ for $20 \mathrm{sec}, 55-60^{\circ} \mathrm{C}$ for $20 \mathrm{sec}$ and $68^{\circ} \mathrm{C}$ for $5 \mathrm{~min}$; followed by a final extension period of $10 \mathrm{~min}$ at $70{ }^{\circ} \mathrm{C}$. The full-length cDNA was cloned into pSPORT vector, and the fidelity of the polymerase enzyme was confirmed by sequencing.

\subsection{SITE DIRECTED MUTAGENESIS}

In vitro mutation of targeted nucleotides allows correction of errors introduced by PCR amplification, amino acid exchanges and generation or disruption of restriction enzyme recognition sites. The Quick-Change ${ }^{\mathrm{TM}}$ Site-Directed Mutagenesis Kit is based on PCR technique as the $P f u$ polymerase copies the entire plasmid clone from two complementary primers, both of which contain the mutation. The template plasmids are removed by digestion with a methylation-dependent endonuclease, DpnI, which reacts only with the methylated plasmids produced by bacteria (the target sequence is $5^{\prime}-\mathrm{G}^{\mathrm{m} 6}$ ATC-3'). The mutant plasmids with nicks can be transformed into E.coli, where the nicks are repaired.

Reagents:

Quick-Change ${ }^{\mathrm{TM}}$ Site-Directed Mutagenesis Kit

Oligonucleotide primers

DpnI restriction enzyme

Competent cells

SOC medium 
The primer pairs for site-directed mutagenesis were designed to anneal to the same sequence on opposite strands of the template plasmid containing the desired mismatch(s). The mutation was positioned possibly to the middle of the primer, with at least 12 bases of perfectly annealing sequence on both sides. The annealing temperature of the primers was about $75-80^{\circ} \mathrm{C}$, each primer had $\mathrm{GC}$ content of at least $40 \%$, and terminated in $\mathrm{G}$ or $\mathrm{C}$ bases. The reaction mix consisted of $50 \mathrm{ng}$ template plasmid, $5 \mu \mathrm{l}$ of 10x reaction buffer, $1 \mu \mathrm{l}$ of the dNTP mix, $125 \mathrm{ng}$ of each primer, $1 \mu \mathrm{l}$ of $P f u$ DNA polymerase $(2.5 \mathrm{U})$ and nuclease free water to $49 \mu \mathrm{l}$. Cycling parameters were: $95^{\circ} \mathrm{C}$ for $30 \mathrm{sec}, 55^{\circ} \mathrm{C}$ for $1 \mathrm{~min}$ and $68^{\circ} \mathrm{C}$ for $2 \mathrm{~min} / \mathrm{kb}$ of plasmid length for 12 (for point mutation) or 16-18 (for two or more mutations) cycles. The reaction mix was incubated with $1 \mu \mathrm{l} D p n \mathrm{I}$ enzyme for 2 hours at $37^{\circ} \mathrm{C}$ to remove the template plasmid. The efficiency of the extension was checked on agarose gel. The mutant plasmid was transformed into One Shot competent cells as described in 3.12.2.

\subsection{RESTRICTION DIGESTION}

The restriction enzymes are bacterial enzymes that recognise specific 4-8 base pair nucleotide sequences called restriction sites, and then cleave both DNA strands at this site, generating a reproducible set of fragments.

To restrict the template DNA with the adequate restriction enzyme $100 \mathrm{ng}-5 \mu \mathrm{g}$ DNA, 1-5 U/ $\mu \mathrm{g}$ DNA restriction enzyme and $10 \% \mathrm{v} / \mathrm{v}$ enzyme specific restriction buffer was mixed and incubated 1-3 hours, depending on degree of digestion required.

\subsection{LIGATION}

Restriction enzymes generating fragments that have a single-stranded "tail" called sticky-end, at both ends. The tails on the fragments generated at a given restriction site are complementary to those on all other fragments generated by the same restriction enzyme. DNA ligase can insert DNA restriction fragments into replicating DNA molecules producing recombinant DNA.

Sticky-end ligation of restricted pSPORT vector and oatp3 clone was carried out using T4 DNA ligase. The standard insert to vector ratio was 3:1 and the reaction consisted of 
$1 \mathrm{U}$ ligase $/ \mu \mathrm{g}$ DNA and $10 \mu \mathrm{l}$ 1x ligation buffer $(66 \mathrm{mM}$ Tris- $\mathrm{HCl}, 5 \mathrm{mM} \mathrm{MgCl}, 1 \mathrm{mM}$ dithioerythritol, $1 \mathrm{mM}$ ATP, $\mathrm{pH}$ 7.5). Following at least 16 hours incubation at $4^{\circ} \mathrm{C}$ the reaction mix was used to transform One Shot competent cells.

\subsection{AGAROSE GEL ELECTROPHORESIS}

Agarose gel electrophoresis was used to visualise and isolate DNA molecules following PCR amplification or restriction digestion. Agarose (0.8-2\%) was dissolved in TBE buffer (45 mM Tris, $45 \mathrm{mM}$ borate, $1 \mathrm{mM}$ EDTA) by heating in a microwave. After cooling $2 \mu \mathrm{l}$ of a $10 \mathrm{mg} / \mathrm{ml}$ ethidium bromide solution was added per $100 \mathrm{ml}$ gel and the gel was poured. Gels were routinely run at $80-100 \mathrm{~V}$ for $1-2$ hours, depending on the size of the examined DNA fragment or on the degree of band separation required.

\subsection{GEL EXTRACTION}

The DNA fragment was excised from the agarose gel and 3 volumes of binding and solubilization buffer (QB) was added to 1 volume of gel. It was incubated at $50^{\circ} \mathrm{C}$ until the gel slice was completely dissolved. To bind DNA, the solution was added to the QIAquick column and centrifuged at $13000 \mathrm{rpm}$ for $1 \mathrm{~min}$. During the DNA absorption step, useless primers, enzymes, nucleotides, agarose and ethidium bromide were not bound to the silica membrane. For direct sequencing and in vitro transcription the column was washed again with QB buffer. Salts were washed away by the ethanolcontaining PE buffer. If the DNA was used for salt sensitive application, such as bluntend ligation and direct sequencing, the column was incubated for 5 min with PE buffer, before centrifuging. Any residual PE buffer was removed by an additional centrifugation step. The DNA was eluted by centrifuging the column for $1 \mathrm{~min}$ at maximum speed with $50 \mu \mathrm{l}$ EB buffer (10 mM Tris-Cl, $\mathrm{pH} 8.5)$ or $\mathrm{H}_{2} \mathrm{O}(\mathrm{pH}$ 7.0-8.5).

\subsection{PCR PURIFICATION}

To 1 volume of the PCR reaction 5 volumes of binding buffer (PB) were added and applied to the QIAquick column and centrifuged at $13000 \mathrm{rpm}$ for $1 \mathrm{~min}$. During the DNA absorption step, unimportant primers, enzymes, nucleotides, and ethidium 
bromide were not bound to the silica membrane. Salts were washed away by centrifuging with ethanol containing PE buffer, and the remains of the wash buffer was cleared away by another centrifugation step. The DNA was eluted by centrifuging the column for $1 \mathrm{~min}$ at maximum speed with $50 \mu \mathrm{EB}$ buffer (10 mM Tris-Cl, $\mathrm{pH} 8.5)$ or $\mathrm{H}_{2} \mathrm{O}(\mathrm{pH} 7.0-8.5)$.

\subsection{NON-RADIOACTIVE TERMINAL CYCLE SEQUENCING OF DNA (SANGER 1977)}

Terminal cycle sequencing is a method of dideoxy sequencing in which the template DNA molecules are repetitively utilized to produce a sequencing ladder. The sequencing reaction mixture (consisting of template, specific primer, dNTP, fluorescence labeled 2',3'-dideoxynucleoside triphosphates (ddNTPs), and a termostable DNA polymerase) is subjected to repeated rounds of denaturation, annealing, and synthesis steps, similar to PCR. This method utilizes the ability of the DNA polymerase to apply ddNTPs as substrate. This 2',3'-dideoxynucleoside analog which lacks a 3' hydroxyl group, incorporated at the 3'end of the growing chain terminates the elongation. The amplified fragments were separated with electrophoresis and from the multiband pattern a computer program can assemble the sequence.

Reagents:

Premix

DNA template

primer

$\mathrm{dH}_{2} \mathrm{O}$

sequence loading buffe
Tris/HCl, phosphatase, Taq DNA polymerase, $\mathrm{MgCl}_{2}$, dNTPs, ddNTPs(fluorescence marked) ssDNA $(0.1 \mu \mathrm{g})$, dsDNA $(0.2-0.5 \mu \mathrm{g}), \mathrm{PCR}$ product(10-200 ng)

4 pmol

to $20 \mu \mathrm{l}$

$3 \mu$ formamid / 25 mM EDTA pH $8.0(5: 1)$

The reaction consisted of $4 \mu \mathrm{l}$ premix, 4 pmol sequence specific primer, DNA template and nuclease free water to $20 \mu \mathrm{l}$. The following PCR program was used: $94^{\circ} \mathrm{C}$ for 30 $\mathrm{sec}, 50^{\circ} \mathrm{C}$ for $10 \mathrm{sec}$, and $60^{\circ} \mathrm{C}$ for $4 \mathrm{~min}$. After 25 cycles, the amplified DNA was precipitated with an ethanol containing mixture $(250 \mu \mathrm{l} 100 \%$ EtOH $(\mathrm{RT}), 10 \mu \mathrm{l} 3 \mathrm{M}$ 
$\mathrm{NaAc} \mathrm{pH} 4.6,80 \mu \mathrm{l} \mathrm{H}_{2} \mathrm{O}$ ) by centrifugation at $15.000 \mathrm{rpm}$ for $15 \mathrm{~min}$. The pelleted DNA was vacuum dried and diluted with sequence loading buffer. The separation of the DNA fragments was made by electrophoresis in a $0.4 \mathrm{~mm}$ thick $5 \%$ polyacrilamide gel. The sequence was assembled and analyzed with various software packages and online providers, as listed in 2.12 .

\subsection{CLONING OF AMPLIFIED PRODUCTS}

Depending on the polymerase used for amplification, different vectors and methods were used to clone PCR products. Bacteria transformed with vectors containing the lac $\mathrm{Z}$ reporter gene were screened by blue-white selection. When no insert is present, a functional $\alpha$-peptide is produced that complements the gene product of lac $\mathrm{Z}$ to produce a functional $\beta$-galactosidase protein. When plated on indicator plates containing IPTG and $\mathrm{X}$-gal, the colonies are blue. When a cloned insert interrupts the lac Z gene, no complementation occurs and colonies appear white.

\subsubsection{TOPO TA Cloning}

Taq polymerase has a terminal transferase activity, which adds a single deoxyadenosine (A) to the 3' end of PCR products. TOPO Cloning ${ }^{\mathrm{TM}}$ exploits the ligation activity of topoisomerase by providing an activated, linearized vector, which has a single, overhanging 3' deoxythimidine (T) residue. Ligation occurs spontaneously within 5 min at room temperature. The pCR 2.1 TOPO vector allows blue-white selection of transformants.

Reagents:

pCR 2.1 TOPO vector $10 \mathrm{ng} / \mu \mathrm{l}$ in $50 \%$ glycerol, $50 \mathrm{mM}$ Tris- $\mathrm{HCl}(\mathrm{pH} 7.4), 1 \mathrm{mM}$ EDTA, $1 \mathrm{mM}$ DTT, $0.1 \%$ Triton X-100, $100 \mu \mathrm{g} / \mathrm{ml}$ BSA, phenol red

SOC medium $\quad 2 \%$ Tryptone, $10 \mathrm{mM} \mathrm{NaCl}, 2.5 \mathrm{mM} \mathrm{KCl}, 10 \mathrm{mM} \mathrm{MgCl}$, $10 \mathrm{mM} \mathrm{MgSO} 4,20 \mathrm{mM}$ glucose, $0.5 \%$ Yeast extract

One Shot ${ }^{\mathrm{TM}}$ competent cells 
In general, 0.5 to $2 \mu \mathrm{l}$ of PCR sample (10 ng $/ \mu \mathrm{l}$ ) provides the proper insert to vector ratio for TOPO Cloning ${ }^{\mathrm{TM}}$. The ligation reaction was carried out in $5 \mu$ l volume with 0.5-2 $\mu 1$ PCR product, nuclease free water to $4 \mu \mathrm{l}$ and $1 \mu \mathrm{l}$ pCR 2.1 TOPO vector. The reaction mixture was mixed gently and after incubation for 5 minutes at room temperature $\left(\sim 25^{\circ} \mathrm{C}\right)$ it was placed immediately on ice. To a $50 \mu \mathrm{l}$ vial of competent cells $2 \mu$ ligation reaction was added for transformation.

\subsection{2 $\quad$ PPCR-Script ${ }^{\mathrm{TM}}$ Amp cloning}

Blunt-end PCR products generated by proof-reading polymerases can be ligated in pPCR-Script vector, using the pPCR-Script ${ }^{\mathrm{TM}}$ Amp cloning kit. The kit increase the efficiency of blunt-end ligation by inclusion of SrfI restriction enzyme during the ligation step as in the case of intramolecular vector ligation, the end of the vector form the restriction site for SrfI enzyme. The pPCR Script vector allows blue-white selection of transformants.

Reagents:

pPCR Script vector pPCR Script reaction buffer SrfI restriction enzyme rATP

T4 DNA ligase One Shot ${ }^{\mathrm{TM}}$ competent cells SOC medium
$10 \mathrm{ng} / \mu \mathrm{l}$ composition not provided by manufacturer $5 \mathrm{U} / \mu \mathrm{l}$ $10 \mathrm{mM}$ $4 \mathrm{U} / \mu \mathrm{l}$

The molar ratio of insert to vector for successful ligation was calculated using the following formula:

$n g$ of insert $=\underline{(\text { size of the insert in } b p) \times(n g \text { of } p P C R \text { Script vector }) \times \text { molar ratio }}$ size of pPCR Script vector (2961 bp)

The manufacturers recommend an insert to vector ratio of between 40:1 and 100:1. The ligation reaction consisted of the following components: $0.5 \mu \mathrm{l}$ of pPCR Script vector, $1 \mu \mathrm{l}$ pPCR Script 10x reaction buffer, $0.5 \mu \mathrm{l}$ rATP, 4-6.4 $\mu$ l insert DNA, $0.8 \mu \mathrm{l}$ SrfI restriction enzyme, $0.8 \mu \mathrm{T}$ T4 DNA ligase and nuclease free water to $10 \mu \mathrm{l}$. The reaction mix was incubated for 1 hour at room temperature, then heated for $10 \mathrm{~min}$ at 
$65^{\circ} \mathrm{C}$ to inactivate the enzymes, and stored on ice. For transformation $2 \mu$ l ligation reaction was added to a $50 \mu \mathrm{l}$ vial of competent cells.

\subsubsection{One Shot ${ }^{\mathrm{TM}}$ Transformation Reaction}

After the One Shot cells were dissolved on ice, $2 \mu$ of the ligation reaction was added into the vial and incubated on ice for 30 minutes. The cells were exposed to heat shock at a $42^{\circ} \mathrm{C}$ water bath for 30 seconds without shaking and then transferred immediately to ice. After 2 minutes incubation on ice, $250 \mu \mathrm{l}$ room temperature SOC medium was added to the cells. The tube was shaken horizontally at $37^{\circ} \mathrm{C}$ for at least 1 hour for ampicillinlkanamycin selection, then placed on ice. From the transformation $100 \mu 1$ was spread on a pre-warmed LB agar plate and was incubated overnight at $37^{\circ} \mathrm{C}$.

\subsubsection{Analysis of Positive Clones with PCR}

A PCR cocktail consisting of PCR buffer, dNTPs, primers (M13 F and M $13 \mathrm{R}$ ) and Taq polymerase was prepared. White colonies were picked and analysed individually with a 25 cycles PCR $\left(94^{\circ} \mathrm{C}\right.$ for $45 \mathrm{sec}, 54^{\circ} \mathrm{C}$ for $30 \mathrm{sec}$ and $72^{\circ} \mathrm{C}$ for $1 \mathrm{~min}$ with a final incubation for $10 \mathrm{~min}$ at $72^{\circ} \mathrm{C}$ ). The PCR products were visualized on a $2 \%$ agarose gel with ethidium bromide. The positive colonies were cultured overnight in LB medium containing $50 \mu \mathrm{g} / \mathrm{ml}$ ampicillin or kanamycin.

\subsubsection{Plasmid isolation}

Plasmid DNA was isolated from the overnight cultures according to the manufacturer's instructions (Qiagen). Bacteria were lysed under alkaline conditions with P2 buffer, and the lysate was neutralized and adjusted to high-salt binding condition with N3 buffer. Afterwards the solution was centrifuged at maximum speed for 10 minutes, till a compact white pellet was formed. The supernatant was applied for purification to the QIAprep silica-gel membrane. Salts were wash away by centrifuging with ethanol containing PE buffer, and the remains of the wash buffer was cleared away by another centrifugation step. The DNA was eluted by centrifuging the column for $1 \mathrm{~min}$ at maximum speed with $50 \mu \mathrm{l}$ EB buffer (10 mM Tris-Cl, $\mathrm{pH} 8.5)$ or $\mathrm{H}_{2} \mathrm{O}(\mathrm{pH}$ 7.0-8.5). 


\subsubsection{LB Medium and Plates}

The LB medium consisted of $10 \mathrm{~g}(1.0 \%)$ Tryptone, $5 \mathrm{~g}(0.5 \%)$ yeast extract, $10 \mathrm{~g}$ $(1.0 \%) \mathrm{NaCl}$ and $\mathrm{H}_{2} \mathrm{O}$ to $950 \mathrm{ml}$. The $\mathrm{pH}$ of the solution was adjusted to 7.0 with $\mathrm{NaOH}$ and the volume was brought up to 1 litre, and autoclaved on liquid cycle for 20 minutes at 15 psi. It was then stored in the fridge.

For LB agar plates $15 \mathrm{~g} / \mathrm{L}$ agar was added to LB medium before autoclaving. After autoclaving, it was cooled down to about $55^{\circ} \mathrm{C}$, and antibiotic $(50 \mu \mathrm{g} / \mathrm{ml}$ of either ampicillin or kanamycin) was added before pouring into $10 \mathrm{~cm}$ plates. The plates were then stored in the fridge in the dark.

Before use for blue-white selection, the plates were warmed up to $37^{\circ} \mathrm{C}$ and $15 \mu 14 \%$ X-GAL, $4 \mu 1100 \mathrm{mM}$ IPTG in $181 \mu \mathrm{l}$ sterile water was pipetted onto the plate, and spread with a sterile spreader. The solution was allowed to diffuse into the plate by incubating at $37^{\circ} \mathrm{C}$ for a half an hour.

\subsection{NON-RADIOACTIVE IN SITU HYBRIDIZATION ON PARAFFIN EMBEDDED MATERIAL}

\subsubsection{Generation of riboprobes}

RNA probes of the different transporters were produced by a modified protocol using PCR generated templates for in vitro transcription. Briefly, PCR products were cloned into pPCR-Script vectors, which were used as a template for another PCR using oligonucleotide primers specific for the $\mathrm{T} 3-$ and $\mathrm{T} 7$ promoter regions of the plasmids. The PCR reaction mixture $(50 \mu \mathrm{l})$ contained $200 \mathrm{ng}$ plasmid DNA, 20 pmol of each primer, $1 \mu \mathrm{l}$ dNTP mixture (10 mM each), $5 \mu \mathrm{l} \mathrm{Taq}$ buffer and $2.5 \mathrm{U}$ Taq polymerase. After an initial $94^{\circ} \mathrm{C}$ denaturation step ( $2 \mathrm{~min}$.), 30 cycles were carried out at $94^{\circ} \mathrm{C}(45$ $\mathrm{sec}), 55^{\circ} \mathrm{C}(30 \mathrm{sec})$ and $72^{\circ} \mathrm{C}(1 \mathrm{~min})$, followed by a final extension step of $72^{\circ} \mathrm{C}(10$ min). The PCR products were visualised on a $1 \%$ agarose gel with ethidium bromide, excised and purified using QIAquick Gel Extraction kit. Digoxigenin-11-uridinetriphosphate (DIG-UTP) labelled sense and antisense probes were generated by in vitro transcription. Purified T3 or T7 PCR product was used as a template using either T3- or T7-polymerase, both according to the manufacturer's instructions. For the digoxigenin marking the following reaction mix was assembled: $200 \mathrm{ng}$ sample with DEPC water 
added to the final volume $9 \mu \mathrm{l}, 2 \mu \mathrm{l}$ DigRNA-label-mix, $4 \mu$ l transcription buffer, $2 \mu \mathrm{l}$ DDT, $1 \mu$ RNase inhibitor and $2 \mu 1$ polymerase. After 2 hours incubation at $37^{\circ} \mathrm{C}$ the RNA was precipitated with $2.5 \mu \mathrm{l}(4 \mathrm{M}) \mathrm{LiCl}$ and $75 \mu \mathrm{l}(100 \%) \mathrm{EtOH}$ overnight at $-20^{\circ} \mathrm{C}$. On the next day the reaction mix was centrifuged for 30 minutes at full speed (1300 rpm) and after washing with $70 \% \mathrm{EtOH}$ it was suspended in $20 \mu \mathrm{l}$ DEPC water. The amount of transcripts was monitored on $1 \%$ agarose gel.

\subsubsection{Non-radioactive in situ hybridisation}

Reagents:

Proteinase K

$14 \mathrm{mg} / \mathrm{ml}$

acetic anhydride

deionised formamide

5-bromo-4-chloro-3-indolyl phosphate (BCIP)

$50 \mathrm{mg} \mathrm{ml}$

nitroblue tetrazolium salt (NTB)

$75 \mathrm{mg} / \mathrm{ml}$

The buffers are listed in 2.3

Adrenals and kidney were taken from Wistar rats, fixed in $4 \%$ paraformaldehyde, and embedded in paraffin. In situ hybridisation was performed according to the method described by Breitschopf et al. 1992. To describe briefly, tissue sections were deparaffinised with Roticlear (Carl Roth $\mathrm{GmbH})$, hydrated in serial dilutions of ethanol $(100 \%, 90 \%$ and $70 \%)$ and postfixed in $4 \%$ TBS buffered paraformaldehyde. Samples were permeabilised using proteinase $\mathrm{K}(10 \mu \mathrm{g} / \mathrm{ml})$ for $30 \mathrm{~min}$ at $37^{\circ} \mathrm{C}$. Digestion was stopped by washing the samples in PBS ( $\mathrm{pH}$ 7.4). To block the endogenous alkaline phosphatase slides were incubated with $0.25 \%$ acetic anhydride and dehydrated in serial dilutions of ethanol (70\%, 90\% and 100\%). Digoxigenin labelled riboprobes were diluted 1:100 in hybridisation buffer. After application of sense and antisense probes the slides were covered with sterile cover slips and placed on a hot plate for $5 \mathrm{~min}$ at $85^{\circ} \mathrm{C}$ to denature the ribonucleotids. Hybridisation was performed overnight at $55-58^{\circ} \mathrm{C}$ in a sealed humidified chamber containing $50 \%$ formamide. Non-specific bound or unbound probes were removed by the following post-hybridisation washes: $1 \mathrm{x}$ $\mathrm{SSC} / 0.1 \% \mathrm{SDS}$ at room temperature $(2 \mathrm{x} 5 \mathrm{~min})$ and $0.2 \mathrm{x} \mathrm{SSC} / 0.1 \% \mathrm{SDS}$ at hybridisation temperature $(2 \times 10 \mathrm{~min})$. Finally, the sections were washed in TBS containing $0.1 \%$ Tween-20. DIG-labelled RNA probes were detected, after 
hybridisation to target nucleic acid, by enzyme linked immunoassay using an antibodyconjugate (anti-digoxigenin alkaline phosphatase). A subsequent enzyme catalysed colour reaction with 5-bromo-4-chloro-3-indolyl phosphate (BCIP) and nitroblue tetrazolium salt (NTB) were produced an insoluble blue precipitate, which visualised hybrid molecules.

\subsection{4 cRNA synthesis}

The T7 mMESSAGE mMACHINE kit enables the in vitro synthesis of large amount of cRNA from linear cDNA template, by incorporation of a 7-methyl guanosine cap analogue $\left(\mathrm{m} 7 \mathrm{G}\left(5^{\prime}\right) \mathrm{ppp}\left(5^{\prime}\right) \mathrm{G}\right)$ during polymerisation.

Reagents:

10x Transcription buffer

2x Ribonucleotide mix

10x Enzyme mix

template DNA

DNaseI

precipitation solution composition not provided by manufacturer

10 mM ATP,CTP, UTP, 2 mM GTP and 8 mM cap analogue

bacteriophage T7 RNA polymerase, ribonuclease inhibitor and other unlisted components

NotI-cutted

RNnase I-free in $50 \%$ glycerol buffer

7.5 M LiCl, $75 \mathrm{mM}$ EDTA

Template cDNA $(5 \mu \mathrm{g})$ was digested with NotI ( $5 \mathrm{U} / \mu \mathrm{g}$ DNA) for 3 hour at $37^{\circ} \mathrm{C}$, then purified using the PCR-purification kit from QIAGEN. For cRNA synthesis, the reaction mixture consisted of $2 \mu \mathrm{l} 10 \mathrm{x}$ transcription buffer, $10 \mu \mathrm{l} 2 \mathrm{x}$ ribonucleotide mix, approximately $1 \mu \mathrm{g}$ NotI-cut template DNA, $2 \mu \mathrm{l}$ enzyme mix and nuclease free water to $20 \mu \mathrm{l}$. The reaction mix was incubated at $37^{\circ} \mathrm{C}$ for 2 hours, then the template DNA was removed by DNase I digestion at $37^{\circ} \mathrm{C}$ for $15 \mathrm{~min}$. The reaction was stopped by adding $30 \mu \mathrm{l}$ nuclease free water and $25 \mu \mathrm{l}$ precipitation solution and the samples were incubated at $-20^{\circ} \mathrm{C}$ for $1-2$ hours. Afterwards the RNA was collected by centrifugation at maximum speed for $15 \mathrm{~min}$ at $4^{\circ} \mathrm{C}$ and washed with $70 \%$ ethanol. The cRNA was resuspended in $10 \mu \mathrm{l}$ nuclease free water and the concentration was determined. The samples were stored at $-80^{\circ} \mathrm{C}$. 


\subsection{BOVINE ADRENOCORTICAL PRIMARY CELL CULTIVATION}

Reagents:

Freshly slaughtered bovine adrenal glands

Phosphate Buffered Salt buffer $\quad 0.144 \mathrm{~g} / \mathrm{L} \mathrm{KH}_{2} \mathrm{PO}_{4}, 9 \mathrm{~g} / \mathrm{L} \mathrm{NaCl}, 0.795 \mathrm{~g} / \mathrm{L}$ $\mathrm{Na}_{2} \mathrm{HPO}_{4}-7 \mathrm{H}_{2} \mathrm{O}, 100 \mathrm{U}$ penicillin/ml, $100 \mu \mathrm{g}$ streptomycin $/ \mathrm{ml}$

Wash media (300 ml)

3.6 g Dulbecco's modified Eagle's media, $3 \mathrm{ml}$ Hepes solution (23.83 g Hepes/100 ml water), $12 \mathrm{ml}$ penicillin $(100 \mathrm{U} / \mathrm{ml})$ treptomycine $(100 \mu \mathrm{g} / \mathrm{ml})$ solution, $0.73 \mathrm{~g} \mathrm{NaHCO}, 285 \mathrm{ml}$ distilled water

Digestion media

Culture media (500 ml)

See wash media plus $2.5 \%$ trypsine

$6 \mathrm{~g}$ Dulbecco's modified Eagle's media, $5 \mathrm{ml}$

Hepes, $10 \mathrm{ml}$ penicillin-streptomycine solution, $1.219 \mathrm{~g} \mathrm{NaHCO}_{3}, 50 \mathrm{ml}$ foetal calf serum (FCS)

Tris-ammonium-chloride buffer

Trypanblue solution $0.2 \%(\mathrm{w} / \mathrm{v})$ in PBS buffer

\subsubsection{Transport from the slaughter house}

The bovine adrenals were transported in ice-cold PBS, which contained $100 \mathrm{U}$ penicillin/ml and $100 \mu \mathrm{g}$ streptomycin/ml.

\subsubsection{Cell preparation}

The adrenals were washed in $70 \%$ ethanol and cut longitudinally into two pieces. The marrow and the capsule were removed and the cortex was cut into very small pieces, which were put immediately into pre-warmed wash media. The pieces were washed three times for 20 minutes on $37^{\circ} \mathrm{C}$ shaker by replacing the wash-media through sterile sieves, and the filtered solutions were discarded. Sterile trypsin $(2,5 \%)$ was put into the digestion-media and the pieces were digested three times-each time not longer than 20 minutes - in digestion media by replacing the medium through sterile sieves. Sterile PBS solution was put into the filtered solution to stop digestion Thereafter it was filtered through sterile Nylon-gauzes. The cell suspension was centrifuged at $1200 \mathrm{rpm}$ for 8 minutes. To remove the erythrocytes $1 \mathrm{ml}$ Tris-ammonium-chlorid buffer added to the sediment. It was incubated for 10 minutes in room temperature, then the cells were 
washed and centrifuged two times with the pre-warmed culture media. The supernatant was removed and the cells were dispersed in pre-warmed culture media.

\subsubsection{Viable cell counts using trypan blue solution}

The reactivity of trypan blue is based on the fact that the chromopore is negatively charged and does not interact with the cell unless the membrane is damaged. Cell suspension $(20 \mu \mathrm{l})$ and 1:10 diluted trypan blue stain $(20 \mu \mathrm{l})$ were mixed and the cells were counted in a hemocytometer (Neubauer chamber).

[Counted cell number / 4] X 2 X $10000 \mathrm{X}$ volume (in ml) = total cell number

The cells were plated into Falcon 6-well plates at a density of approximately $6 \times 10^{5}$ cells/well. The culture media was changed every day.

\subsection{CULTIVATION OF HUMAN ADRENOCORTICAL CARCINOMA CELLS (NCl-H295R)}

Reagents:

Culture media

Dulbecco's Modified Eagle's Media Nutrient Mixture F-12 Ham cointains: $15 \mathrm{mM}$ HEPES, $1 \mathrm{ml} \mathrm{ITS}^{+}$Premix/100 ml media $(0.00625 \mathrm{mg} / \mathrm{ml}$ insulin, $0.00625 \mathrm{mg} / \mathrm{ml}$ transferrin, $6.25 \mathrm{ng} / \mathrm{ml}$ selenium, $1.25 \mathrm{mg} / \mathrm{ml}$ bovine serum albumin, $0.00535 \mathrm{mg} / \mathrm{ml}$ linoleic acid), $1 \mathrm{ml}$ penicillin streptomycinesolution, $1 \mathrm{ml}$ glutaric acid, $2.73 \mathrm{ml} \mathrm{Nu}$ Serum/100 ml media

Trypsine-EDTA solution ( $0.25 \%$ trypsine, $0.03 \%$ EDTA)

DMSO solution

\subsubsection{Cryopreservation}

The cells were cryopreserved to avoid loss by contamination, and to minimise genetic change. The cells were detached from the substrate with dissociation agents (trypsine), and afterwards resuspended in a complete growth medium, and established the viable cell count. The cells were aliquoted in a concentration between $1-5 \times 10^{6}$ cells $/ \mathrm{ml}$ into freeze media (95\% culture media and 5\% DMSO). The cryogenic storage vials placed 
on ice, and within 5 min in an insulated box in a $-80^{\circ} \mathrm{C}$ freezer for overnight. Finally, the vials were stored in liquid nitrogen.

\subsubsection{Thawing of cryopreserved cells}

Cryopreserved cells are fragile and require gentle handling. The cells were quickly thawed in a $37^{\circ} \mathrm{C}$ water bath after being removed from liquid nitrogen. Then the cells were plated directly into complete culture media and centrifuged at $1000 \mathrm{rpm}$ for $5 \mathrm{~min}$ to remove cryopreservative (DMSO). The cells were then resuspended in complete culture media and plated in culture vessel.

\subsubsection{Dissociation of cells from culture vessel}

The following method is a gentle treatment to remove cells from the substratum while maintaining cellular integrity.

First the spent culture media was removed, and the cells were washed using balanced salt solution without calcium and magnesium. The dissociation solution $(0.25 \%$ trypsine, $0.03 \%$ EDTA solution) was added to the side of the flask opposite to the cells $\left(2.5 \mathrm{ml} / 25 \mathrm{~cm}^{2}\right)$. The flask was incubated for about $5 \mathrm{~min}$ at $37^{\circ} \mathrm{C}$, then it was rocked gently and with adding culture media the reaction was stopped. The solution was centrifuged at $1000 \mathrm{rpm}$ for $8 \mathrm{~min}$ and the cells were dispersed in complete media. The cells were counted and subcultured. The media were changed 2 times weekly.

\subsection{RADIOCTIVE TRANSPORT INTO THE CELLS}

Reagents:

PBS buffer

Transport media Dulbecco's Modified Eagles's Medium Nutrient Mixture F12 HAM with L-Glutamine and $15 \mathrm{mM}$ HEPES, without phenol red and sodium bicarbonate

Ringer solution $\quad 5.4 \mathrm{mmol} / \mathrm{L} \mathrm{KCl}, 10 \mathrm{mmol} / \mathrm{L}$ Tris, $2.8 \mathrm{mmol} / \mathrm{L} \mathrm{CaCl}_{2}, 137$

ACTH (Synacten) $10^{-7} \mathrm{M}$ $\mathrm{mmol} / \mathrm{L} \mathrm{NaCl} 1.2 \mathrm{mmol} / \mathrm{L} \mathrm{MgSO}_{4}, \mathrm{pH} 7.4$

Forskolin

Para-aminohippurate solution $(5 \mu \mathrm{M})$

$1 \mathrm{~N} \mathrm{HCl}$ and $1 \mathrm{~N} \mathrm{NaOH}$ 
Confluent cell cultures (which were at least three days old) were taken for radioactive uptake experiments. After washing the cells with pre-warmed PBS buffer, $3 \mathrm{ml}$ prewarmed transport media or Ringer solution with or without substrate was added onto the cells. To stimulate cortisol synthesis $30 \mu \mathrm{l}\left(10^{-7}\right)$ ACTH was added into the medium and incubated for 3 hours in the incubator. The medium was changed as required for the actual experiment and the cells were incubated with the test substrate for the indicated time period. Radioactive PAH $(5.5 \mu \mathrm{M})$ was given into the medium (not directly onto the cells) and which was then mixed well. It was incubated for the indicated incubation time - normally 10 minutes - at $37^{\circ} \mathrm{C}$. After incubation the plates were placed on ice, and $10 \mu \mathrm{l}$ from each well was taken for measuring the radioactivity in the medium. For measurements of ${ }^{3} \mathrm{H}-\mathrm{PAH}$ uptake, the cells were washed three times with ice-cold PBS and then lysed in $1 \mathrm{ml} 1 \mathrm{~N} \mathrm{NaOH}$. After neutralisation with $1 \mathrm{~N}$ $\mathrm{HCl}, 4 \mathrm{ml}$ of scintillation cocktail (Ultima Gold, Packard, Meriden, Conn., USA) was added, and radioactivity taken up by the cells was measured by liquid scintillation counting.

\subsection{RADIOIMMUNOASSAY (RIA)}

The concentrations of cortisol in the culture supernatants were determined by a radioimmunassay. The antiserum employed was raised against corticosterone, but showed $100 \%$ cross-reactivity with cortisol. The cross-reactivity with other steroids like aldosterone, progesterone, androstendion or testosterone was less than $0.1 \%$. The antibody was diluted 1:2000 with PBS buffer containing $0.1 \%$ gelatin. The ${ }^{3} \mathrm{H}$ corticosterone tracer was purchased from NEN (Bad Homburg, Germany), while unlabelled corticosterone used as a standard was supplied by Sigma. The sample volume was either 10 or $25 \mu \mathrm{l}$ culture supernatant. Bound and free tracers were separated by dextran-coated charcoal. The limit of detection of this RIA was $1 \mathrm{ng} / \mathrm{ml}$. Inter- and intra-assay coefficiens of variation, as determined by multiple duplicate determination of a pool of culture supernatants were $15.6 \%$ and $7.5 \%$, respectively.

\subsection{XENOPUS LAEVIS OOCYTES}

To determine the function of oatp3 cloned from the rat adrenal gland, and to demonstrate corticosterone transport mediated by the ROAT1 clone, Xenopus laevis 
oocytes were injected with cRNA derived from the previously mentioned genes and uptake assays were carried out.

\subsubsection{Preparation of oocytes}

Reagents:

Barth's medium

$88 \mathrm{mM} \mathrm{NaCl}, 1 \mathrm{mM} \mathrm{KCl}, 0.3 \mathrm{mM} \mathrm{Ca}\left(\mathrm{NO}_{3}\right)_{2}, 0.41 \mathrm{mM}$ $\mathrm{CaCl}_{2}, 0.82 \mathrm{mM} \mathrm{MgSO} 4,15 \mathrm{mM}$ HEPES, $10 \mathrm{mg} / \mathrm{ml}$ Gentamicin, pH 7.6

Collagenase

Oocytes were separated by collagenase treatment involved overnight incubation of several ovarian lobes in $20 \mathrm{ml}$ Barth's medium containing $5 \mathrm{mg} / \mathrm{ml}$ collagenase. On the following day the oocytes were washed several times with Barth's solution, and after sorting were then incubated for $10 \mathrm{~min}$ in $\mathrm{Ca}^{+}$free medium. Oocytes were stored in Barth's medium at $18^{\circ} \mathrm{C}$.

\subsubsection{Injection of cRNA}

Oocytes were injected with approximately $25 \mathrm{ng}$ of cRNA to be tested in a 23-46 nl volume, or the equivalent volume of nanopure water as a control, using Nanolitre injector.

\subsubsection{Transport assay with Xenopus oocytes}

Reagents:

ORI

$90 \mathrm{mM} \mathrm{NaCl}, 3 \mathrm{mM} \mathrm{KCl}, 2 \mathrm{mM} \mathrm{CaCl} 2,1 \mathrm{mM} \mathrm{MgCl} 2$, 5 mM HEPES, pH 7.6

On the second or third day after injection, surviving oocytes were sorted and transferred into ORI. After equilibration in ORI, oocytes were moved to ORI uptake medium containing the investigated radiolabelled and nonradiolabelled substrates. Uptake took 
place from $10 \mathrm{~min}$ to 1 hour at room temperature. Adding ice-cold ORI medium stopped the uptake, and then the oocytes were washed three times with ice-cold ORI solution. After that individual oocytes were transferred to $5 \mathrm{ml}$ scintillation vials containing $200 \mu \mathrm{l} 1 \mathrm{~N} \mathrm{NaOH}$ to dissolve the oocytes. After incubation overnight, the solution was neutralised by addition of $200 \mu \mathrm{l} \mathrm{N} \mathrm{HCl}$, and finally $2 \mathrm{ml}$ scintillation fluid was added. The mixture was vortexed thoroughly and the radioactivity taken by the oocytes was measured in a scintillation counter. 


\section{$4 \quad$ RESULTS}

\section{1 ${ }^{3} \mathrm{H}-\mathrm{PAH}$ UPTAKE INTO BOVINE ADRENOCORTICAL PRIMARY} CELLS

Glucocorticoids synthesized in the adrenocortical cells are released into the blood in response to ACTH. It has long been assumed that this occurs via exocytosis or simple diffusion, although the exact mechanism is still unknown. Recently, the existence of a probenecid-inhibitable exchange transporter system involved in cortisol release has been demonstrated in primary bovine adrenocortical cells (Steffgen et al. 1996). This transporter showed properties similar to the renal $p$-aminohippurate/dicarboxylate exchanger. To further characterize the attributes of the putative transporter, the uptake of radioactive $p$-aminohippurate $\left({ }^{3} \mathrm{H}-\mathrm{PAH}\right)$ into bovine adrenocortical primary cell cultures under different conditions was measured. In parallel, the release of cortisol from adrenocortical cells was also tested (Steffgen et al. 1999).

Trans-stimulation means in an exchange transport system that the cells were incubated for the indicated time with a (possible) substrate of the investigated transporter. Cells should accumulate this substance, then the uptake of the radioactive material should be increased.

Cis-inhibition means that non-radioactive (possible) substrate was added at a high concentration besides the radioactive substance to the transport media. If the nonradioactive substance is also transported, the uptake of radioactivity should be decreased due to competition for the same transporter.

\subsubsection{ACTH stimulation of bovine adrenocortical cells}

Under physiological conditions ACTH increases the production of cortisol. The confluent monolayer cell culture was incubated with $1 \mathrm{nM}$ ACTH to stimulate cortisol release from the cells. This treatment also stimulated ${ }^{3} \mathrm{H}-\mathrm{PAH}$ uptake into the 
adrenocortical cells (mean stimulation in 9 independent experiments was 1.98 fold, $\mathrm{p}<$ 0.05 , figure 4.).

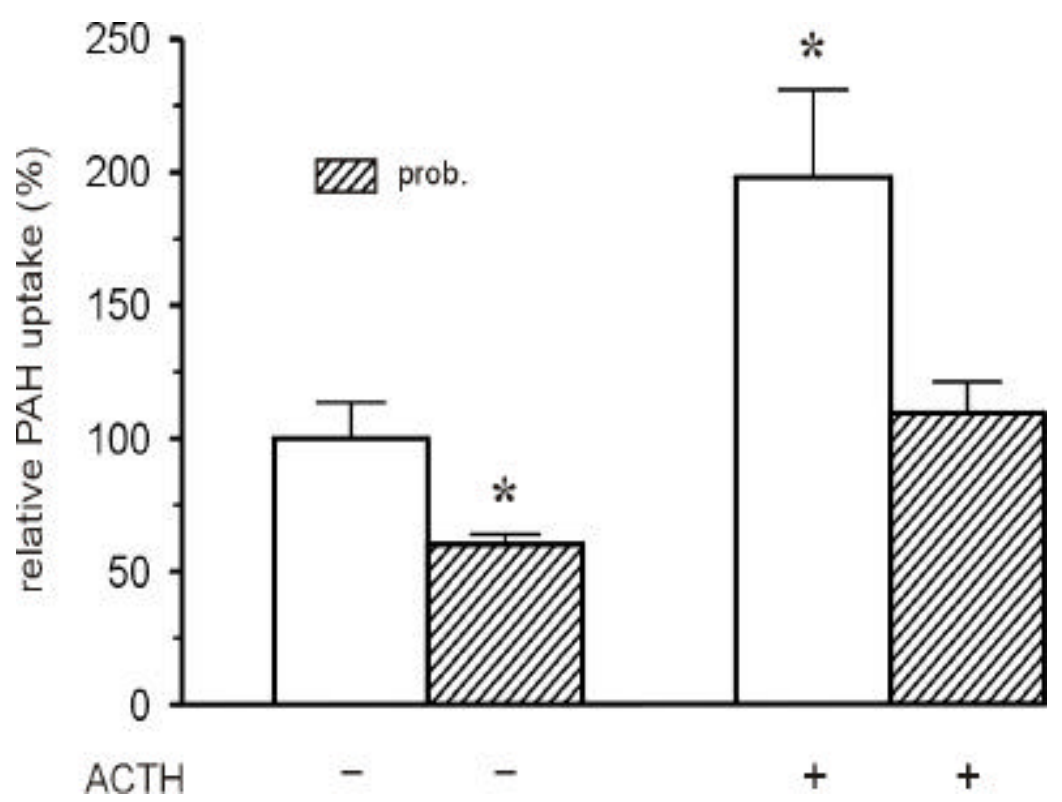

Figure 4. Stimulation by ACTH and inhibition by probenecid of uptake of ${ }^{3} \mathrm{H}-\mathrm{PAH}$ into bovine adrenocortical cells. Cells were incubated with $5.5 \mu \mathrm{M}{ }^{3} \mathrm{H}-\mathrm{PAH}$ for $10 \mathrm{~min}$ in the absence (open column) and in the presence (hatched column) of probenecid. The PAH uptake in the absence of ACTH and probenecid was set $100 \%$. Data represent means \pm SEM of six independent experiments with 3-6 wells per condition. * $\mathrm{p}<0.05$

The stimulation of cortisol release and radioactive PAH uptake could be explained by an exchange transporter shared by both substrates. It follows that the increased synthesis and release of cortisol by ACTH trans-stimulated PAH uptake into the cells.

\subsubsection{Inhibition of ${ }^{3} \mathrm{H}-\mathrm{PAH}$ uptake into bovine adrenocortical cells by probenecid}

In the presence of $5 \mathrm{mM}$ probenecid (the classical inhibitor of the renal organic anion transporter), cortisol release from the cells and radioactive PAH uptake into the cells were decreased. Mean inhibition of probenecid of ACTH-stimulated radioactive PAH uptake was $45.7 \pm 5.9 \%$ in 10 independent experiments (Figure 4.). There was no significant difference in the relative inhibitory effect of probenecid on radioactive PAH 
uptake between ACTH treated cells $(45.7 \pm 5.9 \%$ inhibition) and non-treated cells (40.8 $\pm 3.7 \%$ inhibition).

The culture media of the cells contained phenol red as $\mathrm{pH}$ indicator, which is known to interact with the presumed transporter (Shannon et al. 1938). To exclude this interaction probenecid inhibition on radioactive PAH transport was tested in phosphatebuffered saline (PBS) and Ringer's solution. There was no significant statistical difference between these three incubation solutions on probenecid inhibition of radioactive $\mathrm{PAH}$ uptake into the cells (Table 1.).

\begin{tabular}{ccc}
\hline Incubation solution & $\begin{array}{l}\text { Relative inhibition } \\
\text { of radioactive PAH } \\
\text { uptake by probenecid, \% }\end{array}$ & Experiments/wells \\
\hline Culture media & $45.7 \pm 5.9$ & $10 / 48$ \\
\hline PBS & $39.9 \pm 5.1$ & $12 / 59$ \\
\hline Ringer's solution & $35.8 \pm 3.3$ & $4 / 15$ \\
\hline
\end{tabular}

Table 1. Relative inhibition of radioactive PAH uptake by probenecid in different incubation solutions. Data are mean \pm SEM of the indicated number of experiments. Statistical analysis was done by Student's t test in comparison to culture media.

\subsubsection{Trans-stimulation of ${ }^{3} \mathrm{H}$-PAH uptake into bovine adrenocortical cells with $1 \mathrm{mM}$ non-radioactive PAH}

After preincubation of the cells for 1 hour with $1 \mathrm{mM}$ non-radioactive PAH the cortisol release decreased about 33\%. This might be interpreted as competition of the intracellularly accumulated non-radioactive PAH with the cortisol for the common transporter. On the other hand radioactive PAH uptake into the cells was increased by about $30 \%$ after 1 hour preincubation with $1 \mathrm{mM}$ nonradioactive PAH (Figure 5.). This increase was probably due to more exchange substrate on the trans side of the shared transporter. 


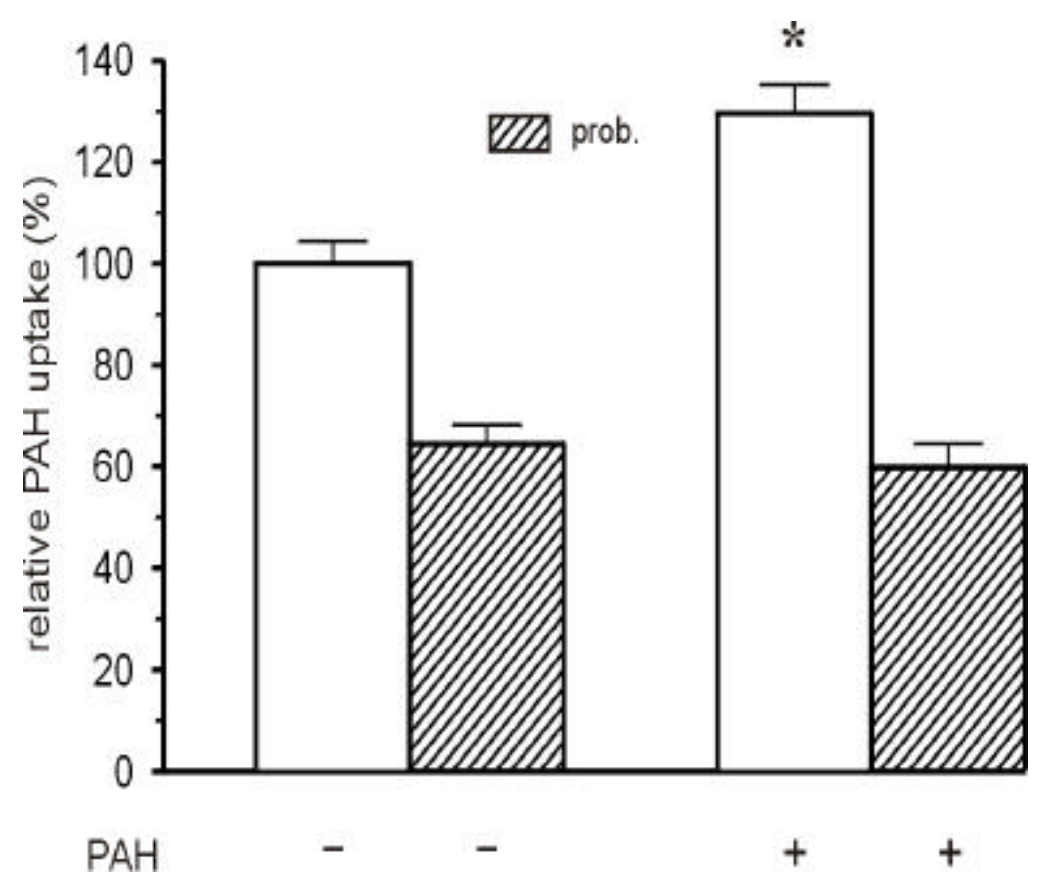

Figure 5. Influence of preincubation with $1 \mathrm{mM}$ PAH on ${ }^{3} \mathrm{H}-\mathrm{PAH}$ uptake into bovine adrenocortical cells. Cells were preincubated with cell culture medium (-) or with medium supplemented with $1 \mathrm{mM}$ $\mathrm{PAH}(+)$ for 1 hour, washed, and incubated $10 \mathrm{~min}$ with $5.5 \mu \mathrm{M}{ }^{3} \mathrm{H}-\mathrm{PAH}$ in the absence (open column) or presence (hatched column) of probenecid. Radioactive PAH uptake in the absence of probenecid and without preincubation was set to $100 \%$. Data represent means \pm SEM of five independent experiments with 3-6 wells per condition. * $\mathrm{p}<0.05$

\subsubsection{Cis-inhibition of ${ }^{3} \mathrm{H}-\mathrm{PAH}$ uptake into bovine adrenocortical cells with non-radioactive PAH}

As preincubation with $1 \mathrm{mM}$ PAH increased radioactive PAH uptake into the cells, the effect of high concentrations of non-radioactive PAH in the incubation media was also tested. The expected outcome was cis-inhibition of radioactive PAH uptake as a result of competition. In comparison to inhibition by $5 \mathrm{mM}$ probenecid, the mean inhibition of $1 \mathrm{mM}$ nonradioactive PAH on radioactive PAH uptake into the cells was $40 \pm 9.9 \%$ in 4 independent experiments, $\mathrm{p}<0.01$ (Figure 5.). Increasing concentrations of nonradioactive $\mathrm{PAH}$ in the incubation media caused concentration-dependent inhibition of radioactive PAH uptake (Figure 6 A.). The inhibitory effect saturated around 1-5 mM non-radioactive PAH. 
A

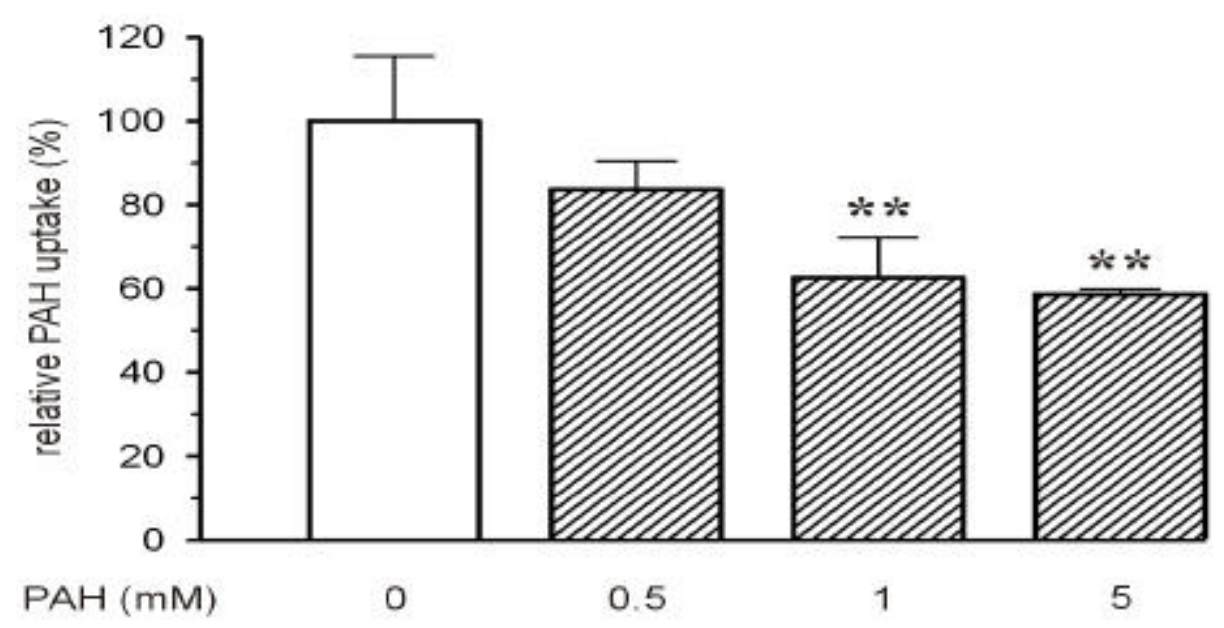

B

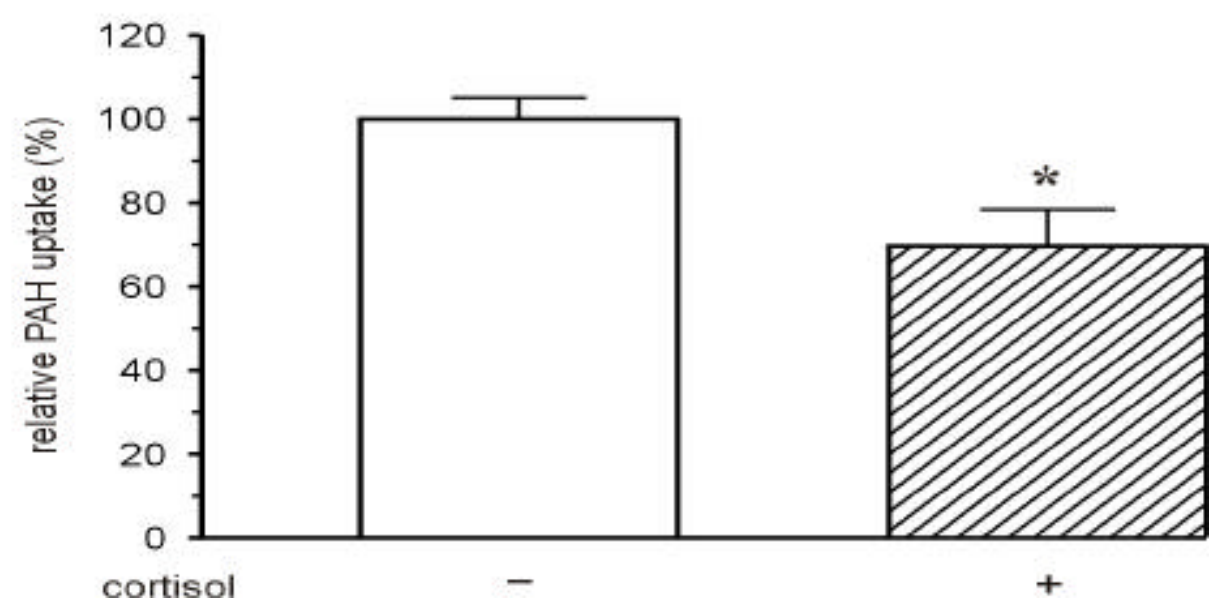

Figure 6. Influence of PAH and cortisol in the incubation medium on ${ }^{3} \mathrm{H}-\mathrm{PAH}$ uptake into adrenocortical cells. A., Cells were incubated with $5.5 \mu \mathrm{M} 3 \mathrm{H}-\mathrm{PAH}$ in the absence or presence of different concentrations of non-radioactive PAH. B., Cells were incubated for $10 \mathrm{~min}$ with $5.5 \mu \mathrm{M}{ }^{3} \mathrm{H}$ PAH in the presence of $1 \mathrm{mM}$ cortisol. The uptake of radioactive PAH in the absence of unlabelled PAH was set at $100 \%$. Data represent means \pm SEM of five independent experiments with 3-6 wells per condition.

\subsubsection{Cis-inhibition of ${ }^{3} \mathrm{H}$-PAH uptake into bovine adrenocortical cells with $1 \mathrm{mM}$ cortisol}

In a model of an exchange transporter, a high concentration of cortisol on the outside should cis-inhibit radioactive PAH uptake, since preincubation with PAH inhibited cortisol release from the cells. In the presence of $1 \mathrm{mM}$ cortisol in the transport medium 
$31 \pm 8.8 \%$ inhibition was detected (Figure 6 B.), compared to $45.7 \pm 5.9 \%$ by probenecid. This inhibitory effect was indicative of competition between cortisol and PAH for the same transporter.

\subsubsection{Cis-inhibition of ${ }^{3} \mathrm{H}-\mathrm{PAH}$ into bovine adrenocortical cells with $1 \mathrm{mM}$ glutarate}

As glutarate - a model substrate of the renal organic anion transporter that is not metabolized - stimulated cortisol release from the cells about 2 fold, the effect of glutarate on radioactive PAH uptake was tested. Mean inhibition of radioactive PAH uptake by glutarate into the cells was $53 \%(\mathrm{p}<0.01)$ in 4 independent experiments (Figure 7.). A higher concentration of glutarate $(10 \mathrm{mM})$ in the incubation medium did not increase the inhibitory effect on radioactive PAH uptake.

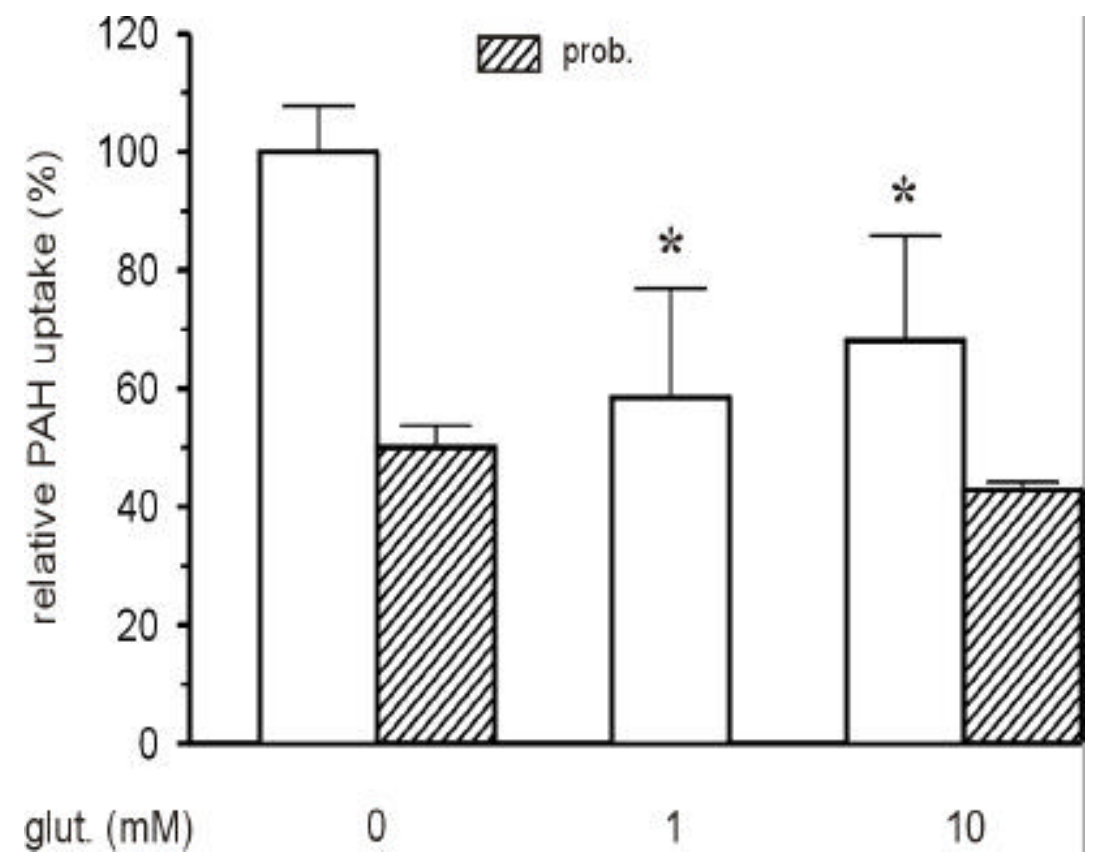

Figure 7. Influence of glutarate in the incubation medium on ${ }^{3} \mathrm{H}-\mathrm{PAH}$ uptake into bovine adrenocortical cells. Cells were incubated with or without 1 or $10 \mathrm{mM}$ glutarate (glut.) in the absence (open column) or presence (hatched column) of $5 \mathrm{mM}$ probenecid for $10 \mathrm{~min}$. Uptake of radioactive PAH in the absence of glutarate and probenecid was set at $100 \%$. Data represent means \pm SEM of five independent experiments with 3-6 wells per condition. 


\subsection{CIS-INHIBITION OF ROAT1-MEDIATED PAH UPTAKE BY CORTICOSTERONE}

Cis-inhibition studie was carried out with corticosterone, the main glucocorticoid in rats, in order to determine if corticosterone is a possible substrate of the rat renal organic anion transporter (Fig. 8.). Corticosterone strongly inhibited PAH uptake in ROAT1injected oocytes by more than 70\% (the expression clone of ROAT1 was a gift of Dr.Andrew Bahn, Department of Vegetative Physiology and Pathophysiology, GeorgAugust Göttingen, Germany).

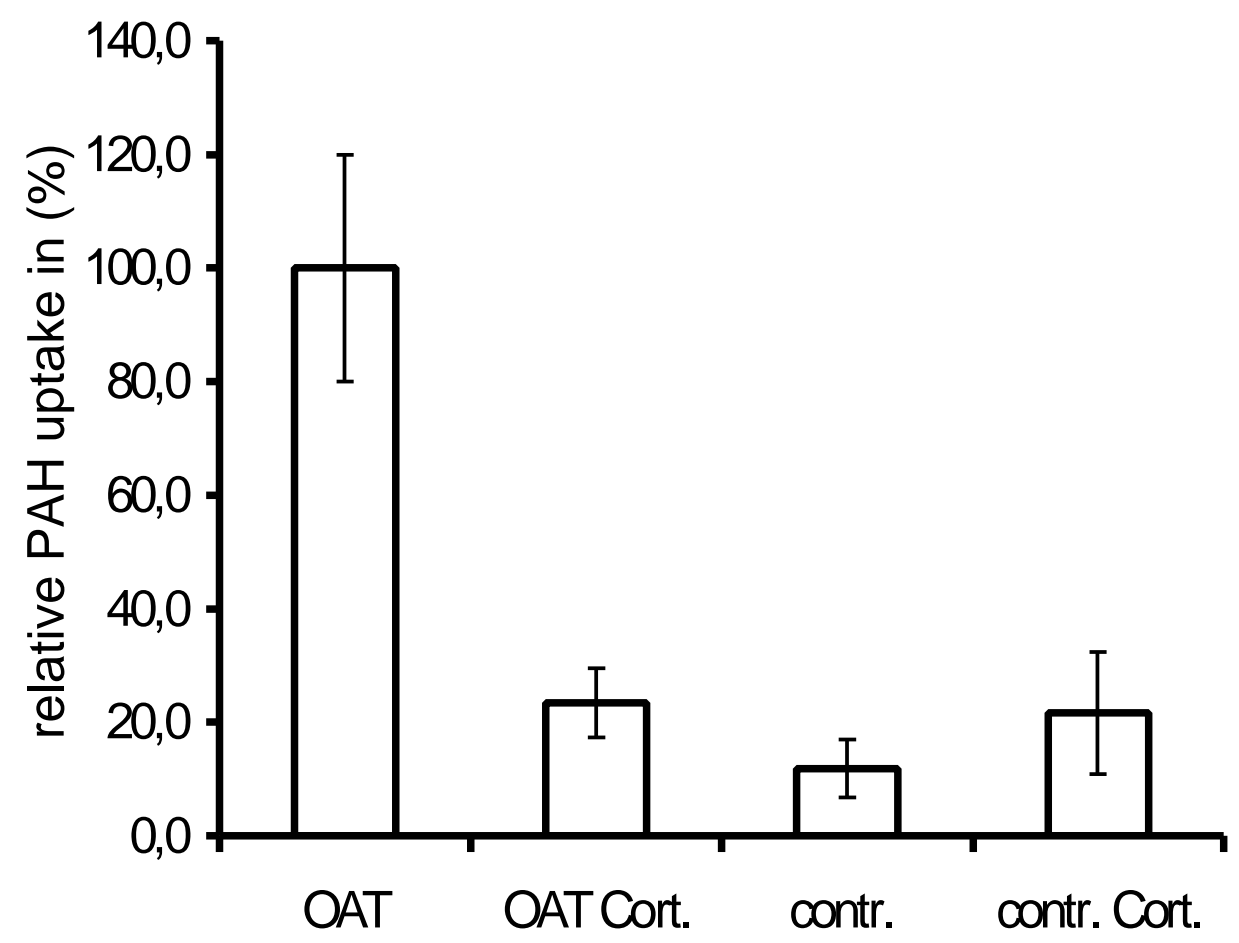

Figure 8. Cis-inhibition of ROAT1-mediated PAH uptake by corticosterone. The effect of corticosterone (Cort.) on control level of ROAT1-mediated PAH uptake is shown. Corticosterone was present in the uptake medium at a concentration of $500 \mu \mathrm{M}$. Uptake of radioactive PAH in the absence of corticosterone was set at $100 \%$. Data represent means \pm SEM of 3 independent experiments with 7-12 oocytes per group. 


\subsection{DEMONSTRATION OF A Na+-DICARBOXYLATE COTRANSPORTER IN BOVINE ADRENOCORTICAL CELLS}

\subsubsection{Characterization of ${ }^{14} \mathrm{C}$-succinate uptake into bovine adrenocortical cells}

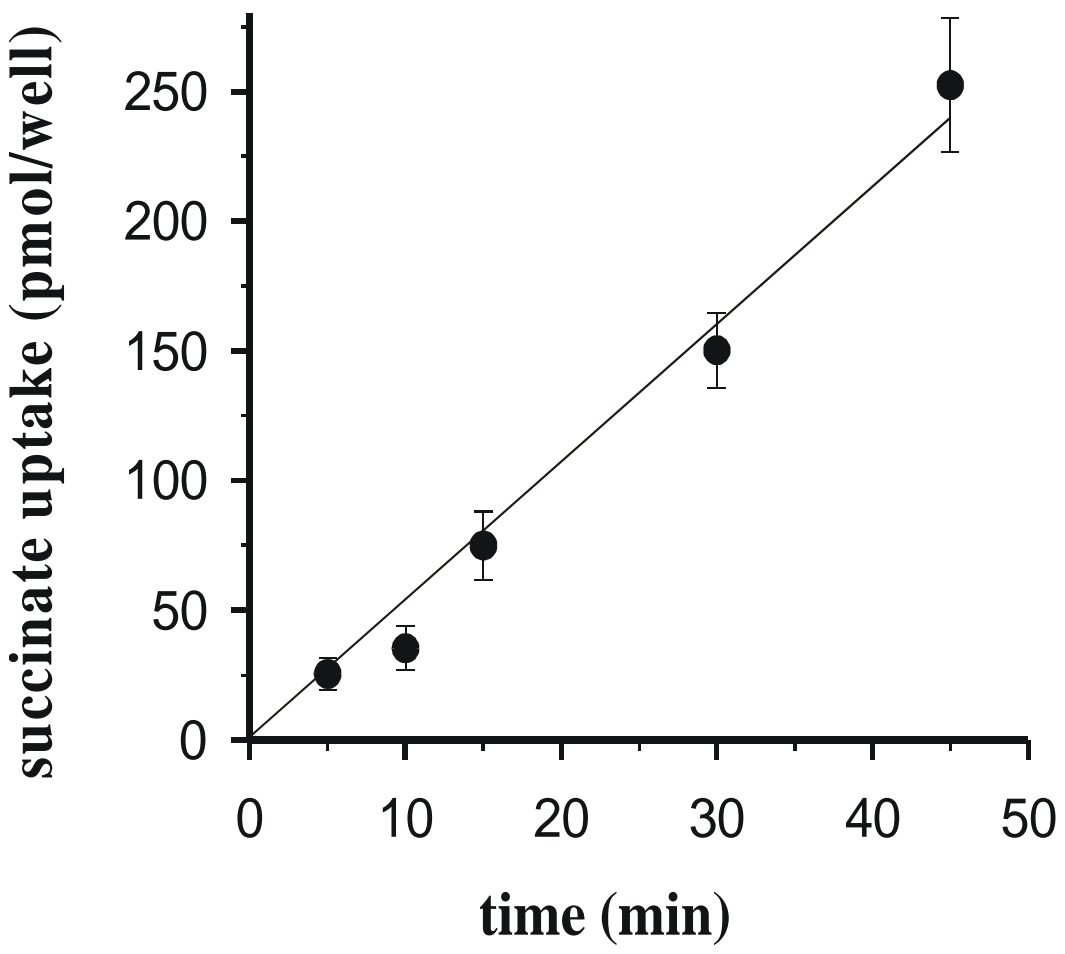

Figure 9. Time-dependency of ${ }^{14} \mathrm{C}$-succinate $(58 \mu \mathrm{mol} / \mathrm{l})$ uptake into bovine adrenocortical cells. Data represent means \pm SEM of five independent experiments with 3-6 wells per condition.

As shown in Figure 9., uptake of ${ }^{14} \mathrm{C}$-succinate, the model substrate of the $\mathrm{Na}^{+}$dicarboxylate cotransporter, into bovine adrenocortical cells increased linearly with time for at least $45 \mathrm{~min}(\mathrm{r}=0.99)$. As calculated from the slope, the uptake rate amounted to 0.557 pmol succinate per min per well. For all further experiments, an incubation period of $30 \mathrm{~min}$ was chosen. Inhibition of dicarboxylate uptake by lithium has been reported for $\mathrm{Na}^{+}$-dicarboxylate cotransporters in all mammalian tissues studied so far. Succinate uptake into bovine adrenocortical cells could be inhibited by $10 \mathrm{mM}$ lithium by $75 \% \pm 6.8 \%$ in three independent experiments (Fig. 10 A.). 

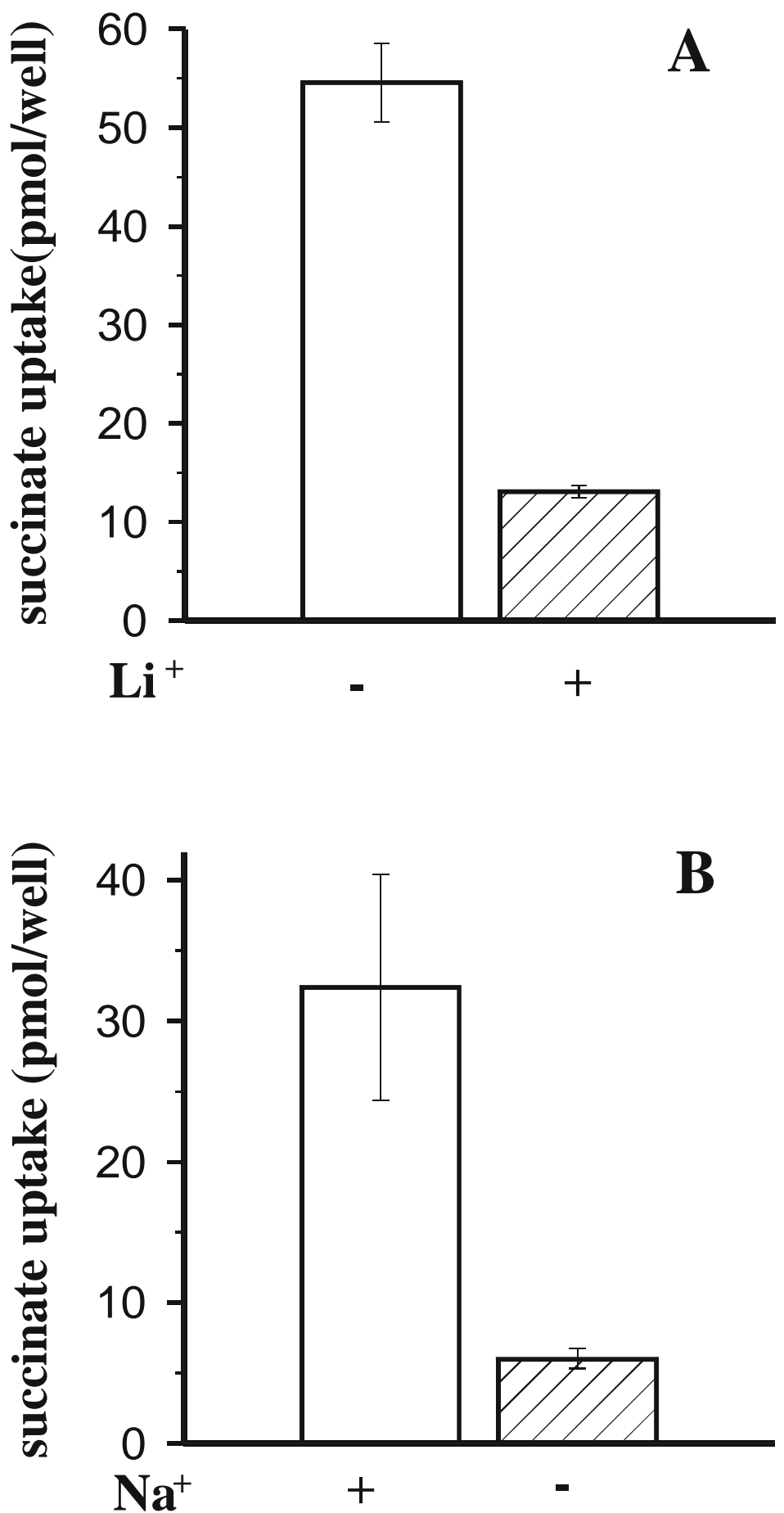

Figure 10. Inhibition of succinate uptake $(30 \mathrm{~min})$ by $10 \mathrm{mmol} / \mathrm{l}$ lithium in the presence of sodium in culture medium (A) and dependence of succinate uptake on sodium in Ringer's solution (B). To test sodium dependency, $\mathrm{Na}^{+}$was replaced by tetramethylammonium. Succinate concentration was $58 \mu \mathrm{mol} / 1$ in each experiment. Data represent means \pm SEM of five independent experiments with 3-6 wells per condition

To test sodium-dependence of succinate uptake, experiments were performed in a Ringer's solution in the presence and absence of sodium (Fig. 10 B). Succinate uptake 
into bovine adrenocortical cells incubated in the presence of sodium was about 7 times higher than in the absence of sodium, obviously proving sodium-dependence.

The succinate uptake was saturable with calculated apparent $\mathrm{K}_{\mathrm{m}}$ value of $146.2 \pm 5.1 \mu \mathrm{M}$ succinate (data taken from Steffgen et al. 1999).

\begin{tabular}{|c|c|}
\hline Substrate & Relative uptake (\%) \\
\hline None & 100 \\
\hline Cis-aconitate & $100 \pm 12$ \\
\hline Citrate & $93 \pm 12$ \\
\hline Fumarate & $30 \pm 5$ \\
\hline Glutarate & $26 \pm 4$ \\
\hline Isocitrate & $112 \pm 13$ \\
\hline$\alpha-$ Ketoglutarate & $32 \pm 4$ \\
\hline Malate & $125 \pm 13$ \\
\hline Maleate & $77 \pm 15$ \\
\hline Malonate & $80 \pm 14$ \\
\hline Succinate & $14 \pm 2$ \\
\hline
\end{tabular}

Table 2. Effect of $1 \mathrm{mmol} / \mathrm{l}$ of various potential substrates on ${ }^{14} \mathrm{C}$-succinate $(58 \mu \mathrm{mol} / \mathrm{l})$ uptake into bovine adrenocortical cells. Uptake in the absence of nonradioactive substrate was set to 100\%. Data represent means \pm SEM from three to five independent experiments with three to six wells.

The specificity of the succinate transporter was also tested with several di- and tricarboxylates (Table 2.). Inhibition induced by $1 \mathrm{mM}$ of potentional substrates ranked in the following order: succinate $>$ glutarate $>$ fumarate $=\alpha$-ketoglutarate $>$ maleate. There was only a slight inhibition by malonate and no inhibition by citrate, malate and isocitrate. The lack of inhibition by citrate on succinate uptake at $\mathrm{pH} 7.4$ is different from the data reported for the sodium-dicarboxylate transporters in all other investigated organs. 


\subsection{PCR CLONING OF ORGANIC ANION TRANSPORTERS FROM THE ADRENAL GLAND}

To support the hypothesis of the existence of organic anion transporter system(s) in the adrenal gland, a homology cloning PCR technique was employed, using the sequence data of the cloned flounder, rat and human transporters. As template, bovine and rat adrenal cDNA was used, prepared as described in 3.3.



Picture 2. Bovine and rat adrenal total RNA separated in a $1.2 \%$ formamid-formaldehyd gel. Total RNA was isolated from rat and bovine adrenal glands with Qiagen Total RNA Maxi Kit. A: rat mRNA, B: bovine mRNA

PCR parameters (annealing temperature, template and $\mathrm{MgCl}_{2}$ concentrations and adjuvants) for each sample were experimentally determined. The primers were based on conserved parts of the nucleic acid sequence of the cloned organic anion transporters. 


\begin{tabular}{|c|c|}
\hline Transporter clone & Appearance in GenBank \\
\hline ROAT1 & AF110022, AF008221 \\
\hline fROAT & Z97028 \\
\hline oatp1 & U95031 \\
\hline oatp2 & AF041105 \\
\hline oatp3 & NM012697 \\
\hline OCT1 & D83044 \\
\hline OCT2
\end{tabular}

Table 4. The GenBank EMBL accession numbers of transporter sequences used in this study.

\subsubsection{Cloning of an OAT-like organic anion transporter}

It was suggested from the uptake (this study) and the radioimmuno assay (Steffgen et al. 1999) that an anion exchanger is present in the bovine adrenocortical cells. This transporter was at least partly involved in cortisol release and showed properties similar to the renal para-aminohippurate/dicarboxylate exchanger. To clone this transporter from the adrenals a homology cloning PCR strategy was employed. Initially, bovine adrenal cDNA was used as a template for PCR using degenerate primers based on the sequence of the cloned rat, mouse and flounder organic anion transporters, a related transporter isolated from rat liver (NLT) and two rat organic cation transporters (OCT1 and OCT2) and obtained from Dr. Natasha A. Wolff, Department of Vegetative Physiology and Pathophysiologie, Georg-August University Göttingen, Germany .

\begin{tabular}{|c|c|c|c|}
\hline Primer & Nucleotide sequence & Primers in pool & Degeneracy factor \\
\hline 5.1 & 5'TIATGGCNWSNCAYAAY $^{3}$ & 256 & 1024 \\
\hline 5.2 & 5'GGIACITGYGCNGCNTWY $^{3}$ & 128 & 2048 \\
\hline 5.3 & 5'ARNCCRTARTANGCRAA $^{3}$ & 256 & 256 \\
\hline 5.4 & 5'NCCRAADATNACYTGDAT $^{3}$ & 576 & 576 \\
\hline
\end{tabular}

Table 5. Degenerate primers used in homology screening PCR with bovine adrenal cDNA. Detailed description of the primers found in Reid et al. 1999. $\mathrm{I}=$ inosine, $\mathrm{N}=\mathrm{A} / \mathrm{C} / \mathrm{G} / \mathrm{T}, \mathrm{W}=\mathrm{A} / \mathrm{T}, \mathrm{S}=\mathrm{C} / \mathrm{G}, \mathrm{Y}=$ $\mathrm{C} / \mathrm{T}, \mathrm{R}=\mathrm{A} / \mathrm{G}, \mathrm{D}=\mathrm{A} / \mathrm{G} / \mathrm{T}$. The number of primers in each pool equals the total number of different primers; the degeneracy factor represents the total number of sequences with which each primer might theoretically bind. 
Taking the species differences into consideration, the PCR parameters were chosen to render amplification possible even if the primers had no complete matching to the template. First of all, the annealing temperature was optimized, testing a range of temperatures setting out from the calculated melting temperature (about $40^{\circ} \mathrm{C}$ ). As an alternative, a touchdown protocol was performed, where the annealing temperature was initially set high $\left(50^{\circ} \mathrm{C}\right)$, but decreased by $0.4^{\circ} \mathrm{C}$ with each subsequent annealing step for 25 cycles. The amplified products were sequenced but they proved to be artifacts, mostly house-keeping genes. Moreover, in order to increase effectiveness, several concentrations of $\mathrm{MgCl}_{2}(2.5-5 \mathrm{mM})$, primers $(10-30 \mathrm{pmol})$ and template $(0.1-1 \mu \mathrm{g})$ and adjuvants $(0.01 \%$ gelatine, $4 \%$ DMSO) were also tried. Despite this fact, it proved to be unsuccessful. Afterwards rat adrenal cDNA was used as a template in PCR with less degenerate primers to minimize the problems associated with species-dependent sequence differences.

Rat adrenal cDNA was screened with degenerate primers based on similar nucleic acid sequence parts of rat (r), flounder (f) and human (h) clones (Table 6.). The fr-OAT forward and reverse primer were expected to yield PCR products of 241 bases, respectively. The PCR reaction was optimized for annealing temperature $\left(55^{\circ} \mathrm{C}\right)$ and time (30 sec), $\mathrm{MgCl}_{2}(3 \mathrm{mM})$, primer $(20 \mathrm{pmol})$ and template $(0.2 \mu \mathrm{g}$ rat adrenal cDNA) concentrations and 4\% DMSO was used to increase effectiveness. A product of the predicted size was sequenced and sequence homology searches revealed the product to have $98 \%$ homology to the cloned rat renal OAT1. That was the first molecular evidence for the presence of the renal organic anion transporter in the adrenal gland. This finding is consistent with the previous bovine transport results, as an organic transport-like system exists in the adrenal gland. Later, a 1700 base-pair product, amplified with OAT1U and rhOAT1R primers and rat adrenal cDNA as the template, proved to be the rat renal organic anion transporter, which confirmed the presence of this transporter in the adrenal gland. 


\begin{tabular}{|l|l|}
\hline Primer & Nucleotide sequence \\
\hline frOAT1F & ${ }^{5}$ CCACYAGCTTYGCTTYGCCTACTA \\
\hline frOAT1R & ${ }^{5}$ 'TTCGCACCTSYCTGGCTGT ${ }^{3}$ \\
\hline OAT1F & ${ }^{5}$ GATGTCGACCTATGGCCTTCAACG ${ }^{3 \prime}$ \\
\hline rhOAT1R & ${ }^{5}$ CAGGCCTCARCACAAGAGAAG ${ }^{3}$ \\
\hline
\end{tabular}

Table 6. Primers used to amplify ROAT1 from adrenal cDNA. The small letters of the primer names refer to the clones taken as a basis; $f$ means flounder, $r$ means rat, $h$ means human. $S=C / G, Y=C / T, R=$ $\mathrm{A} / \mathrm{G}, \mathrm{F}=$ forward, $\mathrm{R}=$ reverse

\subsubsection{Cloning of organic anion transporting polypeptide transporters (oatp)-like transporters}

As described in the literature, the organic anion transporting polypeptide family (oatp) interacts with different kinds of steroid hormones (see 1.3.3). Thus, their existence in the rat adrenal cDNA was examined. The three known members of the family share about $86 \%$ identity to each other. The primers were designed as to recognize and to be complementary to all members of the oatp family to screen whether they are expressed in the adrenal gland (Table 7.).

\begin{tabular}{|c|c|}
\hline Primer & Nucleotide sequence \\
\hline oatp5F & 5'GGCAACTTGTCCTCAAAC ${ }^{3 \prime}$ \\
\hline oatp6F & 5'GTGAATACAGATGACCTGACC ${ }^{3}$ \\
\hline oatp8R & 5'GCATGTAAATCGGATTGC $^{3{ }^{\prime}}$ \\
\hline oatp1F & ${ }^{5} \mathrm{CCATGGAAGAAACAGAGAAAAAG}^{3^{\prime}}$ \\
\hline oatp2F & $5^{\prime}$ GAACACCATGGAAGAAAACAGAG ${ }^{3{ }^{\prime}}$ \\
\hline oatp3F & ${ }^{5}$ ATGGGAGAAACAGAGAAAAGGGTTGC ${ }^{3}$ \\
\hline oatp1-2-3R & 5'TTACAGCCTCGTTTTCAGTTCTCCG ${ }^{3 '}$ \\
\hline
\end{tabular}

Table 7. Primers used to amplify the three members (oatp1, oatp2 and oatp3) of the organic anion polypeptide transporter family. The numbers 1 and 2 and 3 refer to the name of the respective transporter, number 5, 6 and 8 are serial numbers of the given primer. $\mathrm{F}=$ forward, $\mathrm{R}=$ reverse

The oatp -6 forward and oatp -8 reverse primers and the oatp -5 forward and oatp -8 reverse primers were expected to yield PCR products of 320 and 590 bases, respectively. As positive control rat liver cDNA was used. The PCR reaction was optimized for annealing temperature $\left(55^{\circ} \mathrm{C}\right)$ and time (15 sec), $\mathrm{MgCl}_{2}(3.5 \mathrm{mM})$, primer (20 pmol) and template $(0.2 \mu \mathrm{g}$ rat adrenal cDNA) concentrations and 4\% DMSO was used to increase effectiveness. After successful amplification, the products of the 
predicted size were sequenced. The sequence data were used to search for homologous clones in Blast searches. The 322 base pairs product was found to be oatp3 (98\% identity) and the 590 base pairs product proved to be oatp2 (96\% identity). The PCRscreen of rat adrenal cDNA indicated the presence of more members of the oatp family. To verify the first PCR results and demonstrate that more organic anion transporting polypeptide transporters are truly expressed in the rat adrenal gland, specific primers were designed for each member of the oatp family (Table 7.). The primers specifically fit to the ends of the open reading frame of the respective transporter and the PCR parameters were optimized to provide high stringency conditions (annealing temperature: $60^{\circ} \mathrm{C}$ ). The whole open reading frame of oatp2 and oatp3 was successfully amplified with proof-reading polymerase (3.4.2), but the amplification of oatp1 ran into difficultes. The amount of the amplified end-product in the case of oatp1 was very low, therefore purification and reamplification of the first PCR product were required. On the basis of the sequence data of the PCR products it was shown that the oatp family with three members is also represented in the rat adrenal gland.

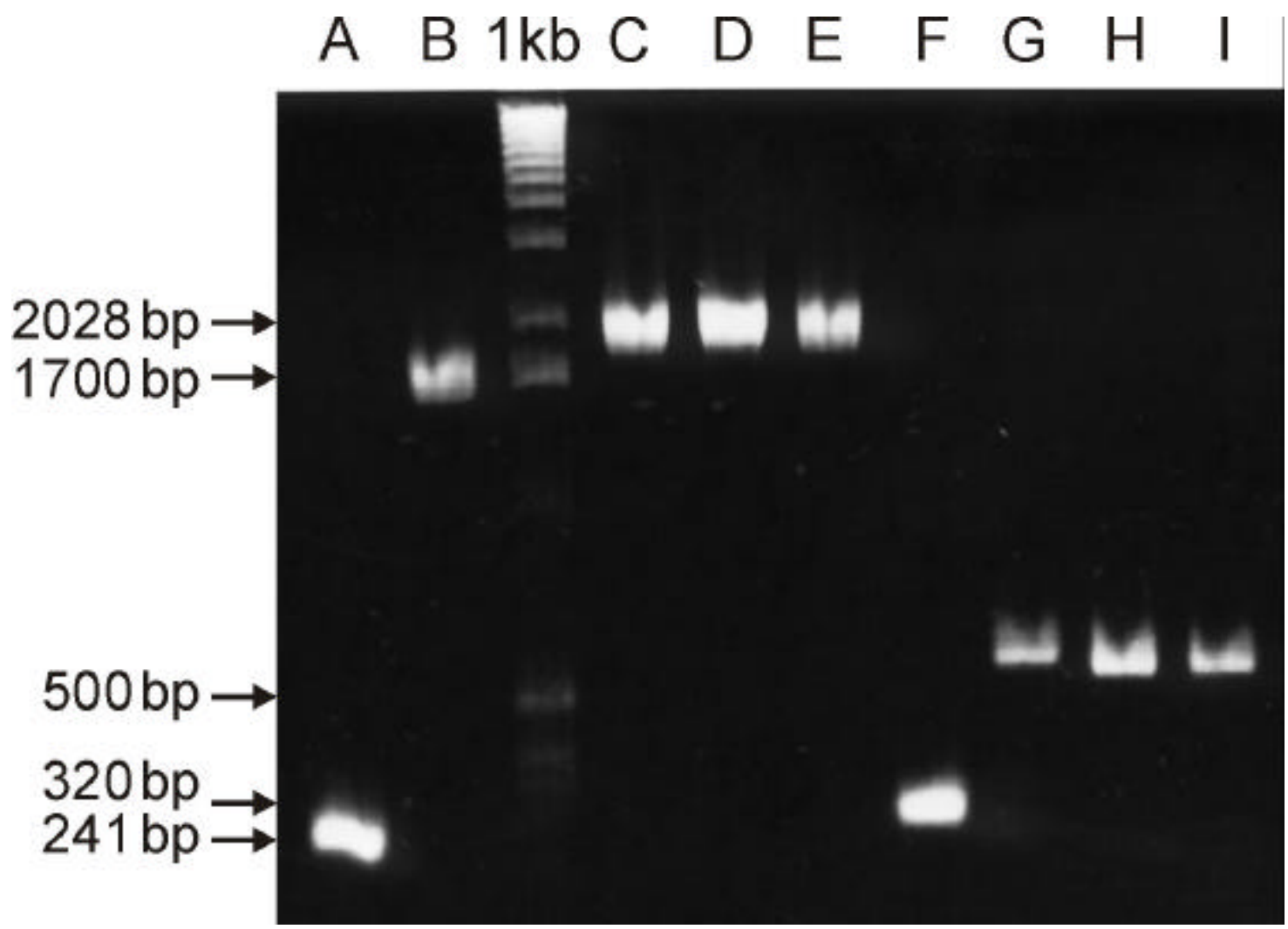

Picture 3. Amplification of OAT1 and oatp1, oatp2 and oatp3 from rat adrenal cDNA by degenerate PCR. A: ROAT1 amplified with frOAT1F-R primers, also template for in situ hybridization, B: ROAT1 amplified with OAT1F-rhOAT1R, C-E: oatp3, oatp2 and oatp1 open reading frames, F: oatp3 amplified with oatp6F-oatp8R, G: oatp2 DNA template for in situ hybridization, H: oatp1 DNA template for in situ hybridization, I: oatp2 amplified with oatp5F-oatp8R primers, Sizes of relevant bands from the $1 \mathrm{~kb}$ standard are shown. 


\subsection{NON-RADIOACTIVE IN SITU HYBRIDIZATION}

PCR revealed that the organic anion transporter (ROAT1) and three members of the organic anion polypeptide family (oatp1, oatp2, and oatp3) are expressed in the rat adrenal gland. As the adrenal gland physiologically is divided into two major parts (cortex and medulla), and the cortex itself has three histologically and functionally separated zones, it was important to identify the localization of the transporters to show relation to the assumed substrates, i.e. steroids. The in situ hybridization method is able to visualize the expression of various genes within the intact cell, in their original context. Part of the respective sequence is used as a template for in vitro digoxigeninlabelled RNA amplification for non-radioactive in situ hybridization. This riboprobe, which hybridizes to its complementary sequence under suitable conditions, is applied to the prepared tissue sections. The hybrid molecules are visualised as an insoluble precipitate with the microscope.

The sequence parts used as DNA templates for in situ hybridization were chosen so as to have low identity to the related transporters. In the case of ROAT1, the sequence part amplified with frOAT1 forward and reverse primers was chosen, while it had low identity to the related organic anion and no identity to the organic cation transporters. In the case of organic anion polypeptide family, care had to be devoted to select the proper part of each transporter, as the members share high identity with each other (about 86\%) in their open reading frame. Since the 3' untranslated regions of oatp1 and oatp2 show higher divergence (about $60 \%$ identity), the probes were amplified from these regions. As the 3' untranslated region of oatp3 was not known, only the open reading frame was available for choosing a suitable part for in situ hybridization. As the fragment amplified with oatp6 forward and oatp8 reverse primers was used as probe for oatp3, to obtain specific results high stringency conditions and controls were used performing the in situ hybridization. Since the probes and the paraffin-embedded adrenal sections were self-made, furthermore the protocol was not applied to adrenal gland, therefore the method had to be optimised in every respect. 


\subsubsection{The empirical arts of in situ hybridization}

It is important to optimize empirically the various experimental parameters of in situ hybridization such as proteinase $\mathrm{K}$ digestion, probe size and concentration, hybridization temperature, stringency of washing and method of detection to the specific application.

\subsubsection{Proteinase K digestion}

The main hitch of the in situ hybridization technique lies in the fact that the nucleic acids are bound inside a complex matrix of cellular structures, so that the target sequences are not readily accessible to the labelled probes. Therefore, the target RNA molecules were releaved by proteinase $\mathrm{K}$ digestion, which is the most critical step in the whole in situ hybridization procedure. The time and the temperature of the incubation and the amount of the enzyme have to be optimised for each tissue section type. With too little digestion, the cytoplasmatic membranes will not be sufficiently permeable to probes. With too much digestion, the membranes and protein structures will lose integrity and the template RNA or the hybrid complex may leak out of the cells and make surrounding cells falsely positive. Other adverse consequences can include high background and poor morphology. As determined experimentally, 1-2 $\mu \mathrm{m}$ thick, paraffin-embedded adrenal tissue requires $14 \mu \mathrm{g} / \mathrm{ml}$ proteinase $\mathrm{K}$ for $30 \mathrm{~min}$ at $37^{\circ} \mathrm{C}$.

\subsubsection{Probes}

The choice of length depends on the intended target. When there are low levels of target (as is usually the case), long riboprobes are usually used as they are more sensitive. Because of problems with probe penetration when using intact cells or tissue, shorter probes give more rapid hybridization in situ, as they can easily gain access to the targets. The length of the probes is also dependent on the chosen specific part of the respective sequence. Probes of 201-668 base pairs in length were used in this study. 


\begin{tabular}{|c|cc|c|c|}
\hline Transporter & \multicolumn{2}{|c|}{ Position and length of riboprobe } & $\begin{array}{c}\text { Hybridization } \\
\text { temperature }\end{array}$ & Concentration \\
\hline OAT1 & $1318-1559$ & 241 base pairs & $55^{\circ} \mathrm{C}$ & $10 \mu \mathrm{g} / \mathrm{ml}$ \\
\hline OCT1 & $1630-1831$ & 201 base pairs & $45-50^{\circ} \mathrm{C}$ & $10-20 \mu \mathrm{g} / \mathrm{ml}$ \\
\hline OCT2 & $1701-2009$ & 298 base pairs & $53^{\circ} \mathrm{C}$ & $14 \mu \mathrm{g} / \mathrm{ml}$ \\
\hline oatp1 & $2074-2682$ & 608 base pairs & $50^{\circ} \mathrm{C}$ & $8 \mu \mathrm{g} / \mathrm{ml}$ \\
\hline oatp2 & $2096-2764$ & 668 base pairs & $50^{\circ} \mathrm{C}$ & $8 \mu \mathrm{g} / \mathrm{ml}$ \\
\hline oatp3 & $678-958$ & 320 base pairs & $55^{\circ} \mathrm{C}$ & $10 \mu \mathrm{g} / \mathrm{ml}$ \\
\hline
\end{tabular}

Table 8. The size and concentration of the riboprobes used for in situ hybridization. Numbers denote position of the first and last nucleic acid of the sequence and the length. The optimal concentrations determined experimentally are listed in this table.

Molecules used to label the probe for detection can further compromise penetration of the probe into the cells. These molecules can increase the rigidity of the probe, increase the steric hindrance, and adversely affect charge density and the distribution of the probe. The proper probe concentration must be also determined to give the best signal to background ratio (Table 8).

The chosen part of the of the respective sequence was amplified by PCR with proofreading polymerase from rat adrenal cDNA (see 3.4.2). The amplified DNA fragment was cloned into into pPCR-Script vector containing T3 and T7 RNA polymerase promoters. To generate labelled RNA probes, in vitro transcription was performed using the previously prepared DNA template, DIG-RNA Labelling Mix (Roche) and T3 or T7 RNA polymerases (see 3.13.1).

\subsubsection{Hybridization temperature and time}

Stringent hybridization conditions were used to achieve high specificity and low background. This means high annealing temperature (between $50-55^{\circ} \mathrm{C}$ ). Low salt concentration was used in the hybridization mixture, which means high stringency at any temperature. Long incubation time (overnight) was used with the experimentally determined probe concentration. 


\subsubsection{Washing}

For washing after hybridization also stringent conditions were favoured. To remove probes bound to fatty acids, lipids and proteins, washing buffers with low salt concentration and soap basis were used (see 2.3). To increase stringency, the second washing step was carried out at the hybridization temperature.

\subsubsection{Detection}

All tissues have a certain level of endogenous enzyme activity (peroxidase, phosphatase etc.), and this can increase non-specific background levels. To avoid this, it is needed to choose an adequate enzyme-based detection system and/or pre-treat the tissue to remove or inhibit the endogenous enzymes. In the case of the adrenal gland, a kidney alkaline phosphatase-based detection system and pre-treatment with acetic anhydride were chosen (see 3.13.2).

\subsubsection{Controls for in situ hybridization}

Controls should be included to monitor the hybridization reaction for probe specificity and to assess the level of background. In this study, sense probes were used as controls which were generated from the same DNA sequence labelled with DIG-dUTP and also the hybridization conditions were the same as for the respective antisense probes.

\subsubsection{Expression pattern of the newly demonstrated organic anion transporters in the rat adrenal}

The homology cloning PCR technique disclosed the presence of ROAT1, oatp1, oatp2 and oatp3 in rat adrenal cDNA. This means the presence of two organic transporter families with similar function but divergent substrate specificity and of which the oatp family is present with more members. This raises the questions of occurrence, functional role or rather the division of labour. Then non-radioactive in situ 
hybridization method was chosen to detect the regions of expression of the investigated transporters. On the basis of the above detailed description, the method was optimized for every single probe to find out the optimal conditions for the most specific hybridization (Table 8.).

A

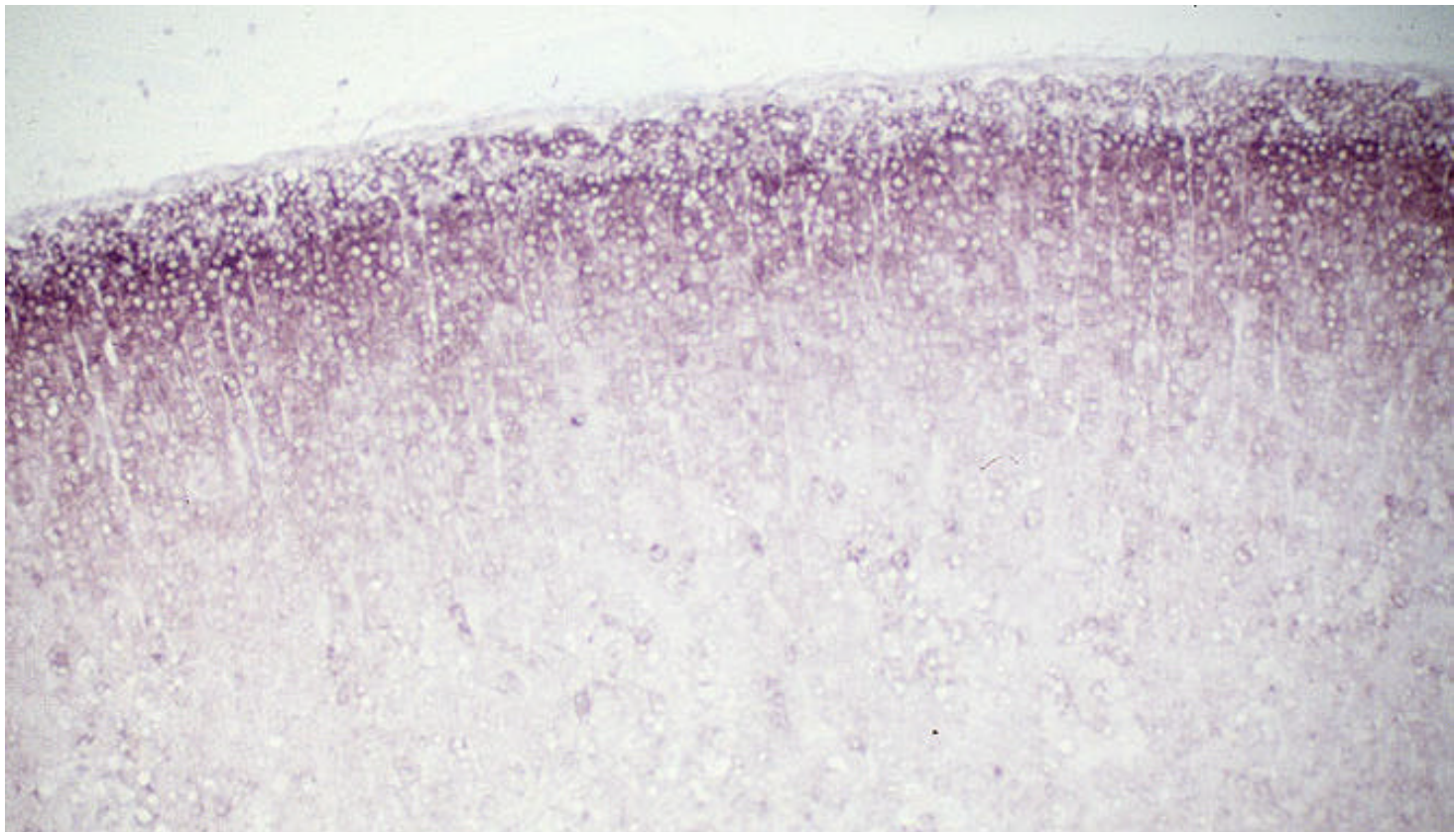

B

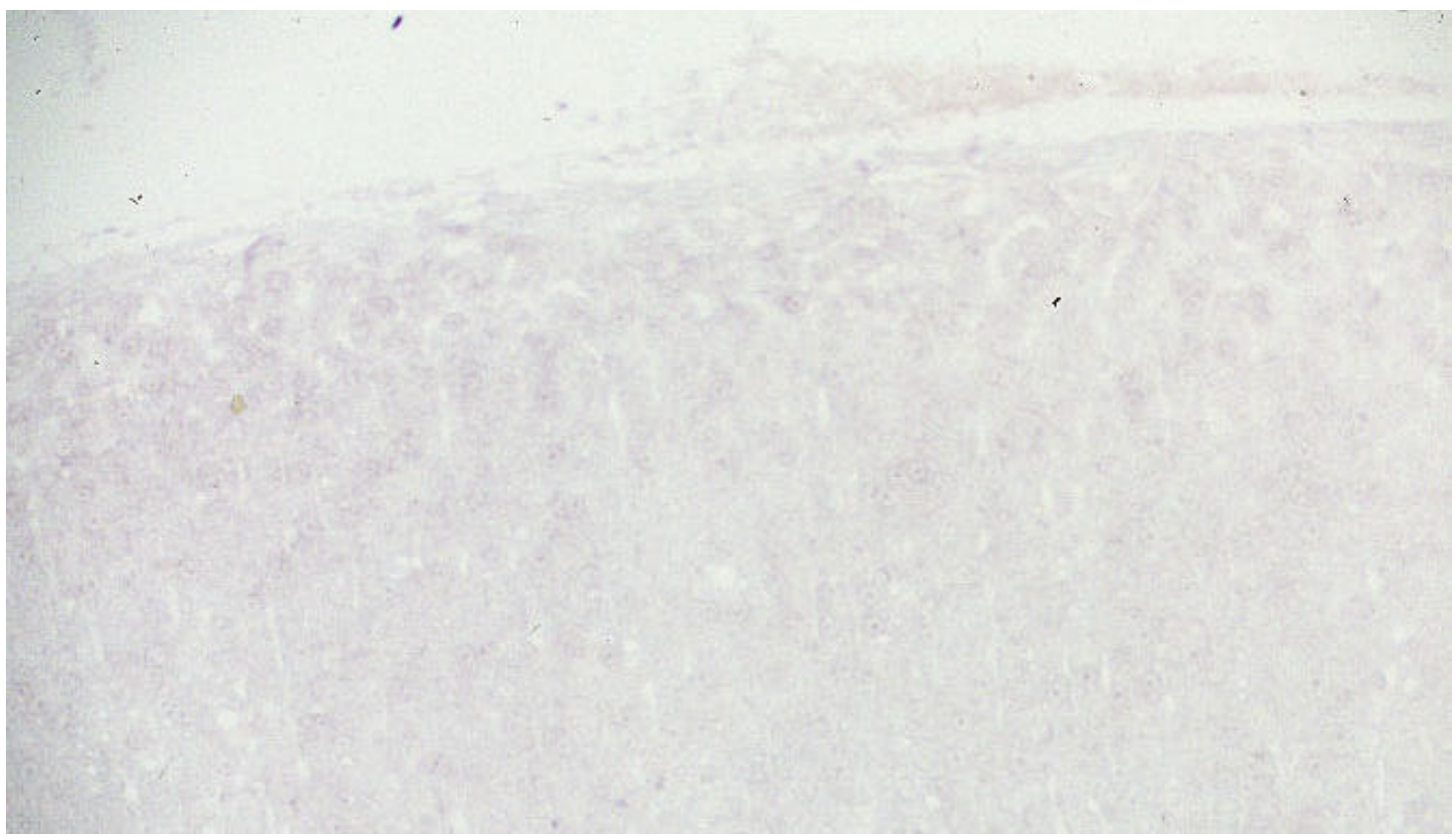

Picture 4. In situ hybridization of rat adrenal sections with digoxigenin (DIG)-labelled rat ROAT1 probe from control animals. ROAT1 mRNA was expressed in the outer zona fasciculata. A., antisense B., sense 
A

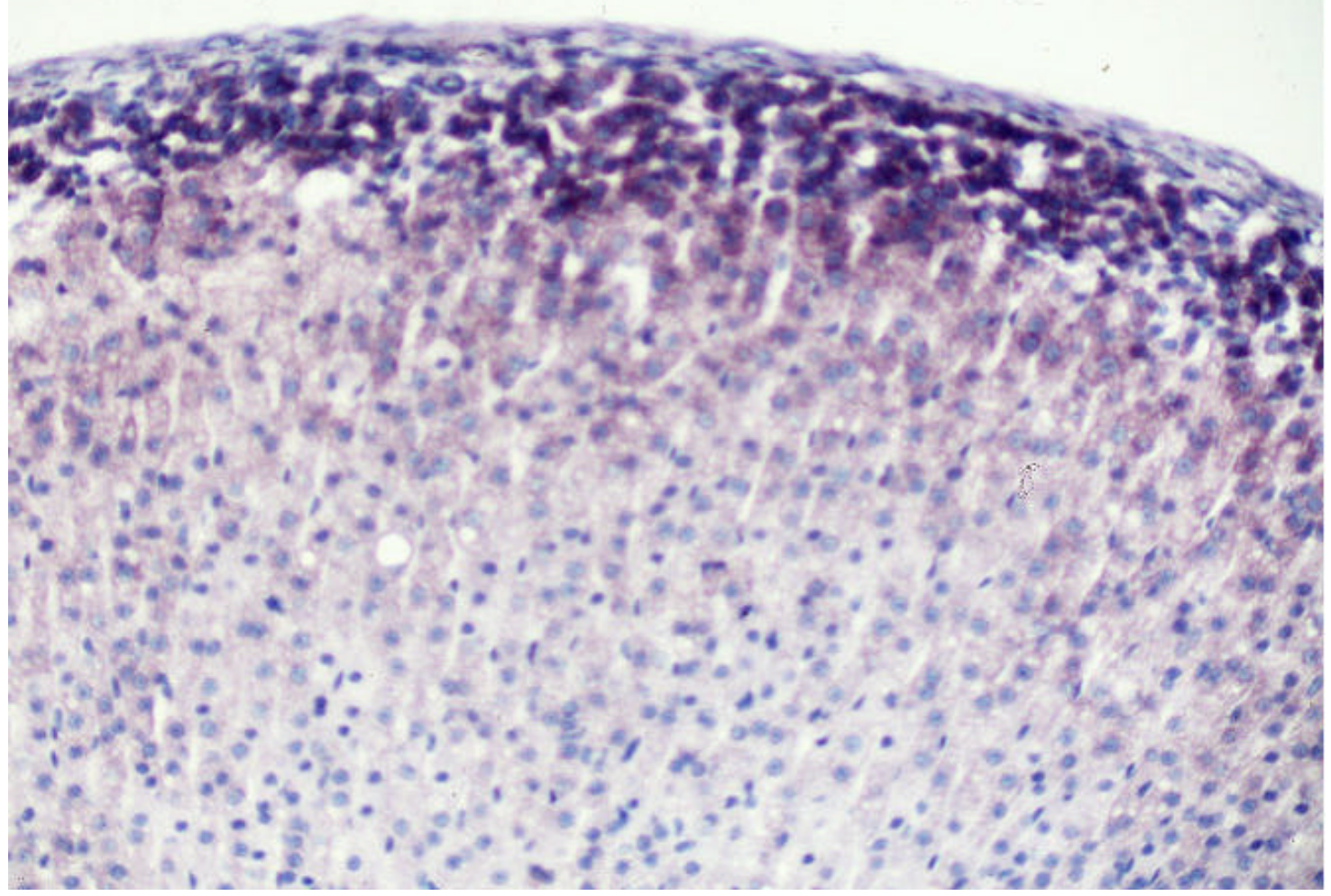

B

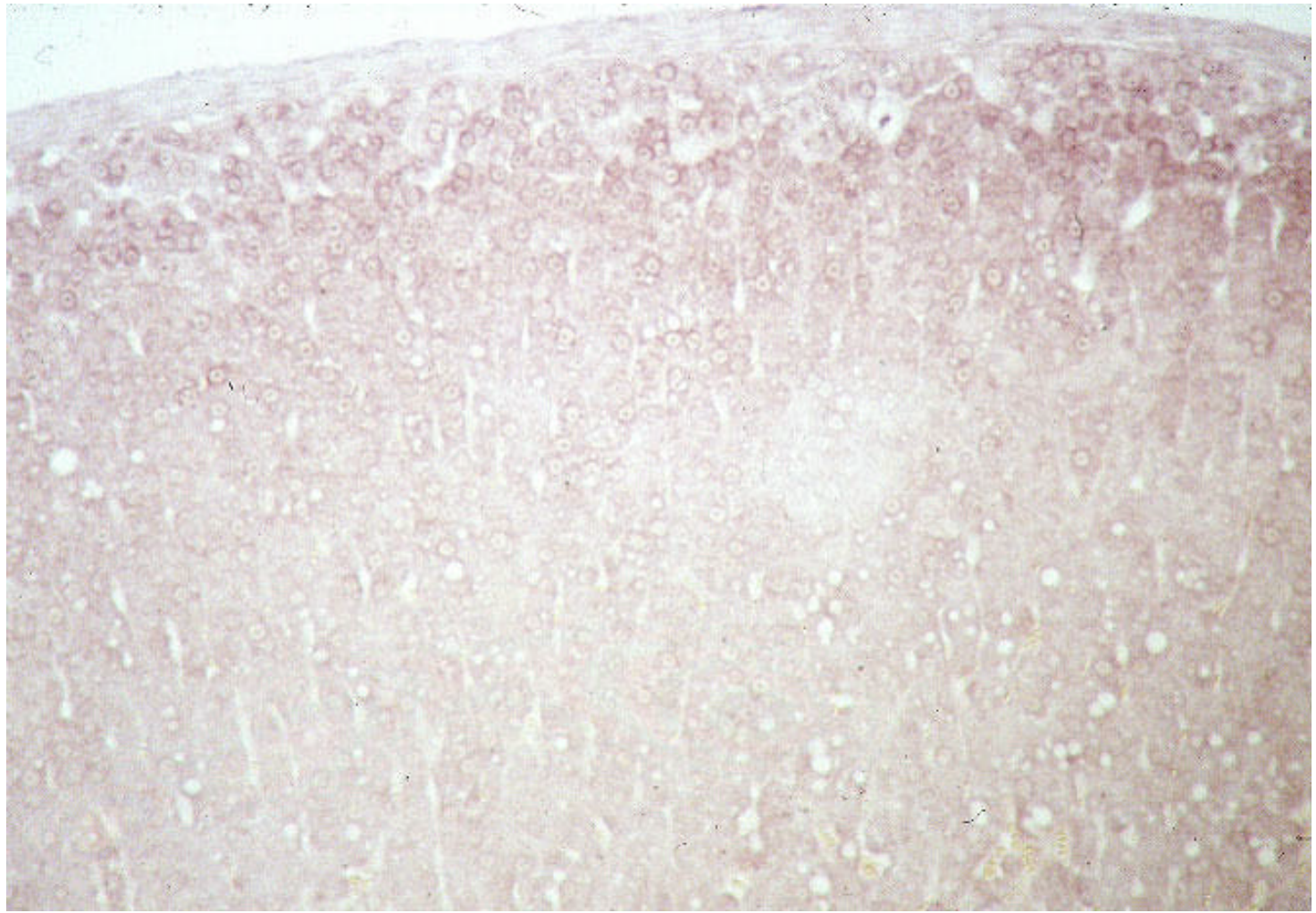

Picture 5. In situ hybridization of rat adrenal sections with DIG-labelled rat oatp3 probe from control animals. The expression of oatp3 mRNA was observed in the zona glomerulosa. A., antisense B., sense 
A

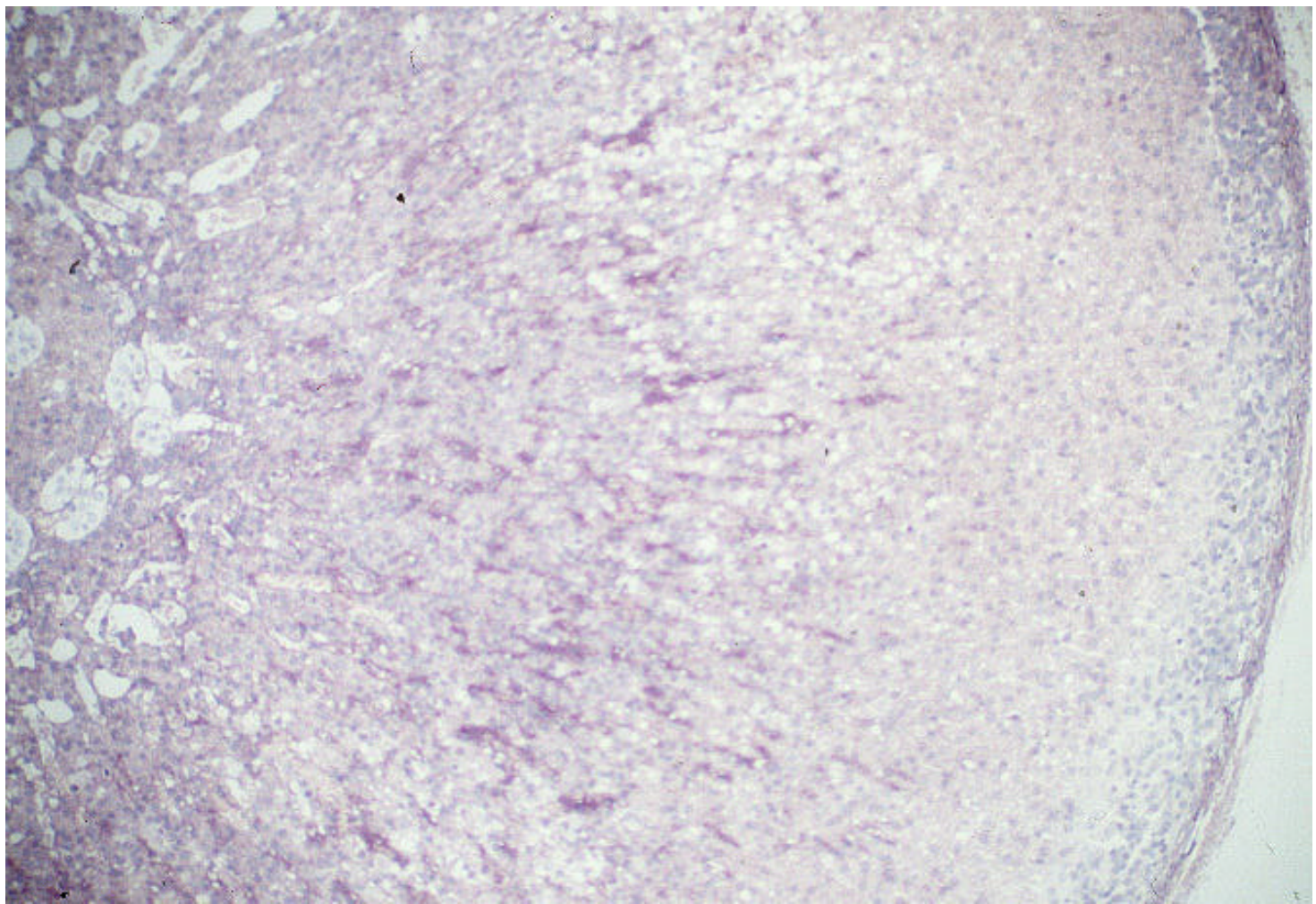

B



Picture 6. In situ hybridization of rat adrenal sections with DIG-labelled rat oatp1 probe from control animal. The expression of oat $1 \mathrm{mRNA}$ was observed in the inner zona fasciculata and zona reticularis. A., antisense B., sense 
A

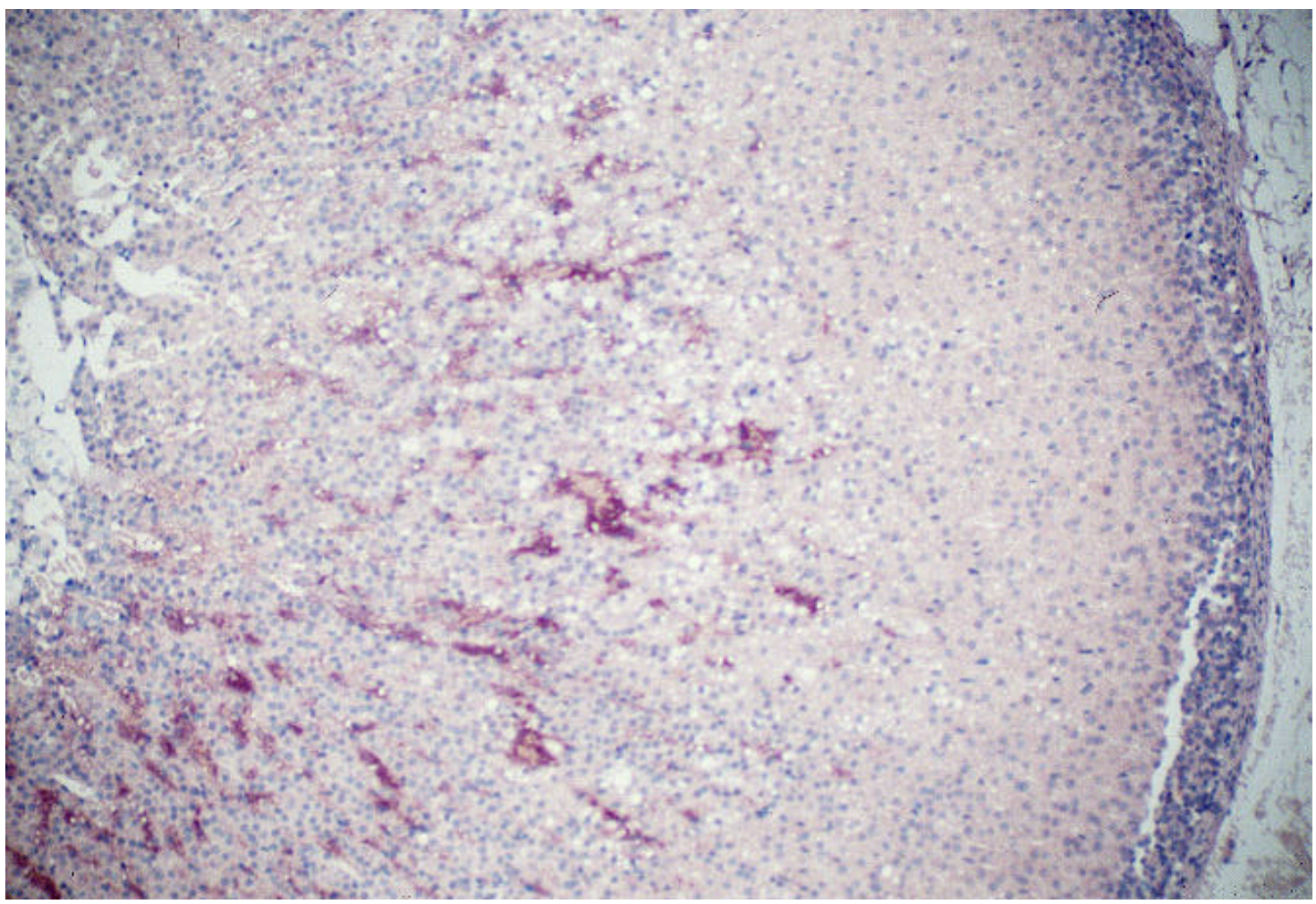

B



Picture 7. In situ hybridization of rat adrenal sections with DIG-labelled rat oatp2 probe from control animals. The expression oatp2 mRNA was observed in the inner zona fasciculata and zona reticularis. A., antisense B., sense 
During the in situ hybridization studies, cis-inhibition transport assays were published with the recently cloned rat organic cation transporters 1 and 2. Among others, corticosterone decreased, in physiological concentration, organic cation transport via OCT2. In co-operation with Prof. Koepsell, organic cation transporter 1 (OCT1) and 2 (OCT2) probes which had already been used for in situ hybridization in kidney, were tested in rat adrenal gland for the presence of this cation transporters.

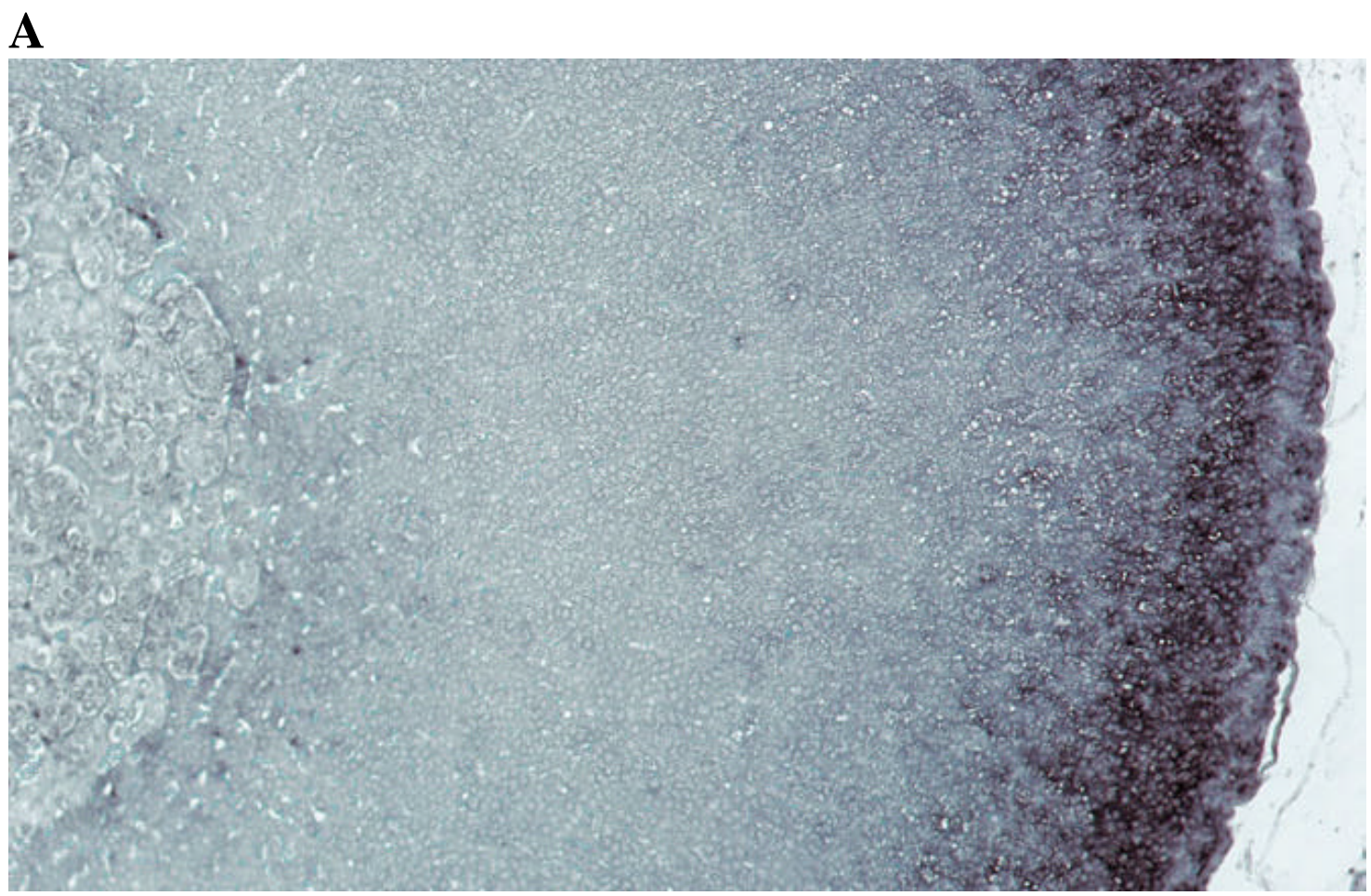

B

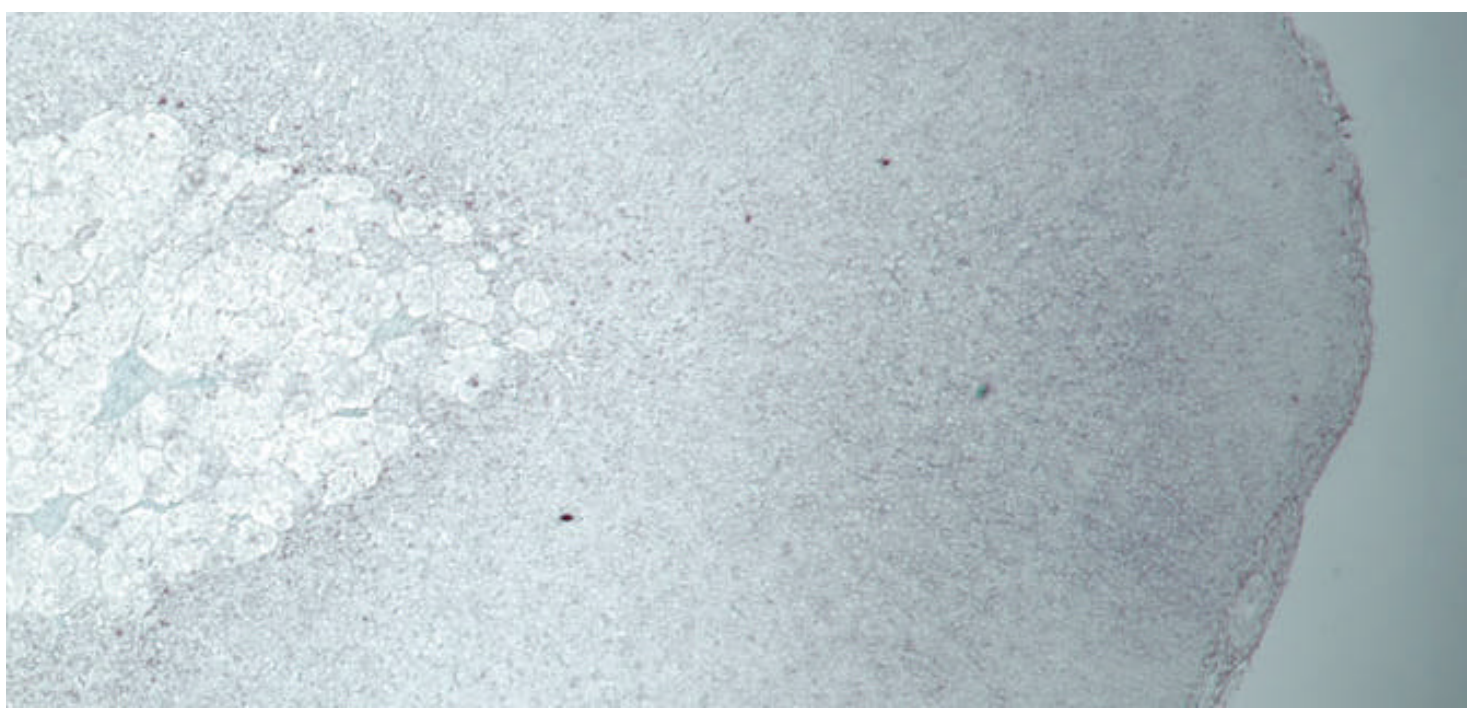

Picture 8. In situ hybridization of rat adrenal sections with DIG-labelled rat OCT2 probe from control animals. OCT2 mRNA was expressed in the zona glomerulosa and in the outer zona fasciculata. A., antisense B., sense 


\begin{tabular}{|c|c|c|c|c|}
\hline Transporter & $\begin{array}{c}\text { Zona } \\
\text { glomerulosa }\end{array}$ & $\begin{array}{c}\text { Outer zona } \\
\text { fasciculata }\end{array}$ & $\begin{array}{c}\text { Inner zona } \\
\text { fasciculata }\end{array}$ & Zona reticularis \\
\hline OAT1 & - & ++ & - & - \\
\hline oatp1 & - & - & + & + \\
\hline oatp2 & - & - & + & - \\
\hline oatp3 & ++ & - & - & - \\
\hline OCT1 & - & - & - & - \\
\hline OCT2 & ++ & ++ & - & - \\
\hline
\end{tabular}

Table 9. Expression zonation of the investigated transporters in the adrenal gland. Dig-labelled RNA probes, typical of the studied transporter, were used in adjusted in situ hybridisation to detect the expression appearance and division of these transporters. - - means there was no signal + , means single cells were positive ++ , means the whole zone was positive.

The results of the in situ hybridization confirmed that the investigated transporters were expressed separated and zone specific. Construing the in situ hybridization data and comparing them with the characterization of the transporters, a close relation is suggested in some cases between the product of the certain adrenal zone and the transporter expressed there. In detail, ROAT1 is expressed in the whole outer zona fasciculata, and corticosterone was produced without stimulation exclusively by the outer zona fasciculata according to the recent investigations. The zona glomerulosa produces aldosterone and ouabain and oatp3 and OCT2 was found in this zone. There are no experimental data whether there is any interaction between these steroids and transporters, but the common occurrence renders it probable. The point of interest is that OCT2 is also present in the outer zona fasciculata which produces corticosterone, a possible substrate of the transporter. The expression of the other two members of the organic anion transporter family (oatp1 and oatp2) turned out spotty in the inner zona fasciculata and zona reticularis. The positive cells were found mostly around vessels in one or two cell rows. These zones produce mainly conjugated steroids, sexual steroids and dehydroepiandrosterone(sulphate), which have been shown to interact with the above mentioned transporters. OCT1 gave no signal in the adrenal gland, not even when lower hybridization temperatures $\left(45-50^{\circ} \mathrm{C}\right)$, higher template concentrations (10$20 \mu \mathrm{g} / \mathrm{ml}$ ) and increased proteinase $\mathrm{K}$ amount (up to $20 \mu \mathrm{g} / \mathrm{ml}$ ) were tried. However the negative result of the in situ hybridization was not confirmed with other methods. 


\subsubsection{Localisation of oatp3 in rat kidney}

As oatp3 was a transporter from rat retina newly discovered during this study and only Northern blot analysis demonstrated its presence in the kidney, the localization of oatp3 expression in the kidney was a current issue. The previously used oatp3-RNA probes were employed on perfused rat kidney sections prepared by the group of Prof. Kaissling, Department of Anatomy, University of Zürich.

A

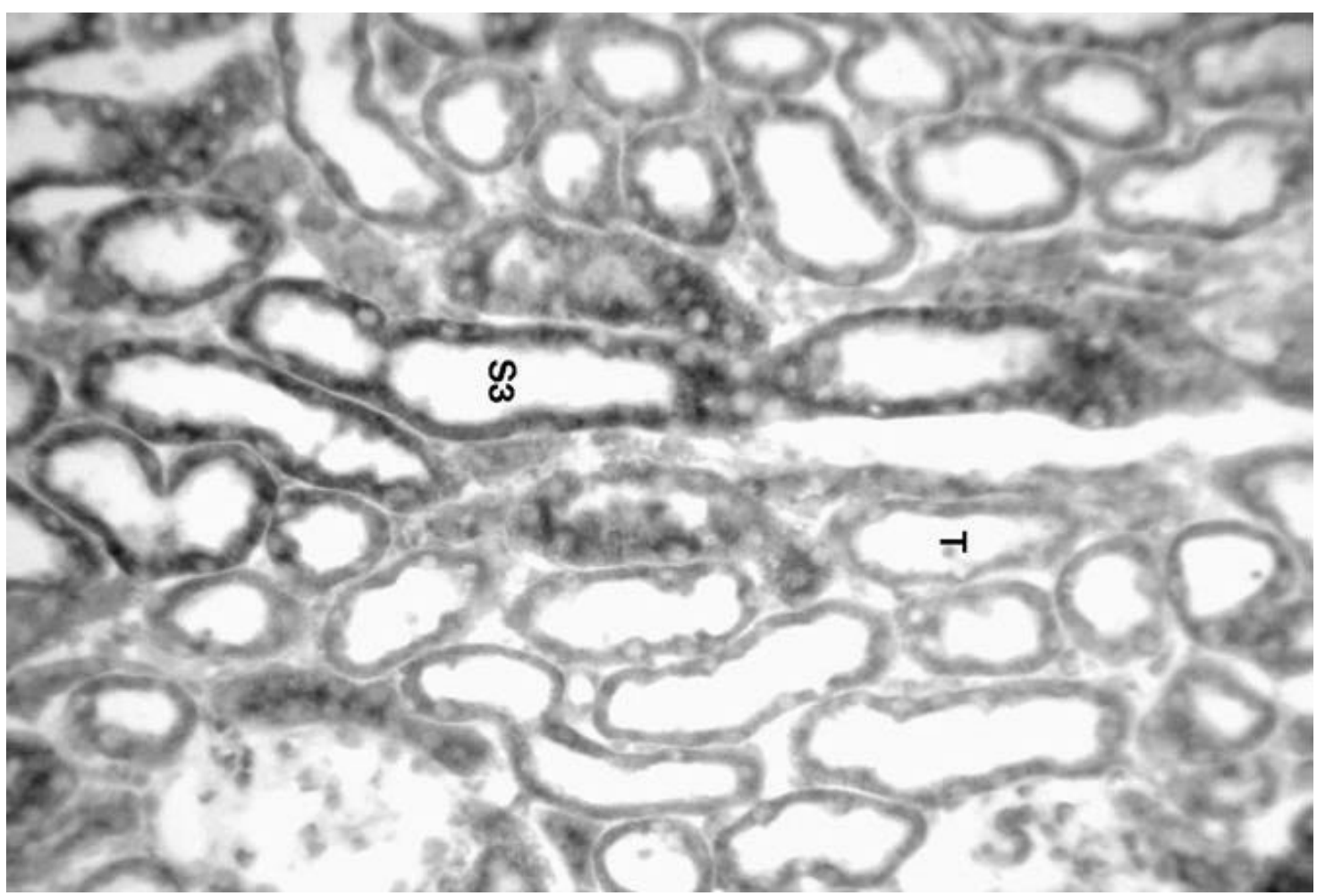

B

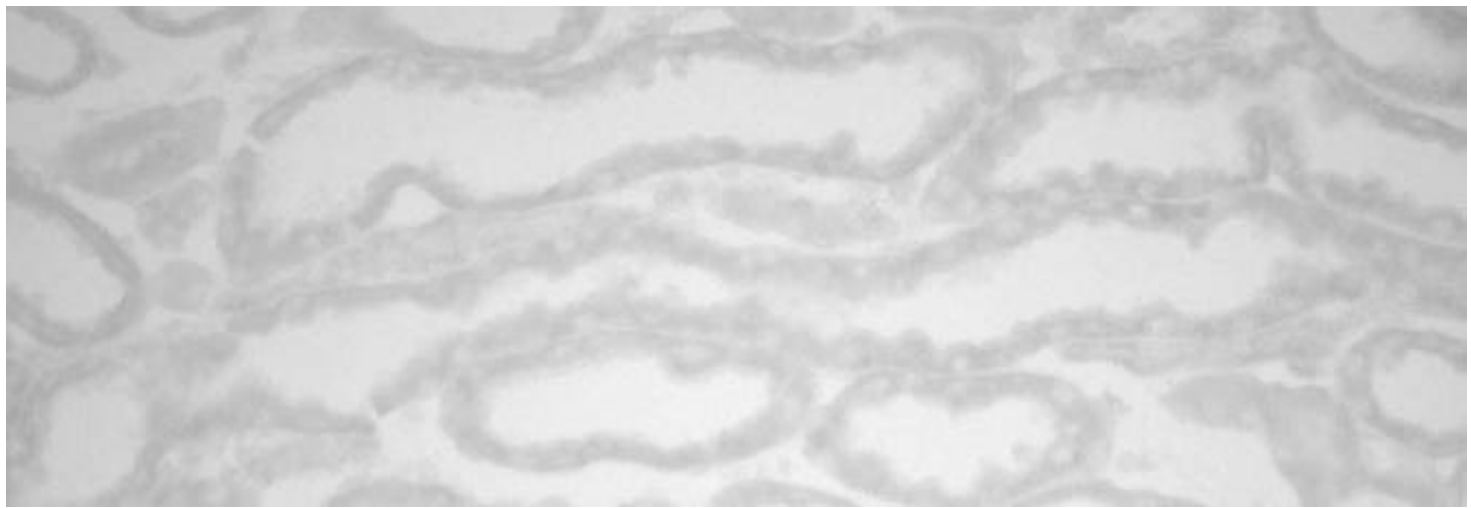

Picture 9. In situ hybridization of perfused rat kidney sections with DIG-labelled rat oatp3 probe from control animals. The expression of oatp3 was observed in the S3 segment of the proximal tubule. T: Thin ascending limb of Henle's loop, A.,antisense B.; sense 
This result was an additional proof of the existence of this transporter in the kidney, and the expression was restricted to the $\mathrm{S} 3$ segment of the proximal tubules.

\subsubsection{Hormone regulation of the expressed transporters in the adrenal gland}

The renal organic anion transporter (ROAT1) localizes exactly in the same zone as the 11- $\beta$ hydroxylase, the end enzyme of corticosterone synthesis. Thus, the in situ hybridization result supports the previous assumption that this transporter might be involved in cortisol or corticosterone transport. It is known that ACTH controls corticosterone production and release. This effect is mediated by an increase in the number of 11- $\beta$ hydroxylase enzyme molecules in the cells and in the whole adrenal gland. Under basal conditions, the enzyme is expressed only in the outer zona fasciculata, but under the influence of ACTH the inner zona fasciculata and zona reticularis cells also start to express the enzyme and in connection with it, the corticosterone production is also increased. Moreover, some glomerulosa cells change into fasciculata cells and they also start to express the hydroxylase enzyme and produce corticosterone. The idea was that if the transporter is involved in glucocorticoid transport, ACTH should have a regulatory effect on the expression of the transporter, similar to that on the enzyme. To find out whether ACTH has any effect on the expression of the transporter, rats were treated with ACTH (Synacten) for 5 days, other rats were hypophysectomized to investigate the effect of the lack of ACTH. All three groups were injected, including the control group, at the same time (the hypophysectomized and control rats were injected with $0.9 \%$ saline solution) to correct for errors caused by stress. This was very important as corticosterone is a so-called stress hormone, which is increased during stress. After treatment, the animals were killed and the adrenal glands were prepared for in situ hybridization and blood was taken to measure the corticosterone concentration with a radioimmunoassay (Figure 11.). 


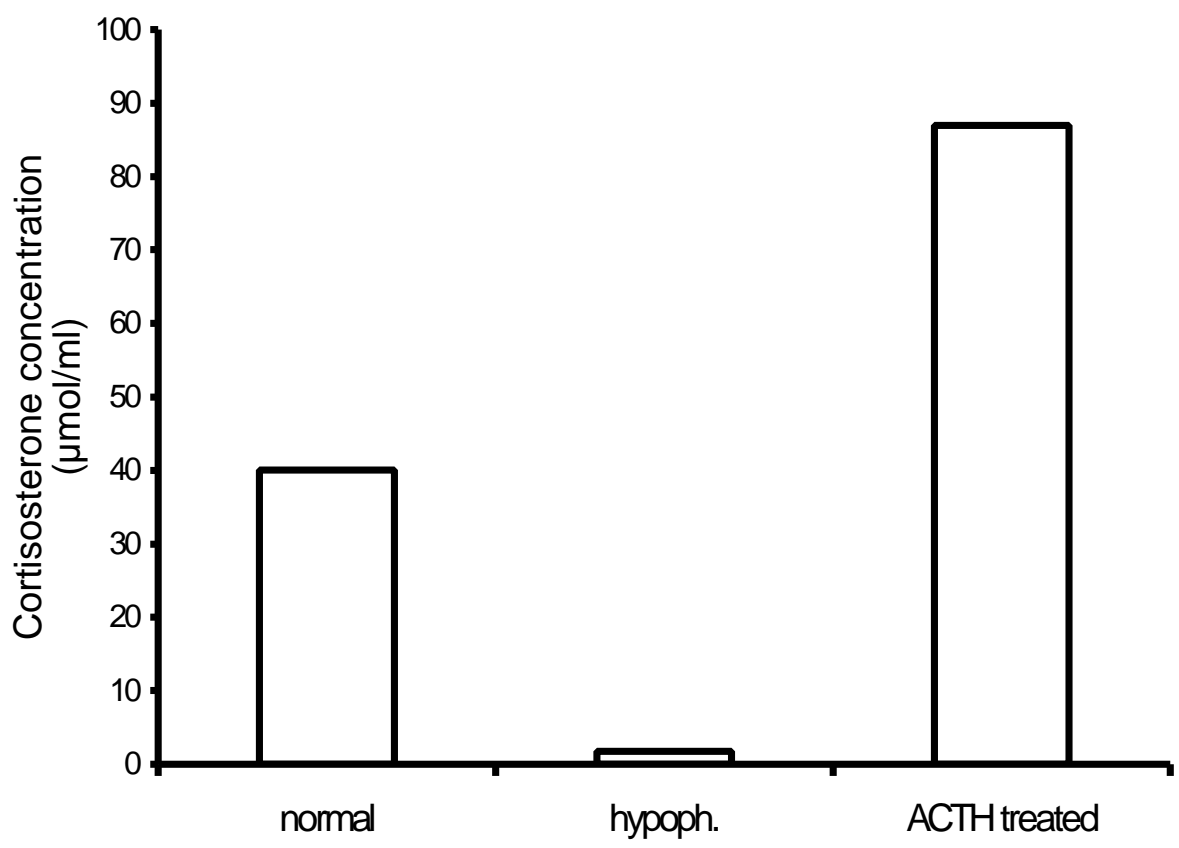

Figure 11. Corticosterone concentration in the blood of the treated rats. The rat was treated with ACTH (2.5 U Synacten) for 5 days, another rat was hypophysectomized to investigate the effect of the lack of ACTH. The hypophysectomized and control rats were injected with $0.9 \%$ saline solution at the same time as the ACTH treated ones. The concentration of corticosterone was determined by RIA.

\subsubsection{ACTH regulation of ROAT1 expression in the adrenals}

The regulation of ACTH on the rat "renal" organic anion transporter (ROAT1) was unambiguous. The effect was an obvious change in the expression pattern. In the hypophysectomized adrenal gland the expression of this transporter was no longer detectable (Picture 11.), while under normal, non-induced conditions the localization of the ROAT1 was limited to the outer zona fasciculata (Picture 4.). After ACTH treatment, modelling an induced state of corticonsterone synthesis, the localization was dramatically changed, spreading to other zones of the adrenal cortex. Strong signals were demonstrated in the inner zona fasciculata, zona reticularis and zona glomerulosa (Picture 10.). 


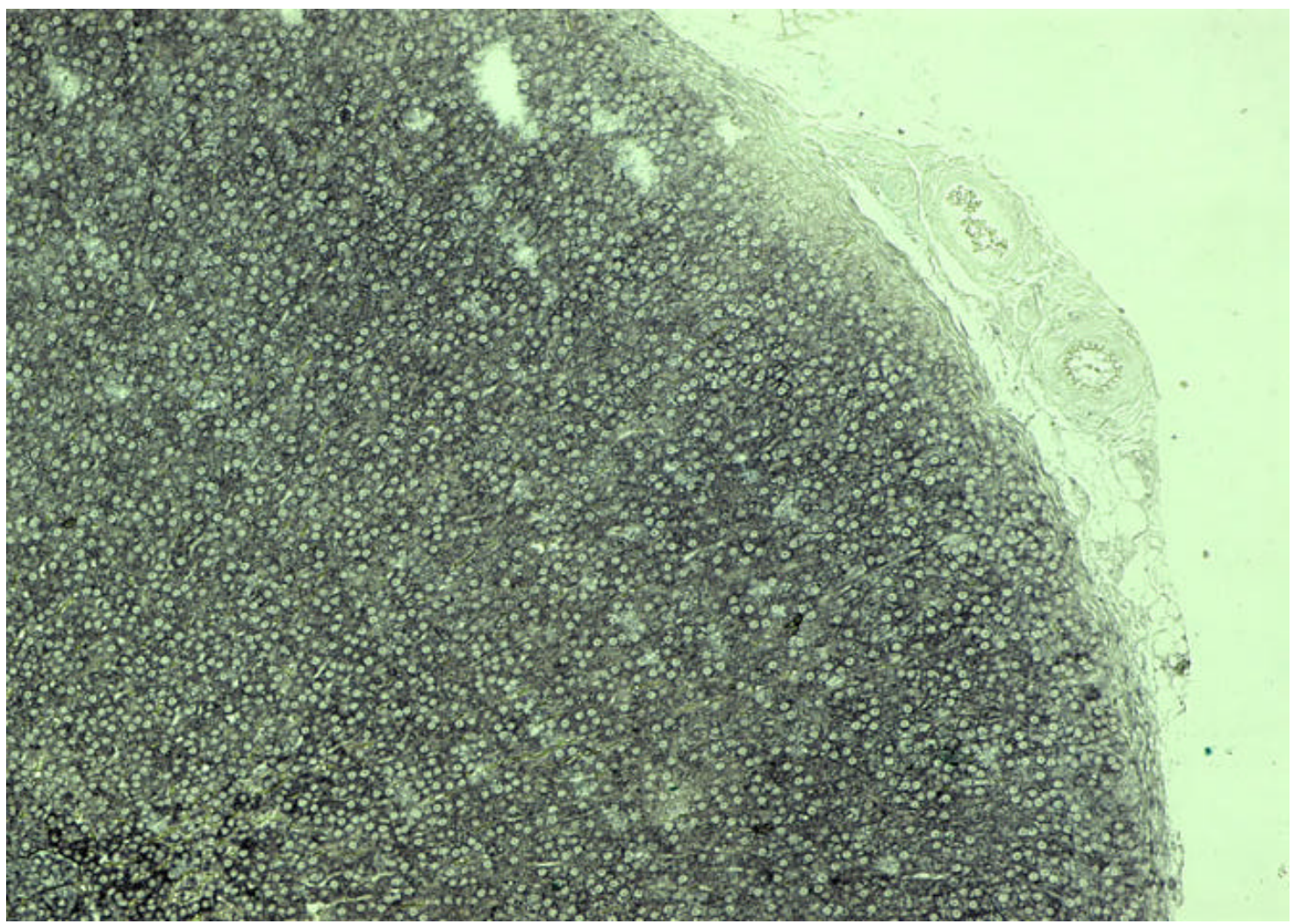

Picture 10. In situ hybridization of rat adrenal section with DIG-labelled ROAT1 probe from animals after ACTH treatment for 5 days. The expression of ROAT1 mRNA was enhanced particularly in the inner zona fasciculata and zona reticularis. Also zona fasciculata cells abutted directly against the connective tissue capsule

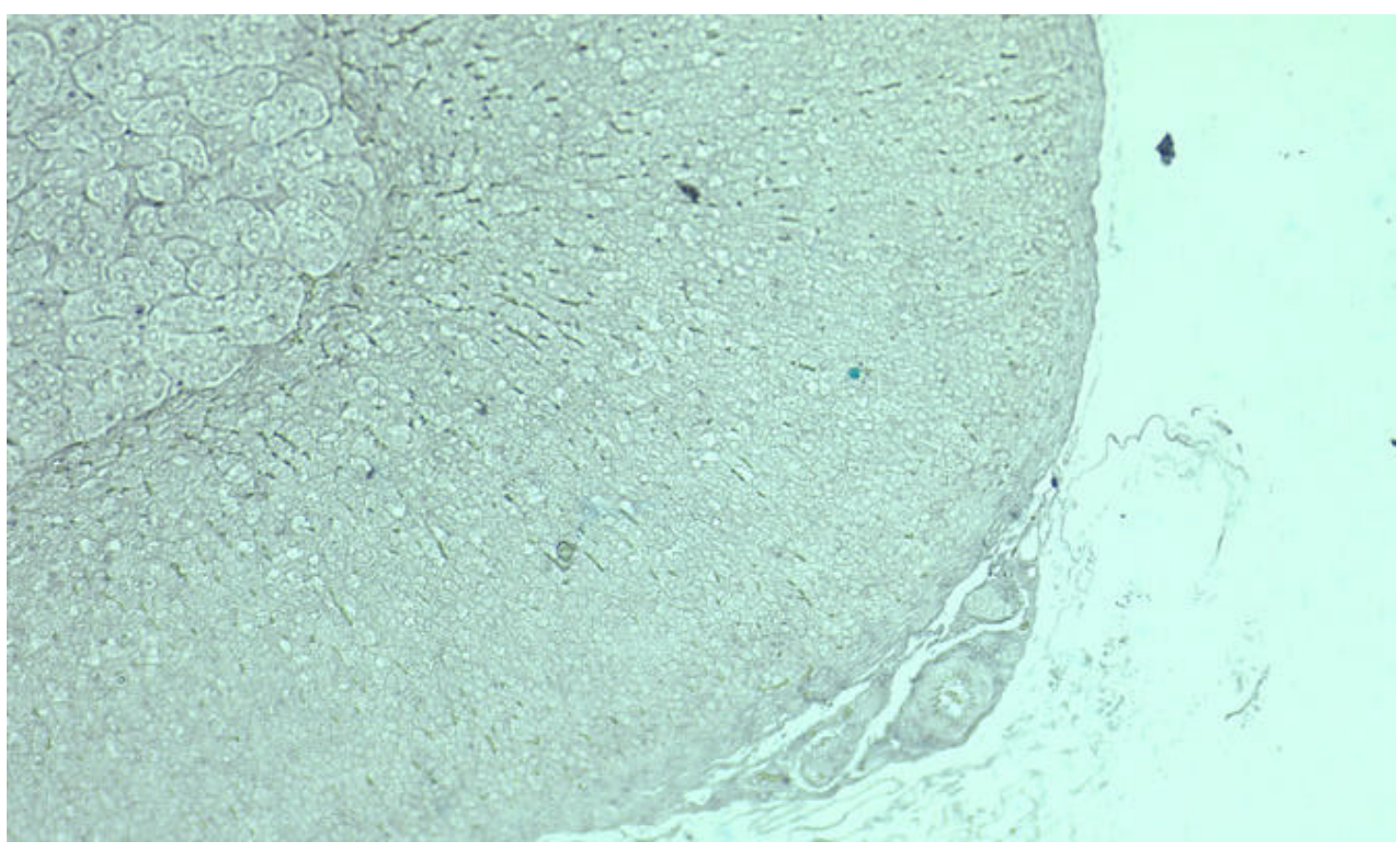

Picture 11. In situ hybridization of rat adrenal section with DIG-labelled ROAT1 probe from hypophysectomized animals. No detection of message was observed in the zona glomerulosa, zona fasciculata and zona reticularis. 


\subsubsection{ACTH regulation of oatp3 expression in the adrenals}

Unlike the above transporter, ACTH had no clear effect on oatp3 expression since in comparison with normal conditions, in the hypophysectomized animal the signal was slightly weaker, but still detectable (Picture 13.). No significant change of localization similar to the one mentioned above was revealed. After the ACTH treatment, only the intensity of signals increased (Picture 12.)



Picture 12. In situ hybridization of rat adrenal section with DIG-labelled oatp3 probe from animals treated with ACTH for 5 days.

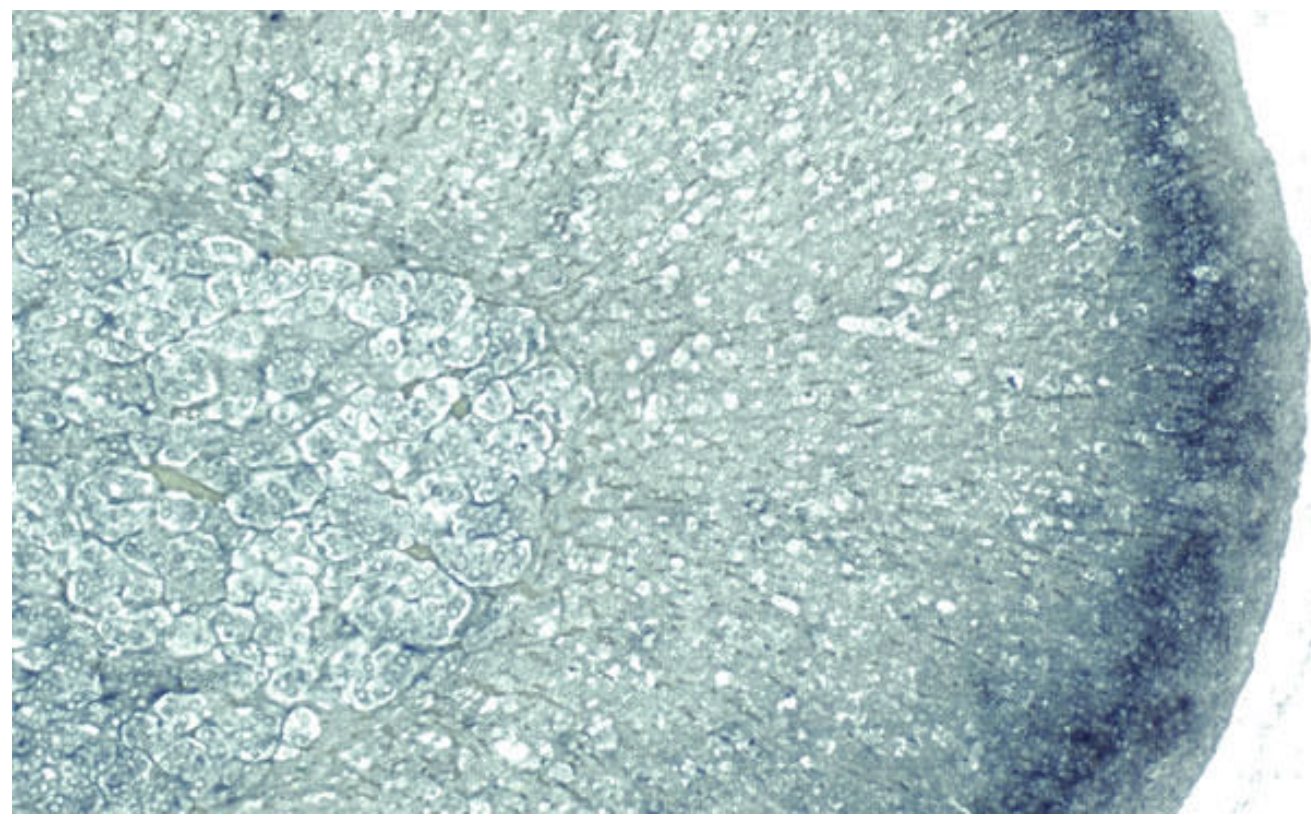

Picture 13. In situ hybridization of rat adrenal section with DIG-labelled oatp3 probe from hypophysectomised animals. 


\subsubsection{ACTH regulation of OCT2 expression in the adrenals}

The effect of ACTH on the expression pattern of OCT2 was similar to oatp3. In hypophysectomized animals the signal became weaker (Picture 15.). The ACTH treatment resulted in small change of localisation and increased intensity (Picture 14.).

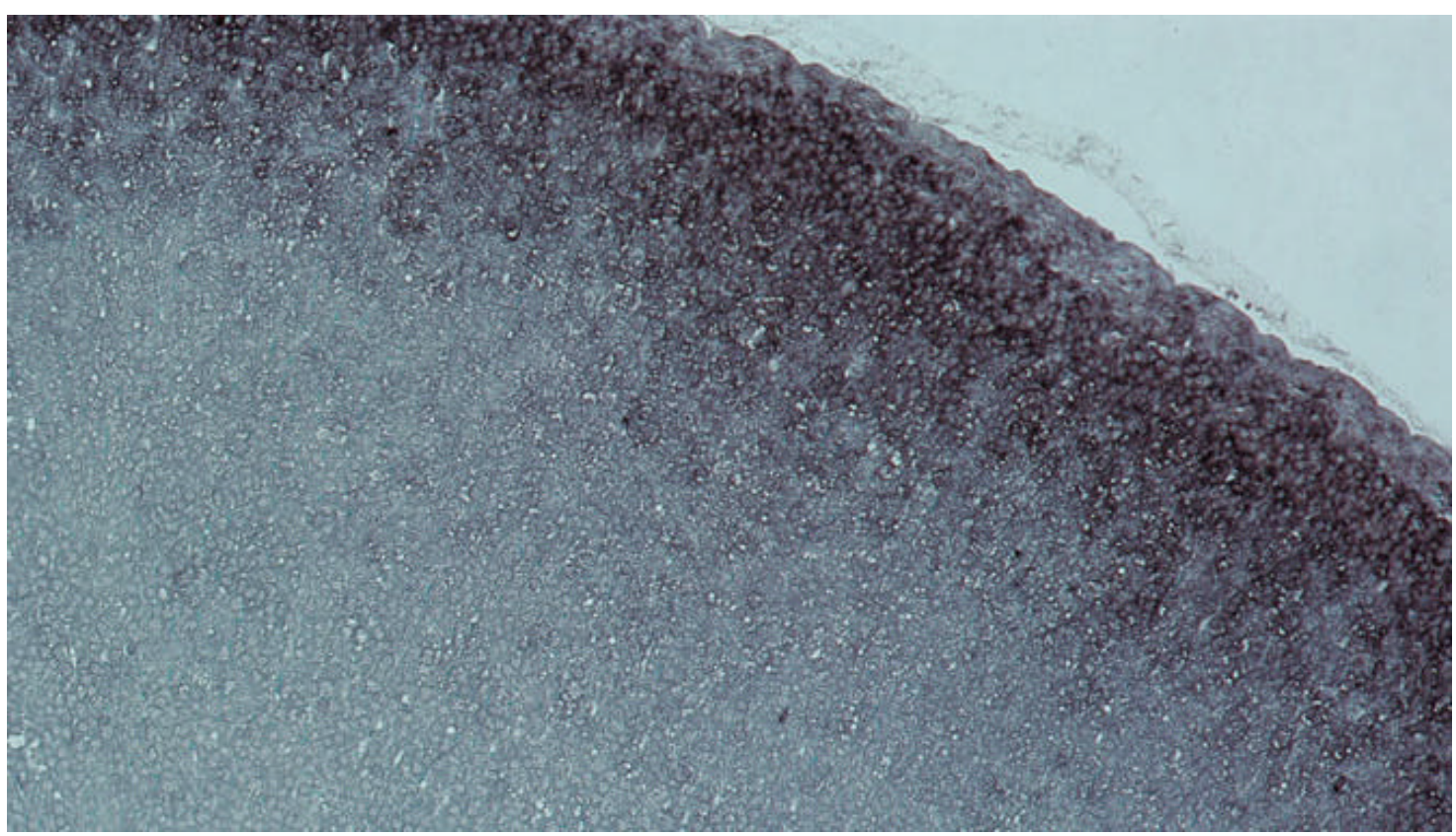

Picture 14. In situ hybridization of rat adrenal section with DIG-labelled OCT2 probe from animals after ACTH treatment for 5 days.

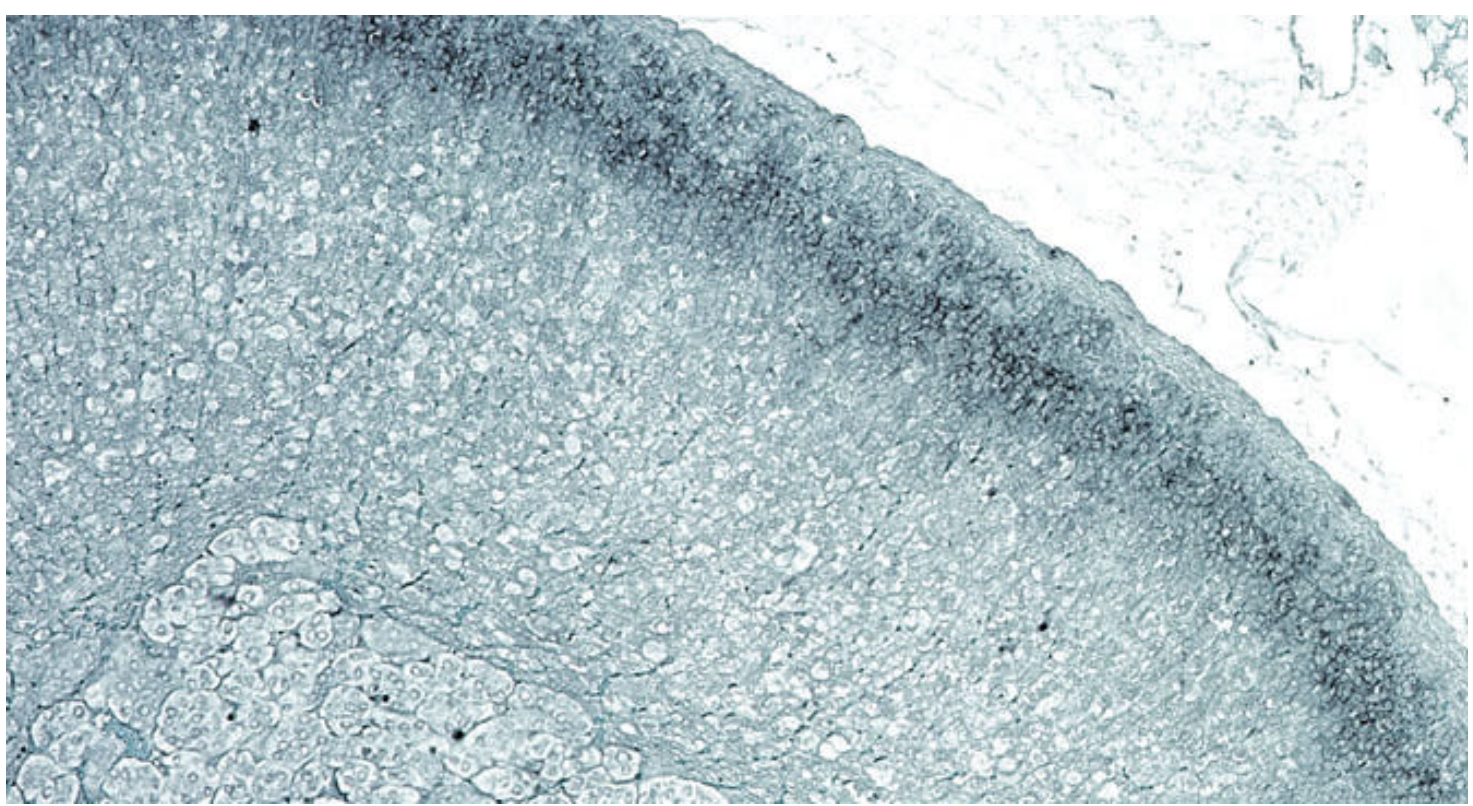

Picture 15. In situ hybridization of rat adrenal section with DIG-labelled OCT2 probe from hypophysectomized animals. 


\subsection{FUNCTIONAL CLONE OF OATP3}

The organic anion transporting polypeptide 3 (oatp3) was originally cloned from a rat retinal cDNA library and Northern Blot analysis revealed it in kidney, too. In the present study, the transporter was also shown in the adrenal gland by a homology cloning PCR technique and in situ hybridization. The exclusive expressional appearance in the adrenal gland was in zona glomerulosa cells and in the kidney in the S3 segment of the proximal tubule. Since this transporter was newly discovered and poorly characterized, demand arose for further functional characterization. The whole open reading frame was amplified from rat adrenal cDNA by a proof reading polymerase. Performing the PCR reaction, the manufacturer's instructions (PowerScript DNA Polymerase, PAN Biotech GMBH, Germany) were followed accurately for the sake of high fidelity. The primers were designed to bind at a high annealing temperature $\left(60^{\circ} \mathrm{C}\right)$, carrying $X b a \mathrm{I}$ and HindIII sites and used in $100 \mathrm{pmol}$ quantity. The denaturation time was kept short $\left(10 \mathrm{sec}\right.$ at $\left.94^{\circ} \mathrm{C}\right)$ and 25 cycles were run. The PCR product was confirmed by sequencing and cloned into an expression vector, which was used for protein expression in Xenopus laevis oocytes. For expression, both 5' and 3' untranslated regions (UTRs) are necessary for cRNA translation, which, however, were not known for oatp3. That is the reason why the following strategy was used to construct functional clone with modification of a flounder sodium dicarboxylate transporter, fNaDC-3 (Steffgen et al. 1999), which is expressed at high levels in oocytes. A construct was generated which consisted of the oatp3 coding region flanked by the 5'and 3'UTRs of fNaDC-3. In detail, first the HindIII and XbaI sites of the vector were disrupted using site directed mutagenesis, then only the UTRs of fNaDC-3 and the complete vector were amplified by PCR. The primers included HindIII and $\mathrm{XbaI}$ restriction sites as close as was practical to the start and stop codons to enable subsequent subcloning. Both the amplification product of the vector and the oatp3 coding region were then sequentially digested with HindIII and XbaI and ligated together. 


\subsubsection{Functional characterization of oatp3}

The function of oatp3 was investigated by injection of Xenopus laevis oocytes with cRNA derived from the expression clone described above. As model substrate, ${ }^{14} \mathrm{C}$ taurocholate $(20 \mu \mathrm{M})$ was given $(10 \mathrm{~min})$ to control its functional integrity, according to Abe et al. 1998, but this failed as there was no more uptake in the injected oocytes compared to the control (water injected) oocytes.

As a second attempt, the clone was subjected to control examinations, checking alignments based on the original sequence from the GenBank and from our labour. The comparison revealed three critical point mutations, which could influence the correct protein folding and could give some reason for the lack of function (App. 1.).

As a third attempt, these three point mutations were changed back to the original nucleotides by site directed mutagenesis. The reactions were carried out with the QuickChange $^{\mathrm{TM}}$ Site-Directed Mutagenesis Kit (Stratagene) following the manufacturer's instructions (see 3.5). The amplification products were verified by sequencing, whether the modification was successful. After the third mutation was corrected, this repaired clone was newly expressed again, but was still non-functional.

\subsection{HUMAN ADRENOCORTICAL CELL LINE}

The bovine and rat experimental results confirmed the original assumption that transporters are involved in the release of steroid hormones. In glucocorticoid release, the participation of the renal PAH transporter is strongly suggested, at least in bovine and rat adrenal. To find out whether the same model can be applied to humans, a steroid producing human adrenocortical carcinoma cell line (NCI-H295) was investigated under different conditions for cortisol release and ${ }^{3} \mathrm{H}-\mathrm{PAH}$ uptake. The H295 cells represent a specific adrenocortical cell line which maintains the ability, under specified conditions, to produce all the adrenocortical steroids (ie., mineralocorticoids, glucocorticoids, and adrenal steroids).

Firstly, the ability of $\mathrm{H} 295$ cells to produce cortisol was evaluated. Cells were initially treated for 24 hours with forskolin $(20 \mu \mathrm{M})$ and the medium content of cortisol was measured by RIA. The production of cortisol increased linearly with time and forskolin stimulation was unambiguous, about fifteen-fold after 24 hours (Figure 12.). 


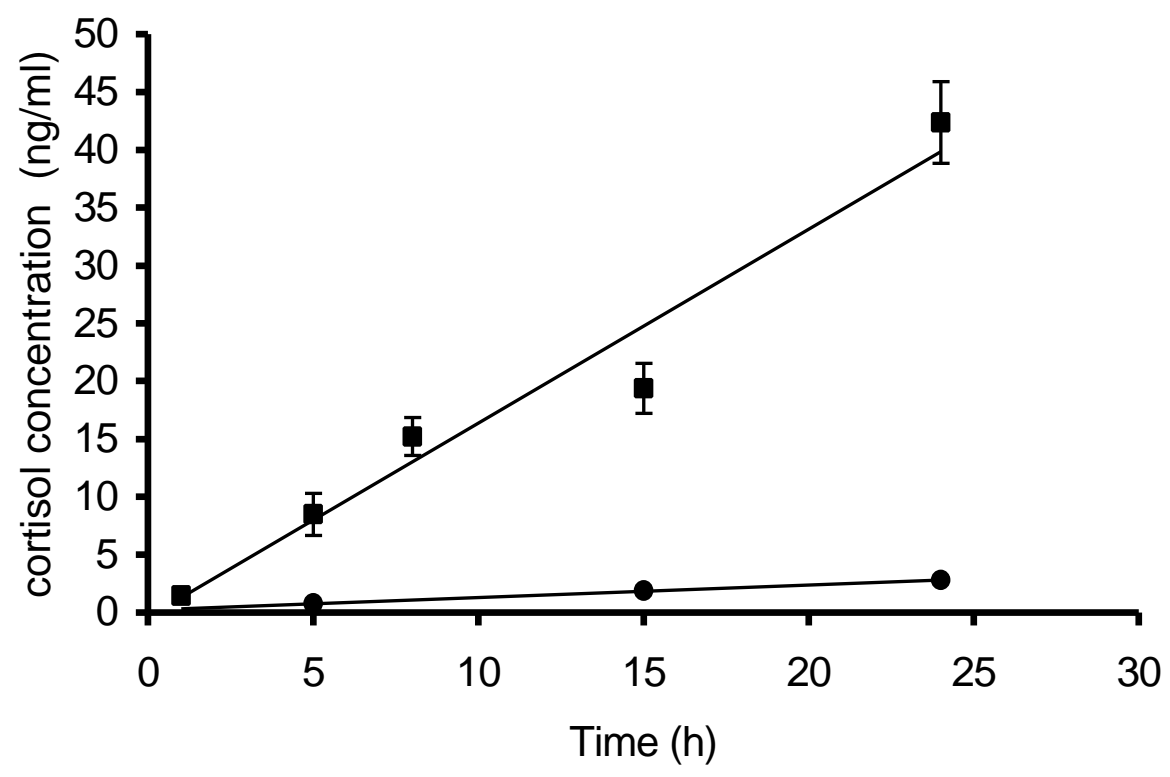

Figure 12. Time-dependency of the stimulation of cortisol with forskolin in $\mathbf{H 2 9 5}$ cells. Basal cortisol release $(\bullet)$ and incubation with $20 \mu \mathrm{M}$ forskolin $(\bullet)$. The medium content of cortisol was determined with RIA. Each point represents a mean \pm SEM from three dishes of 1 representative experiment out of three independent experiments.

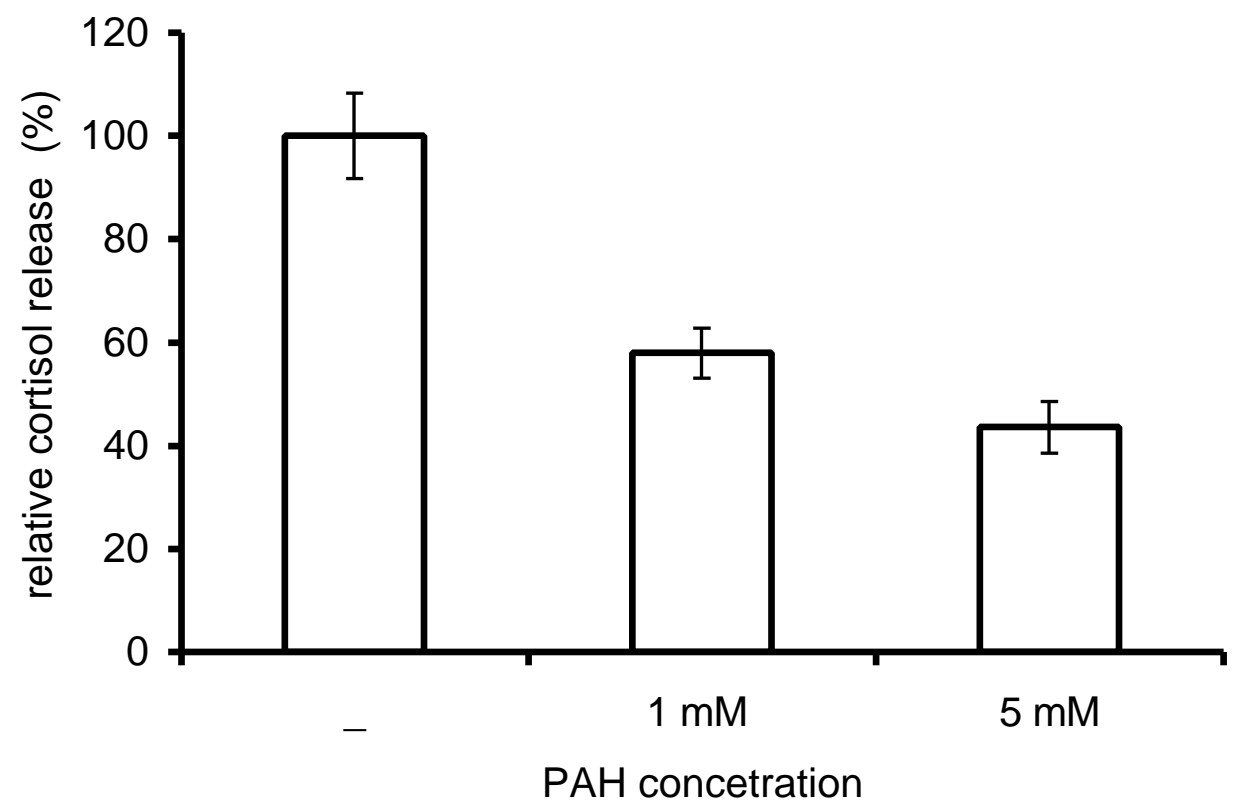

Figure 13. Influence of incubation with PAH on cortisol release from human adrenocortical carcinoma cell line. Cells were incubated with culture medium (-) or with medium supplemented with 1 $\mathrm{mM}$ or $5 \mathrm{mM}$ PAH $(+)$ for 24 hours. Forskolin $(20 \mu \mathrm{M})$ was added to both media. Cortisol release without PAH was set to $100 \%$. Data represent means \pm SEM of two independent experiments with 3 wells per condition. 
To repeat the previous experiments on human cells, the influence of paraaminohippurate in different concentrations was tested on cortisol release (Figure 13.) Cortisol release was inhibited in a concentration-dependent manner, suggesting intracellular accumulation of $\mathrm{PAH}$, which was competing with cortisol for the same transporter.

Probenecid proved to be lethal at a $5 \mathrm{mM}$ concentration or even at a tenfold dilution: the cells started to detach from the bottom after approximately 3 hours and after 24 hours all were dead.

Shorter incubation times ( $1 / 2$ and 1 hour) were chosen to eliminate the side effects of the drug on other physiological functions of the cells, but they had to be long enough to measure cortisol in the supernatant of the cells. The cells were preincubated with forskolin in the further experiments for 24 hours so that cortisol became the major product of the cells.

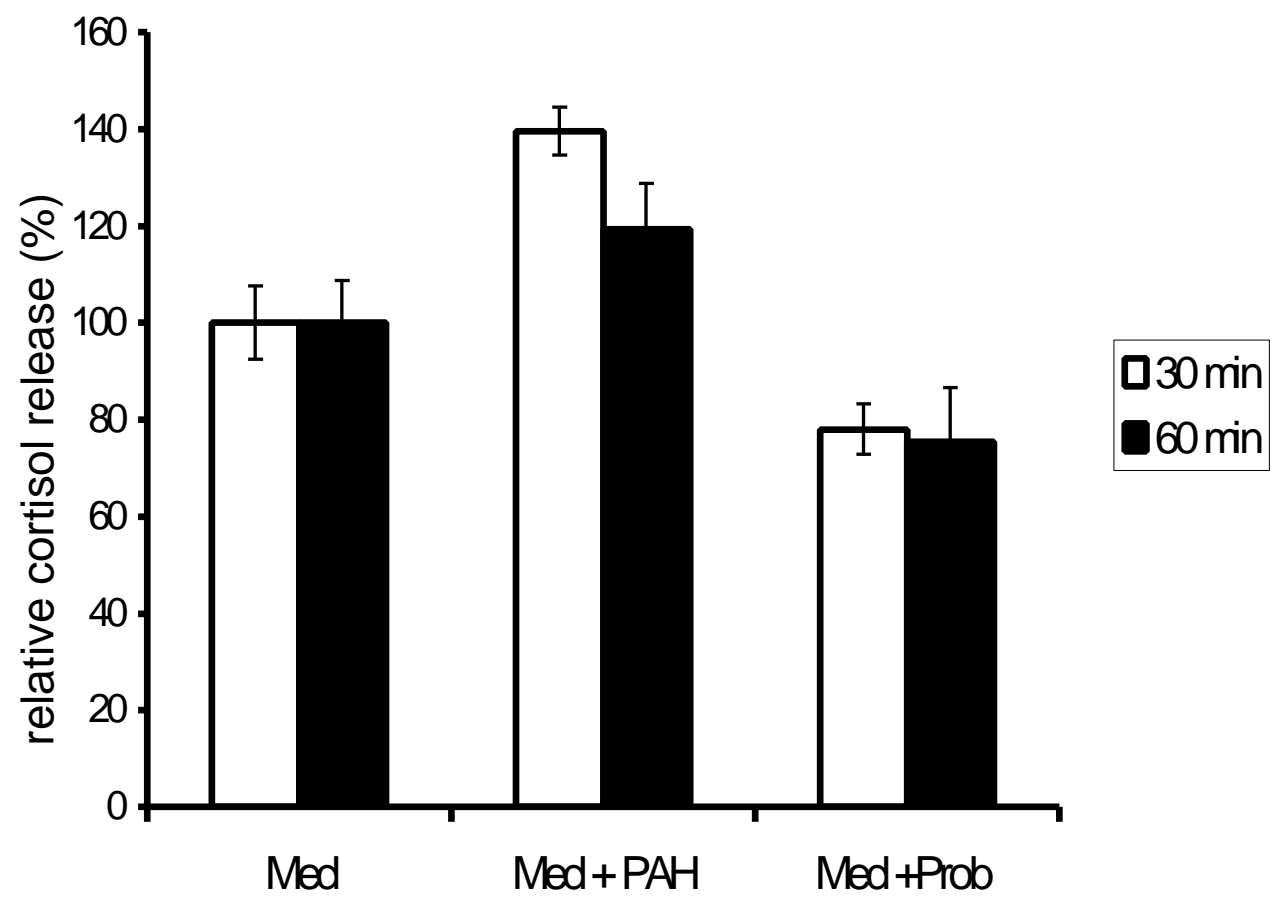

Figure 14. Influence of PAH and probenecid on cortisol release. After 24 hours preincubation with forskolin $(20 \mu \mathrm{M})$ with $1 \mathrm{mM}$ PAH or $5 \mathrm{mM}$ probenecid (Prob) for $30 \mathrm{~min}$ (open column) or $60 \mathrm{~min}$ (filled column). Cortisol release in the absence of substrate was set to $100 \%$. Data represent means \pm SEM of two independent experiments with three wells per condition. 
After 1/2 hour incubation with 1mM PAH, cortisol release was increased about $40 \%$ and after 1 hour about $20 \%$ which indicated trans-stimulation (Fig.14.). Less stimulation of cortisol release by PAH with longer incubation time suggested that PAH was accumulated in the cells. Probenecid had a mild inhibitory effect on cortisol release under that conditions, about $25 \%$ ( Fig.14.).

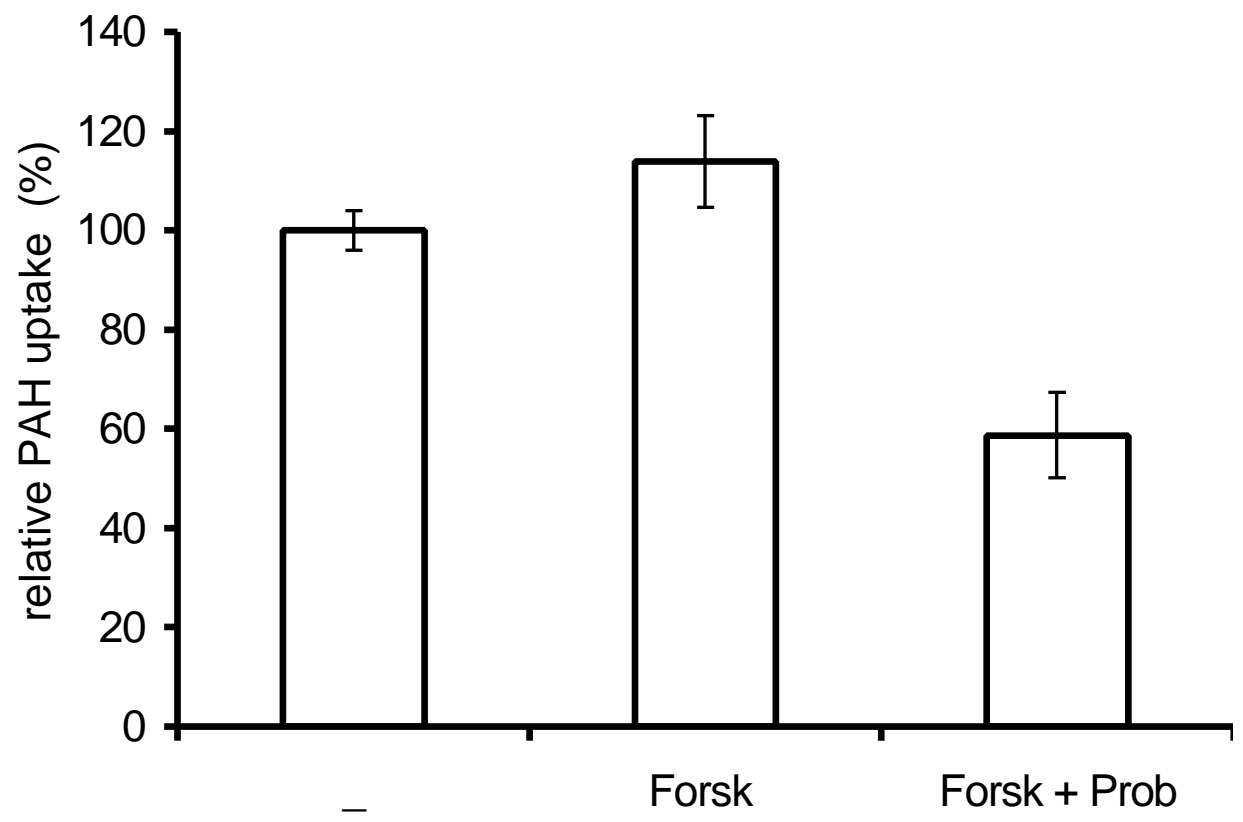

Figure 15. Effect of preincubation with forskolin and inhibition by probenecid on ${ }^{3} \mathrm{H}-\mathrm{PAH}$ uptake into human adrenocortical carcinoma cell line. Cells were incubated with radioactive PAH $(5.5 \mu \mathrm{M})$ for $10 \mathrm{~min}$ with or without preincubation with forskolin for 24 hours. Uptake of PAH was detected in the presence of $5 \mathrm{mM}$ probenecid. PAH uptake in the absence of forskolin and probenecid was set at $100 \%$. Data represent means \pm SEM of four independent experiments with three wells per each condition.

In contrast, 10 min uptake of radioactive para-aminohippurate was not significantly increased after forskolin treatment, but probenecid could inhibit about $40 \%$ of the uptake (Fig.15.). To further prove the concept of an exchanger, cis-inhibition and transstimulation with cortisol and PAH was tested on radioactive PAH uptake.

Preincubation with $1 \mathrm{mM}$ PAH increased by about $35 \%$ radioactive PAH uptake while $\mathrm{PAH}$ in the transport medium inhibited uptake in a concentration dependent manner (two independent experiments Fig.16.). 




Figure 16. Influence of PAH on ${ }^{3} \mathrm{H}-\mathrm{PAH}$ uptake into human adrenocortical carcinoma cell line. Cells were incubated with $5.5 \mu \mathrm{M}^{3} \mathrm{H}-\mathrm{PAH}$ for $10 \mathrm{~min}$ after 24 hours preincubation with $1 \mathrm{mM}$ PAH or with $1 \mathrm{mM}$ and $5 \mathrm{mM}$ PAH in the incubation medium. Uptake of PAH in the absence of addition of nonradioactive PAH was set at $100 \%$. Data represent means \pm SEM of two independent experiments with 3 wells per each condition. 
5 DISCUSSION

\subsection{STEROID HORMONE RELEASE FROM BOVINE ADRECORTICAL CELLS}

The adrenal steroid hormones have a central, important role in the hormonal control, as they have influence on almost every physiological process. For this reason, the synthesis and action of adrenal steroids have been extensively investigated. In contrast, their movement through the plasma membrane is still poorly understood, although this is an important problem of basic biology and medicine. Due to their hydrophobic chemical structure, simple diffusion has been postulated as a release mechanism. However, in vitro studies demonstrated retention of steroids against a concentration gradient at the plasma membrane (Whitehouse et al. 1971, Inaba et al. 1974), whereas the interaction of steroids with carrier proteins in cell membranes has been shown in several studies (Rao et al. 1997, Raven et al. 1982, Thompson et al. 1995, Ullrich et al. 1991, Chen et al. 1996). Moreover, the recently cloned organic anion and organic cation transporter families proved to be able to transport different steroids (Burckhardt et al. 2000). Based on this evidence, it appears likely that transporter participation could be suggested in this process.

\subsubsection{Demonstration and characterisation of a probenecid-inhibitable anion exchanger involved in cortisol release}

It has recently been shown in bovine adrenal cells that basic and ACTH stimulated cortisol release was reduced by probenecid, a characteristic inhibitor of the renal basolateral PAH/dicarboxylate exchanger (Steffgen et al. 1996). Cortisol release was also trans-stimulated by para-aminohippurate itself, suggesting that the mechanism of release may involve a similar transporter. Further evidence for the existence of a renal basolateral PAH transporter-like system in the adrenocortical cells was provided by the expression of probenecid-inhibitable PAH transport after injection of adrenal mRNA into oocytes of Xenopus laevis (Steffgen et al. 1996). 
In the present study, uptake of ${ }^{3} \mathrm{H}-\mathrm{PAH}$ by bovine adrenocortical cells was examined under different conditions to obtain further evidence for such a transport system. Uptake of PAH into the cells could be stimulated with ACTH, consistent with stimulation of cortisol synthesis and subsequent trans-stimulation of PAH uptake by the increased intracellular cortisol concentration, of the exchange partner of PAH. Significant inhibition of PAH uptake into normal and ACTH-stimulated cells was also demonstrated. Nevertheless, the probenecid-inhibitable part of PAH uptake was somewhat lower (55\%) than the probenecid-inhibitable part of cortisol release (63\%). Therefore, it is possible that another transporter(s) is also involved in cortisol release from the adrenal cells. Experimental evidence for the involvement of the other transporter, however, has not been reported in the adrenals. Nor can it not be excluded that part of the inhibiting effect of probenecid on cortisol release might be due to inhibition of cortisol synthesis. However, intracellular cortisol rises in cells incubated with probenecid in comparison to cells which were not incubated with probenecid, indicating that there is no predominant inhibitory effect of probenecid on cortisol synthesis (Steffgen et al. 1996). There was always a residual part of PAH uptake and also cortisol release, which was not inhibited by probenecid and which might be due to simple diffusion.

As characteristic features of an exchange transporter system, trans-stimulation and cisinhibition were tested with the representative substrates of the likely transporter. As the investigated transporter was believed to be an organic anion/dicarboxylate exchanger, glutarate was tested for the ability to inhibit PAH uptake into adrenocortical cells. Significant inhibition was observed with $1 \mathrm{mM}$ glutarate. A higher concentration $(10 \mathrm{mM})$ did not increase the inhibitory effect, demonstrating saturation. This effect fits in with the expected model. Inhibition by cortisol was also investigated in order to ascertain - from the opposite side - whether cortisol can interact with the PAH transport system, to confirm the radioimmunoassay findings, showing that the release of cortisol could be influenced by PAH (Steffgen et al. 1996 and 1999). In the presence of $1 \mathrm{mM}$ cortisol in the transport medium, the uptake of radioactive PAH was significantly inhibited. This can be explained with competition (cis-inhibition) for a common transporter. Similarly to glutarate $1 \mathrm{mM}$, nonradioactive PAH caused cis-inhibition of radioactive $\mathrm{PAH}$ uptake, as has been shown for the renal organic anion transporter system (Berner et al. 1976, Eveloff et al. 1979). Preincubation of the cells with $1 \mathrm{mM}$ $\mathrm{PAH}$ for 1 hour trans-stimulated ${ }^{3} \mathrm{H}-\mathrm{PAH}$ uptake into the cells indicating the presence of 
transporter mediating PAH/PAH self-exchange. A similar effect has been shown for the renal basolateral PAH transport system (Shimada et al. 1987, Schmitt et al. 1993). The result confirms the concept of a carrier-mediated exchange of PAH for cortisol in the bovine adrenocortical cells. Taken together these findings suggest that the disclosed transporter involved in cortisol release in bovine adrenocortical cells is similar to the renal organic anion/dicarboxylate exchanger.

\subsection{DEMONSTRATION OF A Na+-DICARBOXYLATE COTRANSPORTER IN BOVINE ADRENOCORTICAL CELLS}

Side-chain cleavage (SCC) of endogenous cholesterol in adrenal mitochondria isolated from ACTH-treated rats indicates that the size of the reactive cholesterol pool depends, via NADPH, on the reducing precursor (McNamara et al. 1990). McNamara and Jefcoat have elaborated the existence of two pools of reactive cholesterol, one being partially activated by succinate, the other one solely by isocitrate. It has been postulated that these pools are localized in a subpopulation of mitochondria or different pools of activity within mitochondria.

Serum contains a notable level of some Krebs cycle intermediates (e.g. $42 \mu \mathrm{M}$ for succinate or $99 \mu \mathrm{M}$ for citrate in human serum were detected by Krebs in 1950). Northern blots using the luminal dicarboxylate transporter cloned from rabbit kidney as a probe revealed that this transporter is transcribed in the adrenals (Pajor et al. 1995). Therefore, it could be suggested that energy requirement of these cholesterol pools can be activated by Krebs-cycle intermediates transported into the cells via a dicarboxylate transport system. Sodium-dependent dicarboxylate transporters have been well characterized in different organs, but not yet in adrenals. In renal proximal tubules, a $\mathrm{Na}^{+}$-dicarboxylate cotransporter has been described in the basolateral and another one in the luminal membrane (Burckhardt 1989, Wright et al. 1987). Both systems differ with respect to their functional characteristics.

To determine whether these transporters are expressed in the adrenals, uptake of succinate by bovine adrenortical cells was tested. As in all other organs tested so far, the uptake displayed sodium dependence and was saturable with an apparent $\mathrm{K}_{\mathrm{m}}$ value of approximately $150 \mu \mathrm{M}$. This value is between that reported for the high affinity transporter found in the rabbit basolateral membrane of the proximale tubule $(12 \mu \mathrm{M})$ 
and that for the rabbit renal luminal transporter $(610 \mu \mathrm{M})$ (Wright et al. 1987). Lithium inhibition of succinate transport into bovine adrenocortical cells was also demonstrated, similar to the inhibition of both basolateral and luminal dicarboxylate transporters by lithium (e.g., Burckhardt 1989, Wright et al. 1987). This inhibition is probably due to the replacement of one sodium ion by lithium.

A range of dicarboxylates were tested for their ability to cis-inhibit succinate transport in bovine adrenocortical cells. Strong inhibition was observed with fumarate, glutarate and $\alpha$-ketoglutarate, as has been reported for renal basolateral and luminal dicarboxylate transporters. On the other hand, isocitrate and citrate did not affect succinate uptake at physiological $\mathrm{pH}$ in bovine adrenal cells. This differs from the inhibitory effect of citrate on succinate uptake shown for kidney (Wright et al. 1987), liver (Zimmerli et al. 1992), intestine (Wolframm et al. 1994) and placenta (Ogin et al. 1989). Whether another transporter is involved in the uptake of isocitrate and citrate requires further studies. Substrates with trans-configuration (fumarate) were more effective than those with cis-configuration (maleate), as has been reported previously for both the renal luminal and basolateral dicarboxylate transporters (Burckhardt et al. 1984, Ullrich et al. 1984, Wright et al. 1987). Further characterization of this transporter showed no inhibition of succinate uptake by 2,3-dimethylsuccinate or cisaconitate (Steffgen et al. 1999). Both substrates have previously been shown to solely inhibit the basolateral and not - or only weakly - the luminal dicarboxylate transporter in the kidney (Ullrich et al. 1984). Moreover, succinate uptake into adrenocortical cells was higher at $\mathrm{pH} 6.0$ than at $\mathrm{pH} 7.4$ or 8.5 (Steffgen et al. 1999), which distinguishes this system from both the luminal as well as from the basolateral renal dicarboxylate transporters with respects to $\mathrm{pH}$ dependence.

This was the first demonstration of a dicarboxylate transporter in the adrenal gland, which showed some similarities to the renal luminal transporter, as well as differences from both luminal and basolateral transporters. This carrier might supply adrenocortical cells with reducing precursors for cholesterol side-chain cleavage.

\subsection{CORTICOSTERONE TRANSPORT VIA THE CLONED RAT ORGANIC ANION TRANSPORTER (ROAT1)}

In addition to the cellular expression, the previously cloned ROAT1 - reamplified from rat kidney - was tested for the ability to transport corticosterone, the main 
glucocorticoid in rats, when expressed in Xenopus laevis oocytes. In contrast to PAH, corticosterone was not taken up specifically into ROAT-1 injected oocytes, as the radioactivity was approximately as high as in the water-injected control oocytes and also the variation of radioactivity within the groups was high. A possible explanation for this observation could be that the oocyte expression system is not suitable for investigating steroid uptake since the oocyte membrane is repleted with progesterone receptors, which are required for maturation, and corticosterone can bind to this receptor with high affinity (Liu et al. 1993). In addition to binding, the hydrophobicity of corticosterone may allow passive diffusion through the plasma membrane.

The attempt to inject the radioactive corticosterone into the oocytes to measure efflux also failed. One possible reason could be that the steroids were bound to intracellular receptors or to other cytoplasmic components (eg. intracellular lipids).

Finally, the effect of corticosterone of ROAT1-mediated PAH uptake was tested in a cis-inhibition study. Although corticosterone strongly cis-inhibited PAH uptake, this demonstrates only that the transporter interacts with corticosterone, but does so far not demonstrate transport of corticosterone.

\subsection{PCR CLONING OF ORGANIC ANION TRANSPORTERS FROM ADRENAL CDNA}

\subsubsection{Rat renal organic anion transporter 1 (ROAT1)}

Recently, the renal organic anion transporter was cloned from several species (flounder: Wolff et al. 1997; rat: Sweet et al. 1997; human: Reid et al. 1998) and the proteins expressed from the clones showed the same functional characteristics as in the cellular model (Uwai et al. 1998, Wolff et al. 1997, Hosoyamada et al. 1999). The in vitro transport assays with bovine adrenal cells revealed carrier-mediated cortisol release, which showed properties similar to the renal organic anion exchanger. To obtain molecular evidence for the presence of this transporter in the adrenal gland, a homology cloning technique was applied, using the nucleic sequences of the cloned flounder and rat OAT1 to design primers. Since this attempt failed in bovine cDNA, as an alternative rat adrenal cDNA was screened to eliminate the problems according to the species differences. Using a PCR-based cloning strategy, ROAT1 was successfully amplified from rat adrenal cDNA, confirming the assumption that ROAT1 is expressed in the 
adrenal cortex according to the transport results. This was the first molecular evidence for the existence of a transporter, at all, in the adrenal gland.

\subsubsection{Rat organic anion transporting polypeptide family (oatp)}

The bovine transport data suggested the presence of another transporter in adrenals and the participation in cortisol release (Steffgen pers.comm.). Based on the literature, a likely candidate was the organic anion transporting polypeptide (oatp) which represents a polyspecific transporter that can mediate charge-independent uptake of a wide variety of structurally unrelated amphipathic compounds. This broad substrate spectum of oatp includes the organic anions (eg., sulfobromophtalein and bile salts) (Jacquemin et al. 1994, Kullack-Ublick et al. 1994), as well as estrogen conjugates (Bossuyt et al. 1996, Kanai et al. 1996), aldosterone and cortisol (Bossuyt et al. 1996).

In addition the corresponding parameter for cortisol uptake by oatp1 expressed in Xenopus oocytes $\left(\mathrm{K}_{\mathrm{m}}=13.0 \mu \mathrm{M}\right.$ by Bossuyt et al. 1996) was close to the $\mathrm{K}_{\mathrm{m}}$ value for the low affinity transport component of cortisol uptake into isolated rat liver cells (Rao et al. 1976). In contrast to the data of Bossuyt and co-workers, in a transient expression study of oatp1 in HeLa cells, strong inhibition of oatp-mediated sulfobromophthalein uptake by corticosterone and hydrocortisone was found, whereas no transport of these substrates was detected (Kanai et al. 1996). However, conclusions are difficult to draw based on these studies as the two groups did not use the same substrate, because cortisol and corticosterone have very different chemical properties. Nevertheless, demonstrating oatp1 expression in the adrenals was the first step in addressing this question. In addition, besides oatp1, two other members of the rat oatp family had been cloned at the beginning of this study, namely oatp2 (Noé et al. 1997) and oatp3 (Abe et al. 1998), but their characterization was incomplete. To demonstrate oatp in adrenals, a PCR cloning strategy was employed using primers based on homologous parts of the known members of the oatp family. The PCR screening of rat adrenal cDNA disclosed all three oatp transporters. This was the first molecular demonstration of the respective transporters in rat adrenal gland. 


\subsection{LOCALISATION OF ROAT1 AND OATP1, OATP2 AND OATP3 IN RAT ADRENAL GLAND}

In the next step, the transporters revealed by PCR in this study were localized in the different zones of the adrenal gland by non-radioactive in situ hybridization.

The previous results in the other organs showed that the expression of the various members of the investigated transporter family typically appear in a certain place of the organ. In the kidney, oatp1 is localised to the S3 segment of the proximal tubule in the outer medulla (Bergwerk et al. 1996), just as oatp3 (according to our data). In contrast, ROAT1 is expressed in the S2 segment (Tojo et al. 1999). In the liver, oatp1 is expressed in the apical membrane of all hepatocytes (Bergwerk et al. 1996), while oatp2 is found in the basolateral membrane of the hepatocytes around the central vein (Kakyo et al. 1999).

It was a very important issue to determine the localisation of the revealed transporters, as the adrenal gland divides into cortex and medulla, two functionally and originally different parts. The cortex is characterised by a unique anatomical zonation that supports functional diversities, as the three zones produce different steroid hormones. The early steps of the steroidogenesis are all common to all cortical zones, just the late steps are zone specific. In the zona fasciculata and reticularis, corticosterone synthesis depends on the expression of cytochrome P450 11- $\beta$ hydroxylase (P45011 $\beta$ ), which converts 11-deoxycorticosterone to corticosterone, which is the main glucocorticoid in rat, while it is cortisol in bovine and human. The zona reticularis also produces conjugated and sexual steroids. In the zona glomerulosa aldosterone synthesis depends on the expression of cytochrome P450 aldosterone synthase (P450aldo), which converts deoxycorticosterone to aldosterone. The exact zonation of the end enzymes was detected with in situ hybridisation and immunohistochemistry (Ogishima et al. 1992, Ho et al. 1993, Engeland et al. 1997 and Wotus et al. 1998).

A non-radioactive in situ hybridisation method, established and optimized for all probes and the adrenal gland, was adopted to disclose the expression pattern of the investigated transporters. The specific Dig-labelled riboprobes could recognize and detect all 
transporters (ROAT1, oatp1, oatp2 and oatp3), which were previously demonstrated by PCR in the adrenal gland.

\subsubsection{Renal organic anion transporter 1 (ROAT1)}

In the case of ROAT1, the presence in the outer zona fasciculata is congruent whith the nonstimulated expression of P450 11- $\beta$ hydroxylase in the outer zona fasciculata with faint signal in the inner zona fasciculata and zona reticularis, revealed by in situ hybridisation and immunohistochemistry. As the involvement of ROAT1 in corticosterone transport has been suggested from the uptake experiments, this is supported by the co-localized expression with the P45011 $\beta$ enzyme.

It is known that in response to ACTH the adrenal cortex increases the amount of cortisol or corticosterone in the blood. The Engeland and Ho group investigated whether the adrenal gland has the capacity to increase P450 11- $\beta$ hydroxylase expression in response of adrenal activation. The results showed that one injection of high doses of ACTH increased P45011 $\beta$ mRNA within the initial 24 hours after injection and than repeated injections maintained the elevated expression. The response resulted primarily from an expansion of the area of hybridisation in the inner zones of the adrenal cortex, suggesting that ACTH acts to increase the number of cortical cells expressing P45011 $\beta$ mRNA, contributing to the increase of the total message expression in the adrenal cortex. Extension of fasciculata-like cells to the adrenal capsule after chronic ACTH treatment was observed by Pudney et al. in 1984 and the new in situ results showed that the expression of P45011 $\beta$ also appeared in the zona glomerulosa (Engeland et al.1997 and Ho et al.1993). The change of the mitochondrial cristae from the tubular to the vesicular form and the appearance of the P45011 $\beta$ enzyme in the glomerulosa cells suggest that ACTH induced a transformation of the zona glomerulosa cells to zona fasciculata cells (Hornsby et al. 1974, Bertholet 1980, Wolkersdörfer et al. 1998). The recruitment of steroidogenic cells may represent a novel mechanism for amplifying the steroid response to adrenal activation.

Similar gene regulation was assumed for ROAT1, if it takes part in corticosterone release. Therefore, the in situ hybridisation experiments were repeated with ACTHtreated, rats injected with Synacten for 5 days, hypophysectomized and control rats. 
The control and hypophysectomized rats were also injected with neutral saline at the same time as the ACTH-treated rats with the aim of harmonizing the results, as stress has also been shown to increase corticosterone synthesis in the same manner as ACTH (Engeland et al. 1997). The corticosterone concentration in the blood was also determined with corticosterone radioimmunoassay to verify the efficiency of the treatments.

Activation of the adrenal cortex by ACTH increased the amount of ROAT1 mRNA in the same manner as in the case of P45011 $\beta$. The change in hybridisation resulted from an increase in hybridisation area, as the signal was spread into the zona fasciculata and zona reticularis, and cells in the zona glomerulosa also became positive for the transporter. In addition, the effect of lack of ACTH (hypophysectomy) on the expression of the transporter was tested to consider the regulation from the other side. The signal was no longer detectable even in the outer zona fasciculata. These data clearly show that the physiological stimulus produced by ACTH is able to up-regulate the gene expression of ROAT1, as well as that ACTH is required for a basic transcription of ROAT1 gene. On the basis of these results the direct regulation of the transporter by ACTH is suggests link with corticosterone synthesis.

\subsubsection{Organic anion transporting polypeptide 3 (oatp3)}

The result of in situ hybridisation revealed oatp3 mRNA exclusively in the zona glomerulosa of the adrenal gland which produces ouabain, as was recently demonstrated (Beck et al. 1996, Foster et al. 1998) and aldosterone. It was not tested if these compounds are substrates of the transporter, although oatp3 was shown to transport thyroid hormone besides taurocholate (Abe et al. 1998). The transporter was also demonstrated to be expressed in the kidney by Northern Blot analysis. As the kidney is the main target of aldosterone action, this suggests a connection between the transporter and aldosterone. However, according to the data presented here, oatp3 expression was found in the $\mathrm{S} 3$ segment of the proximale tubule, but not in the collecting ducts which are the site of aldosterone action. Because it was not possible to detect taurocholate transport with the oatp3 cDNA cloned in this study, the two possible adrenal substrates, aldosterone and ouabain, could not be tested, leaving the question open for further examination. 
To test whether ACTH has a regulatory effect on oatp3 expression, adrenals from ACTH-treated and hypophysectomized rats were used for detection of any changes in the expression pattern of oatp3. The ACTH-treatment yielded small changes in the intensity of the signal and in hybridisation area, but these were not at all comparable with the large ACTH-induced increases in ROAT1 expression. The decreased amount of oatp3 mRNA in response to the lack of ACTH could be due to the fact that the adrenal requires a certain level of ACTH secretion to maintain its normal structure and function.

\subsubsection{Organic anion transporting polypeptide 1 and 2 (oatp1 and oatp2)}

In contrast to the previously discussed transporters, in situ hybridisation revealed oatp1 and oatp 2 to be expressed only in single cells or small groups of cells in the inner zona fasciculata and zona reticularis, particularly around blood vessels. These were adrenocortical cells, not epithelial cells, based on their morphology. These adrenal cells produce mainly dehydroepiandrosterone(sulfate) (DHEAS) and also sexual steroids (estrogen, progesterone) and a wide range of precursors and metabolites of these steroids. The appearance of these transporters corresponds with the functional data obtained with oatp1 and oatp2 clones, expressed heterologously in Xenopus oocytes (Kullack-Ublick et al. 1998, Kakyo 1999) and HeLa cells (Kanai et al. 1996), which revealed transport of conjugated steroids, such as estradiol $17 \beta-\mathrm{D}$ glucuronide and DHEAS. In the rat which among others, lacks the $17 \alpha$-hydroxylase activity necessary for cortisol and androgen production there is a negligible androgen production, which could account for the rare and specified expression of the above transporters.

\subsubsection{Organic cation transporter 1 and 2 (OCT1 and OCT2)}

In the course of evaluating the results of the bovine cellular transport experiments the possibility of participation of another transporter in cortisol release arose. Although the first candidate, oatp1, was expressed in the rat adrenal, the localisation in the inner cortical zones indicated another function. In the mean time the organic cation transporter family had been further characterized and this came into consideration. 
The kidneys efficiently excrete organic cations of diverse chemical structure. The structural requirements for substrates are a hydrophobic moiety, the ability to form hydrogen bonds and the presence of ionic or partial electrical charges (Ullrich et al. 1994 and 1997). Besides the kidneys, a wide tissue distribution was found for the organic cation transporter family (Burckhardt et al.2000)

As the bovine cellular uptake results with primary adrenocortical cells suggested that another transporter participates in cortisol release, and since oatp1 proved not to be involved in this process in rat, the OCTs got into focus. The investigation of OCTs in the adrenal gland was carried out in collaboration with Prof. Koepsell, who showed cisinhibition by corticosterone of heterologously expressed rat renal OCT1 and OCT2 transporters (Koepsell et al. 1999). The presence of the above family in the adrenal cortex could be also demonstrated with in situ hybridisation. In contrast to the results of the cis-inhibition studies, OCT1 seemed not to be expressed in adrenals, while OCT2 was expressed mainly in zona glomerulosa. Interestingly, the expression of OCT2 crossed the border between the zones, also appearing in the upper cell row of the zona fasciculata, a phenomenon only observed with this transporter. The question of function of OCT2 in adrenals is still open, as it could be involved in glucocorticoid release or in aldosterone or/and ouabain transport, which must be tested.

The effect of ACTH regulation on the expression of OCT2 was also tested as in the case of ROAT1 and oatp3. Direct regulation could not be unambiguously demonstrated, though the expression was diminished in the hypophysectomized individuals due to the reduced adrenal function. ACTH treatment did not influence the expression of OCT2, indicating no connection between the transporter and the glucocorticoid synthesis. Despite the inconclusive results regarding regulation of OCT2 expression in the adrenals, this is the first evidence for zone- and cell-specific expression of OCT2 in the adrenal gland.

For all transporters tested by us in the adrenal gland, only ROAT1 showed clear dependency on ACTH, which indicates indirectly a connection between ROAT1 and the glucocorticoids. In summary, it can be stated that ACTH could stimulate PAH uptake into bovine adrenal cells and could also increase the expression of ROAT1 mRNA in rat adrenals. Furthermore, corticosterone could cis-inhibit PAH uptake by heterologously expressed ROAT1 and the localization and regulation of ROAT1 and P45011 $\beta$ enzyme expression proved to be synchronised. 


\subsection{CLONING AND ANALYSIS OF RAT ADRENAL OATP3}

The whole open reading frame of oatp3 was isolated from rat adrenal cDNA using a proof-reading polymerase enzyme under optimized conditions. As the 3' and 5' UTRs were not known for oatp3, which are required for functional expression in Xenopus protein expression system, the PCR product was placed between the untranslated regions of the flounder sodium dicarboxylate cotransporter, fNaDC-3 (Steffgen et al. 1999). The same strategy was employed for the human OAT1 (Reid pers.comm.) and a recently cloned rabbit OAT1 clone (Bahn et al. 2000). Referring to the characterisation of the above mentioned clones, the fNaDC-3 UTRs seemed to improve the expression of mammalian cDNAs in oocytes (unpublished data).

\subsubsection{Expression of oatp3 in Xenopus oocytes}

The construction of the functional oatp3 clone flanked by fNaDC-3 UTRs was verified with sequencing. The sequence of the adrenal clone proved to be $98 \%$ identical with the original retinal oatp3. The insertion of the oatp3 clone between the fNaDC-3 UTRs occurred in frame and the START and STOP codons were intact. However, a transport assay in Xenopus oocytes with taurocholate as substrate, carried out according to the protocol of Abe and coworkers, with the cloned adrenal oatp3 was unsuccesful. When the whole sequence of this clone was compared on the amino acid sequence level with the original retinal one and also with fragments which were amplified during the screening of the adrenal cDNA for oatps, three point mutations were revealed, suggesting alteration in protein folding. Twice, the original amino acids were replaced with prolins which can brake the secondary structure of the protein. The third divergence in the $11^{\text {th }}$ transmembrane domain, a change from phenylalanin to serin, can also have an influence on the correct folding on steric ground. These changes were reversed using site-directed mutagenesis. After sequencing, the clone was found to correspond to the published sequence. However, the repaired expression clone still did not mediate taurocholate uptake, when injected in Xenopus oocytes. Further attemps are intended after additional improvement of the adrenal oatp3 clone and the experimental conditions. 


\subsection{HUMAN ADRENOCORTICAL CELLS}

The steroid release was investigated in the bovine and rat adrenal model, but naturally the most important was to become acquainted with the mode of glucocorticoid release from human adrenal cells. For this reason, a human adrenocortical carcinoma cell line (NCI-H295) was obtained, which can serve as an in vitro model for human adrenal cell function. Furthermore, the ability of $\mathrm{H} 295$ cell to be manipulated into a cell producing mineralocorticoids, glucocorticoids or C19-steroids provides a valuable model for elucidating the molecular mechanisms which give rise to each of the three distinct zones of the human adrenal cortex (Gazdar et al. 1990, Rainey et al. 1993 and 1994).

Under unstimulated conditions, the cells do not produce cortisol. Significant increases in cortisol synthesis could be seen after 5 hours of forskolin treatment, an agonist of the protein kinase A pathway. Forskolin was used for stimulation of cortisol production, because the previous experiments indicated the lack of response to ACTH treatment (Mountjoy et al. 1994). The reason of the insensitivity was not yet cleared up, but decreased expression of ACTH receptor was assumed (Rainey et al. 1993). Cortisol becomes the major steroid product after 24 hours of forskolin treatment (Rainey et al. 1994). Therefore, in the present study, the cells were pre-treated for 24 hours with forskolin.

On the basis of the bovine experiments, the human adrenocortical cells were tested for the existence of an OAT-like organic anion transporter involved in cortisol relese from the cells. The release of cortisol could be trans-stimulated with $1 \mathrm{mM} \mathrm{PAH}$ and probenecid had a mild inhibitory effect on the release, detected by RIA. In contrast, forskolin could not increase PAH uptake into the cells, but probenecid could inhibit about $40 \%$ of the uptake, which is comparable with the bovine results. The uptake could also be significantly inhibited with $5 \mathrm{mM}$ PAH in the incubation medium, indicating low substrate affinity of the transporter.

Due to the technical difficulties as the cells did neither tolerated probenecid, even in low concentrations, for extended periods of time, nor high concentrations of the investigated substrates the results can only be regarded as preliminary. Those obtained are (in part) consistent with the proposed model of an exchanger mediating cortisol release, but further experiments are needed to characterize this system in human adrenal cells. 
If cortisol is released in human by transport systems, treatment of hypercortisolism (Cushing) by inhibitors of the transporter would be possible and this would be a good alternative to operation, or at least for bridging the time until the patient is in a better condition for operation. 


\section{APPENDIX}

A. MGETEKRVATHEVRCF SKIKMFLLALTWAYVSKPLSGIYMNTMLTQIERQFDIPTSIVGF

R. MGETEKRVATHEVRCFSKIKMFLLALTWAYVSQSLSGIYMNTMLTQIERQFDIPISIVGF

60

60 I

A. INGSFEIGNLLLIIFVSYFGTKLHRP IMIGVGCVIMGLGCFLMSLPHF LMGRYEYETTIS 120

R. INGSFEIGNFLLIIFVSYFGTKLHRP IMIGVGCVIMGLGCFLMSLPHFLMGRYEYETTIS 20 II III

A. PTSNLSSNSFLCMENRSQTLKP TQDPAECIKEMKSLMWIYVLVGNIIRGIGETPIMPLGI 180

R. PTSNLSSNSFLCMENRSQTLKPTQDPAECIKEMKSLMWIYVLVGNI IRGIGETP IMPLGI IV

A. SYIEDFAKSENSPLYIGILETGKVFGP IVGLLLGSFCASIYVDTGSVNTDDLTITPTDTR

R. SYIEDFAKSENSPLYIGILETGKVFGP IVGLLLGSFCAS IYVDTGSVNTDDLTITPTDTR $\mathrm{V}$

A. WVGAWWIGFLICAGVNILSSIPFFFFPKTLPKEGLQDDVDGTNNDKEEKHREKAKEENRG

R. WVGAWWIGFLICAGVNILSSIPFFFFPKTLPKEGLQDDVDGTNNDKEEKHREKAKEENRG VI

A. ITKDF LPFMKSLSCNP IYMLLILTSVLQINAF INMFTF LP KYLEQQYGKSTAEVVLLIGV

R. ITKDFLPFMKSLSCNP IYMLLILTSVLQINAF INMF TFLPKYLEQQYGKSTAEVVLLIGV VII

A. YNLPPICIGYLLIGF IMKKFKITVKKAAYMAFCLSLFEYLLYFLHFMITCDNFPVAGLTA

R. YNLPPICIGYLLIGF IMKKFKITVKKAAYMAFCLSLFEYLLYFLHFMITCDNFPVAGLTA VIII IX

A. LYEGVHHPLYVENKVLADCNRGCSCSTNSWDPVCGDNGLAYMSACLAGCKKSVGTGPNMV

R. LYEGVHHPLYVENKVLADCNRGCSCSTNSWDPVCGDNGLAYMSACLAGCKKSVGTGTNMV

A. FQNCSCIRSSGNSSAVLGLCKKGPECANKLQYFLIMSVIGSFIYSITAIPGYMVLLRCIK 540

R. FQNCSCIRSSGNSSAVLGLCKKGPECANKLQYFLIMSVIGSFIYSITAIPGYMVLLRCIK 540 $\mathbf{X}$

A. PEEKSLGIGLHAFCTRVSAGIPAPIYFGALIDRTCLHWGTLKCGEPGACRMYNINNFRRI 600

R. PEKKSLGIGLHAFCTRVFAGIPAPIYFGALIDRTCLHWGTLKCGEPGACRMYNINNFRRI 600 $\mathrm{XI}$

A. YLVLPAALRGSSYLPALF ILILMRKFQFPGEIDSSETELAEMKITVKKSECTDVHGSPQV

R. YLVLPAALRGSSYLPALF ILILMRKFQFP GEIDSSETELAEMKITVKKSECTDVHGSPQV 660 660 XII

A. ENDGELKTRL 670

R. ENDGELKTRL 670

Appendix 1. Amino acid comparison of the retinal and adrenal oatp3. Residues shaded grey are those different in the retinal and adrenal clone. The putative transmembrane regions are indicated by solid lines (data taken from Abe et al. 1998) A means adrenal, R means retinal. 


\section{LITERATURE}

Abe T, Kakyo M, Sakagami H, Tokui T, Nishio T, Tanemoto M, Nomura H, Hebert SC, Kondo H, Yawo H (1998) Molecular characterisation and tissue destribution of a new organic anion transporter subtype (oatp3) that transports thyroid hormones and taurocholate and comparisom with oatp2. J Biol Chem 273: 22395-22401

Angeletti RH, Novikoff PM, Juvvadi SR, Fritschy J-M, Meier PJ, Wolkoff AW (1997) The choroid plexus epithelium is the site of the organic anion transport protein in the brain. Proc Natl Acad Sci 94: 283-286

Bahn A, Pravitt D, Enklaar T, Reid G, Wolff NA and Burckhardt G (2000) Genomic cloning and characterization of the human renal organic anion transporter gene (hOAT1). FASEB J 14:A106

Basset JR, Pollard I (1980) The involvement of coated vesicles in the secretion of corticosterone by zona fasciculata of the adrenal cortex. Tissue Cell 12: 101-115

Bearn JA and Raven PW (1993) Neuroendocrine developments in psychiatric research. In Kerwin R (Ed.) Cambridge Medical Reviews: Neurobiology and Psychiatry, pp. 7195, Cambridge: Cambridge University Press

Beck M, Szalay KS, Nagy GM, Toth M, de Chatel R (1996) Production of ouabain by rat adrenocortical cells. Endocr Res 4: 845-849

Bergwerk AJ, Shi X, Ford AC, Kanai N, Jacquemin E, Burk RD, Bai S, Novikoff PM, Stieger B, Meier PJ, Schuster VL, Wolkoff AW (1996) Immunologic distribution of an organic anion transport protein in rat liver and kidney. Am J Physiol 271 (Gastrointest. Liver Physiol. 34): G231-G238

Berner W and Kinne R (1976) Transport of p-aminohippuric acid by plasma membrane vesicles isolated from rat kidney cortex. Pflüg Arch-Eur J Physiol 361:269277.

Bertholet JY (1980) Proliferation activity and cell migration in the adrenal cortex of fetal and neonatal rats: an autoradiographic study. J Endocrin 87: 1-9

Bossuyt X, Muller M, Hagenbuch B, Meier PJ (1996) Polyspecific drug and steroid clearance by an organic anion transporter of mammalian liver. J Pharm Exp Ther 276: 891-896

Breitschopf H, Suchanek G, Gould RM, Colman DR, Lassmann H (1992) In situ hybridization with digoxigenin-labeled probes: sensitive and reliable detection method applied to myelinating rat brain. Acta Neuropathol (Berl). 84(6):581-587.

Burckhardt G, (1984) Sodium-dependent dicarboxylate transport in rat renal basolateral membrane vesicles. Pflügers Arch-Eur J Physiol 401: 254-261

Burckhardt G, Ullrich KJ (1989) Organic anion transport across the contraluminal membrane dependence on sodium. Kidney Int 36: 370-377 
Burckhardt G, Wolff NA (2000) Structure of renal organic anion and cation transporters. Am J Physiol Renal Physiol 278: F853-F866

Chen TC, Mackic JB, McComb JG, Gianotta SL, Weiss MH, Zlokovic BV (1996) Cellular uptake and transport of methylprednisolone at the blood-brain barrier. Neurosurgery 38: 348-354

Dempsher DP, Gann DS, Phair RD (1984) A mechanistic model of ACTH-stimulated cortisol secretion. Am J Physiol 246: R587-R596

Di Bartolomeis MJ, Jefcoate CR (1984) Characterisation of the acute stimulation of steroidogenesis in primary bovine adrenel cortical cell cultures. J Biol Chem 259: 10159-10167

Endoh A, Kristiansen SB, Casson PR, Buster JE, Hornsby PJ (1996) The zona reticularis is the site of biosynthesis of dehydroepiendrosterone and dehydroepiandrosterone sulfate in the adult human adrenal cortex resulting from its low expression of 3 beta-hydroxisteroid dehydrogenase. J Clin Endocrinol Metab 81(10): $3558-3565$

Edwards RM, Stack E, Trizna W (1997) Alpha-ketoglutarate transport in rat renal brush-border and basolaterale membrane vesicles. J Pharmacol Exp Ther 281: 10591064

Engeland WC, Levay-Young BK, Rogers LM, Fitzgerald D (1997) Differential gene expression of cytochrome P450 11 $\beta$-hydroxylase in rat adrenal cortex after in vivo activation. Endocrinology 138: 2338-2346

Eveloff J, Kinne R and Kinter WB (1979) p-Aminohippuric acid transport in brush border vesicles isolated from flounder kidney. Am J Physiol 237:F291-F298.

Exton JH (1979) Regulation of gluconeogenesis by glucocorticoids. In Baxter JD and Rousseau GG (Eds) Glucocorticoid Hormone Action, New York: Springer

Gardner DG, Hane S, Trachewsky D, Schenk D, Baxter JD (1986) Atrial natriuretic peptide mRNA is regulated by glucocorticoids in vivo. Biochem Biophys Res Comm 139:1047-1054

Gazdar AF, Oie HK, Shackleton CH, Chen TR, Triche TJ, Myers CE, Chrousos GP, Brennan MF, Stein CA, La Rocca RV (1990) Establishment and characterisation of a human adrenocortical carcinoma cell line that express multiple pathways of steroid biosynthesis. Cancer Research 50: 5488-5496

Gemmell RT, Laychock SG, Rubin RP (1977) Ultrastructural and biochemical evidence for a steroid-containing secretory organelle in the perfused cat adrenal gland. J Cell Biol 72: 209-215

Hahn TJ, Halstead LR, Teitelbaum SL, Hahn BH (1979) Altered mineral metabolism in glucocorticoid-induced osteopenia. Effect of 25-hydroxy vitamin D administration. $J$ Clin Inv 64: 655-665 
Hinson JP, Dawnay AB, Raven PW (1995) Why we should give a cautious welcome to ouabain: a whole new family of adrenal steroid hormones? J Endocrinol 146: 369372

Ho MM, Vinson GP (1993) 11 $\beta$-hydroxylase gene expression in the rat adrenal cortex. J Endocrin 139: 295-300

Hodgkinson A (1963) The realtion between citric acid and calcium metabolism with particular reference to primary hyperparathyreodismum and idiopathic hypercalciuria. Clin Sci (Colch) 24: 167-178

Hornsby PJ, O’Hare MJ, Neville AM (1974) Functional and morphological observations on rat adrenal zona glomerulosa cells in monolayer culture. Endocrinology 95: 1240-1251

Hosoyamada M, Sekine T, Kanai Y and Endou H (1999) Molecular cloning and functional expression of a multispecific organic anion transporter from human kidney. Am J Physiol 276:F122-F128

Inaba M, Kamata K (1974) Mode of existence of corticosterone in adrenal cells with reference to storage and secretion. Endocrinol Jpn 21: 437-447

Jacquemin E, Hagenbuch B, Stieger B, Wolkoff AW, Meier PJ (1994) Expression cloning of a rat liver Na+-independent organic anion transporter. Proc Natl Acad Sci 91: $133-137$

Kakyo M, Sakagami H, Nishio T, Nakai D, Nakagomi R, Tokui T, Matsuno S, Abe T, Yawo H (1999) Immunohistochemical distribution and functional characterisation of an organic anion transporting polypeptide 2 (oatp2). FEBS Letters 445: 343-346

Kanai N, Lu R, Bao Y, Wolkoff AW, Schuster VL (1996) Transient expression of oatp organic anion transporter in mammalian cells: identification of candidate substrates. Am J Physiol 270 (Renal Fluid Electrolyte Physiol. 39): F319-F325

Kanai N, Lu R, Bao Y, Wolkoff AW, Vore M, Schuster VL (1996) Estradiol 17ß-Dglucuronide is a high-affinity substrates for oatp organic anion transporter. Am $J$ Physiol 270 (Renal Fluid Electrolyte Physiol. 39): F326-F331

Kondo H (1985) Immunochemical analysis of the localization of neuropeptides in the adrenal gland. Archives of Histology (Japan) 48: 453-481

Koepsell H, Gorbuolev V, Arndt P (1999) Molecular pharmacology of organic cation transporters in the kidney. J Membr Biol 167: 103-117

Krebs HA (1950) Chemical composition of blood plasma and serum. Annu Rev Biochem 19: 409-430

Liu Z, Patino R (1993) High affinity binding of progesterone to the plasma membrane of Xenopus oocytes: charecteristics of binding and hormonal and developmental control. Biol Reprod 49: 980-988 
McEwen BS (1979) Influences of adrenocortical hormones on pituitary and brain function. In Baxter JD and Rousseau GG (Eds) Glucocorticoid Hormone Action, New York: Springer

McNamara BC, Jefcoate CR (1990) Heterogeneous pools of Cholesterol side-chain cleveage activity in rat adrenal mitochondria from ACTH-treated rats: differential responses to different reducing precursors. Mol Cell Endocrinol 73: 123-134

McNamara BC, Jefcoate CR (1990) Heterougenous pools of cholesterol side-chain cleveage activity in adrenal mitochondria from adrenocoticotropic hormone-treated rats: Reconstruition of the isocitrate response with succinate and low concentrations of isocitrate. Arch Biochem Biophys 283: 464-471

Mellon SH (1994) Neorusteroids: biochemistry, modes of action, and clinical relevance. J Clin Endocrin Metabol 78: 1003-1008

Mendel CM (1989) The free hormone hypothesys: a physiologically based mathematical model. Endocrine Reviews 10: 232-274

Mountjoy KG, Bird IM, Rainey WE, Cone RD (1994) ACTH induces up-regulation of ACTH receptor mRNA in mouse and human adrenocortical cell lines. Mol Cell Endocrinol 99(1): 17-20

Müller J (1988) Regulation of Aldosterone Biosynthesis . Physiological and Clinical Aspects, Monographs on Endocrinology 29, Berlin: Springer

Munck A, Guyre PM, Holbrook NJ (1984) Physiological function of glucocorticoids in stress and their relation to pharmacological actions. Endocrine Reviews 5: 25-44

Noe B, Hagenbuch B, Stieger B, Meier PJ (1997) Isolation of a multispecific organic anion and cardiac glycoside transporter from rat brain. Proc Natl Acad Sci 94: 1034610350

Neville AM, O’Hare MJ (1982) The human adrenal cortex. Berlin: Springer

Ogin C, Grassl SM (1989) Dicarboxylate transport in human placental brush-border membrane vesicles. Biochim Biophys Acta 980: 248-254

Ogishima T, Suzuki H, Hata J-I, Mitani F, Ishimura Y (1992) Zone-specific expression of aldosterone synthase cytochrome P-450 and cytochrome P-45011 $\beta$ in rat adrenal cortex: histochemical basis for the functional zonation. Endocrinology 130: 2971-2977

Pajor AM, Sun N (1996) Functional differences between rabbit and human $\mathrm{Na}^{+}-$ dicarboxylate cotransporters, NaDC-1 and hNaDC-1. Am J Physiol 271: F1093-1099

Pritchard JB (1990) Rat renal cortical slides demonstrate p-aminohippurate/glutarate exchange and sodium/glutarate coupled p-aminohippurate transport. J Pharmacol Exp Ther 255: 969-975 
Povedin RA, Boumendil-Povedin EF, Bujoli-Roche J, Priol C (1980) Effects of probenecid on transport and metabolism of cyclic AMP by isolated rabbit renal tubules. Biochim Biophys Acta 629: 135-142

Raff H (1987) Glucocorticoid inhibition of neurohypophyseal vasopression secretion. Am J Physiol 21: R635-R644

Rainey WE, Bird IM, Sawetawan C, Hanley NA, McCarthy JL, McGee EA, Wester R, Mason JI (1993) Regulation of human adrenal carcinoma cell (NCI-H295) production of C19 Steroids. Journal of Clin Endocrinol and Metab 77: 731-737

Rainey WE, Bird IM, Mason JI (1994) The NCI-H295 cell line: a pluripotent model for human adrenocortical studies. Mol Cell Endocrinol 100: 45-50

Rao ML, Rao GS, Höller M, Breuer H, Schattenberg PJ, Stein WD (1976) Uptake of cortisol by isolated rat liver cells a phenomenon indicative of carrier-mediation and simple diffusion. Hoppe-Seyler`s Physiol Chem 357: 573-584

Raven PW, McCredie E, Vinson GP, Goddard C, Whitehouse BJ (1982) Effects of proteolytic enzymes on steroid release from rat adrenal zona glomerulosa tissue: Evidence for novel steroid-protein complexes. Biochem Biophys Res Commun 104: $1247-1254$

Reid G, Wolff NA, Dautzenberg FM and Burckhardt G (1998) Cloning of a human renal p-aminohppurate transporter, hROAT1. Kidney Blood Press Res 21:233-237.

Rohrbach S, Jarry H, Metten M, Bornstein SR, Muller GA, Steffgen J (1997) Demonstration of a probenecid inhibitable anion exchanger involved in cortisol release and PAH uptake in adrenocortical cells. Pflügers Arch-Eur J Physiol 433 (suppl 6): R26

Schmitt C, Burckhardt G (1993) p-Aminohippurate/2-oxoglutarate exchange in bovine renal brush-border and basolateral vesicles. Pflügers Arch-Eur J Physiol 423: 280-290

Sekine T, Watanabe N, Hosoyamada M, Kanai Y and Endou H (1997) Expression cloning and characterization of a novel multispecific organic anion transporter. $J$ Biol Chem 272:18526-18529

Shannon JA (1938) The renal excretion of phenol red by the aglomerular fishes Opsanus tau and Lophius piscatorius. J Cell Comp Physiol 11: 315-323

Shi X, Bai S, Ford AC, Burk RD, Jacquemin E, Hagenbuch B, Meier PJ, Wolkoff AW (1995) Stabile inducable expression of a functional rat liver organic anion transport protein in HeLa cells. Proc Natl Acad Sci U.S.A. 91: 133-137

Shimada H, Moewes B, Burckhardt G (1987) Indirect coupling to $\mathrm{Na}^{+}$of paminohippuric acid uptake into rat renal basolateral membrane vesicles. Am J Physiol 253: F795-F801

Schmitt C and Burckhardt G (1993) p-Aminohippurate/2-oxoglutarate exchange in bovine renal brush-border and basolateral membrane vesicles. Pflüg Arch-Eur J Physiol 423:280-90. 
Simpson DP (1983) Citrate excretion: a window on renal metabols. Am J Physiol 244: F223-234

Simpson ER, Waterman MR (1988) Regulation of the synthesis of steroidogenic enzymes in adrenal cortical cells by ACTH. Annu Rev Physiol 50: 427-440

Stalmans W and Laloux M (1979) Glucocorticoids and hepatic glycogen metabolism. In Baxter JD and Rousseau GG (Eds) Glucocorticoid Hormone Action, New York: Springer

Steffgen J, Ehrhart-Bornstein M, Bahr V, Herkommer B, Sippell WG, Guse-Behrling H, Franz HE, Scherbaum WA, Bornstein SR (1996) Evidence for the involvement of an anion exchanger in cortisol release from bovine adrenocortical cells. Cell Physiol Biochem 6: 82-92

Steffgen J, Rohrbach S, Beery E, Ersoy D, Jarry H, Metten M, Bornstein SR, Muller GA, Burckhardt G (1999) Demonstration of a probenecid-inhibitable anion exchange involved in the release of cortisol and cAMP and in the uptake of $p$-aminohippurate in bovine adrenocortical cells. Cell Physiol Biochem 9: 72-80

Steffgen J, Tolan D, Beery E, Burckhardt G, Muller GA (1999) Demonstration of a $\mathrm{Na}^{+}$-dicarboxylate cotransporter in bovine adrenocortical cells. Pflügers Arch-Eur $J$ Physiol 438: 860-864

Steffgen J, Burckhardt BC, Langenberg C, Kühne L, Müller GA, Burckhardt G and Wolff NA (1999) Expression cloning and characterization of a novel sodiumdicarboxylate cotransporter from winter flounder kidney. J Biol Chem 274:2019120196.

Sweet DH, Wolff NA, Pritchard JB (1997) Expression cloning and characterisation of ROAT1: The basolateral organic anion transporter in rat kidney. J Biol Chem 272: 30088-30095

Thompson EB (1995) Steroid hormones: Membrane transporters of steroid hormones. Curr Biol 5: 730-732

Tojo A, Sekine T, Nakajima N, Hosoyamada M, Kanai Y, Kimura K, Endou H (1999) Imminohistochemical localization of multispecific renal organic anion transporter 1 in rat kidney. J Am Soc Nephrol 10: 464-471

K-Ublick G-A, Fisch T, Oswald M, Hagenbuch B, Meier PJ, Beuers U, Paumgartner G (1998) Dehydroepiandrosterone sulfate (DHEAS): identification of a carrier protein in human liver and brain. FEBS Letters 424: 173-176

Ullrich KJ, Fasold H, Rumrich G, Kloss S (1984) Secretion and contraluminal uptake of dicarboxylic acids in the proximal convolution of at kidney. Pflügers Arch-Eur J Physiol 400: 241-249

Ullrich KJ, Rumrich G (1988) Contraluminal transport systems in the proxymal renal tubule involved in secretion of organic anions. Am J Physiol 254: F453-F462 
Ullrich KJ, Rumrich G, Papavassiliou F, Hierholzer K (1991) Contraluminal paminohippurate transport in the proximale tubule of the rat kidney. VIII. Transport of corticosteroids. Pflügers Arch-Eur J Physiol 418: 371-382

Ullrich KJ, Rumrich G, David C, Fritzsch G (1993) Bisubstrates: substances that interact with both, renal contraluminal organic anion and organic cation transport systems II. Zwitterionic substrates: dipeptides, cephalosporins, quinolone-carboxylate gyrase inhibitors and phosphamide thiazine carboxylates; nonionizable susbstrates: steroid hormones and cyclophophamides Pflügers Arch-Eur J Physiol 425: 300-312

Ullrich KJ (1994) Specificity of transporters for "organic anions" and "organic cations" in the kidney. Biochim Biophys Acta 1197: 45-62

Ullrich KJ (1997) Renal transporters for organic anions and organic cations. Structural requirements for substrates. J Membr Biol 158: 95-107

Uwai Y, Okuda M, Takami K, Hashimoto Y, Inui K (1998) Functional characterisation of the rat multispecific organic anion transporter OAT1 mediating basolateral uptake of anionic drugs in the kidney FEBS Letters 438: 321-324

Vinson GP, Hinson JP, Toth I (1994) The neuroendocrinology of the adrenal cortex. $J$ Neuroendocrinol 6: 235-246

Vinson GP, Whitehouse BJ, Hinson JP (1992) The Adrenal Cortex, New Jersey: Prentice Hall

Whitehouse BJ, Vinson GP (1971) Compartmental arrangement of steroid precursors and the control of steroid hormone secretion in rat adrenal tissue in vitro. Acta Endocrinol (Copenh) 68: 467-476

Wolff NA, Werner A, Burckhard S, Burckhardt G (1997) Expression cloning and characterisation of a renal organic anion transporter from winter flounder. FEBS Letters 417: $287-291$

Wolffram S, Badertscher M, Scharrer E (1994) Carrier-mediated transport is involved in mucosal succinate uptake by rat large intestine. Exp Physiol 79: 215-226

Wolffram S, Unternahrer R, Grenacher B, Scharrer E (1994) Transport of citrate across the brush-border and basolateral membrane of rat small intestine. Comp Biochem Physiol A Physiol 109: 39-52

Wolkersdörfer GW, Bornstein SR (199?) Tissue remodelling in the adrenal gland. Biochem Pharmacol 2: 167-171

Wotus C, Levay-Young BK, Rogers LM, Gomez-Sanchez CE, Engeland WC (1998) Development of adrenal zonation in fetal rats defined by expression of aldosterone synthase and 11ß-hydroxylase. Endocrinology 139: 4397-4403

Wright SH, Wunz TM (1987) Succinate and citrate transport in renal basolateral and brush-border membranes. Am J Physiol 253: F432-439 
Zimmerli B, O' Neil B, Meier PJ (1992) Identification of sodium-dependent and sodium-independent dicarboxylate transport system in rat liver basolateral membrane vesicles. Pflügers Arch-Eur J Physiol 421: 329-335 


\section{ACKNOWLEDGEMENTS}

I would like to thank the following for people for their support during the course of this study.

Prof. Burckhardt, for his advice, support and direction, and excellent organization of the Graduiertenkolleg.

Dr. Jürgen Steffgen, for his professional support, without which this work would never have been completed.

Prof. Dr. G. A. Müller, for the chance to work in his group.

Prof. Dr. H. W. Heldt and Prof. Dr. K. Jungermann, for acting as Referent and Korreferent, respectively.

Prof. Jarry, Prof. Kaissiling, Prof. Koepsell, Dr. Middel, Dr. Bahn, D. Ersoy, D. Tolan, C. Langenberg, S. Rohrbach and M. Metten, for the profitable cooperation.

All my colleagues in the Abteilung Vegetative Physiologie und Pathophysiologie for making my stay in Göttingen unforgettable, especially, Glen Reid, Yohannes Hagos and Jürgen Langer.

Dr. Natascha A. Wolff, for her personal and professional support in the critical periods.

Barbara and Ibrahim Daas, Andy Fife, Ildikó Varga and Attila Farsang, my indispensable friends in Göttingen and Budapest, for unlimited support, especially during hard time.

My parents and sister, for continued support and encouragement from home. 


\section{BIOGRAPHY}

Name

Date of Birth

Place of Birth

Nationality

$1979-1987$

1987-1991

1992- 1997

October 1997-October 2000
Erzsébet Kornélia Beéry

28. March 1973

Dunaújváros, Hungary

Hungarian

Primary and intermediate school, Petofi István, Dunaújváros, Hungary

High School, Széchenyi István, Dunaújváros, Hungary

Master of Science in Molecular and Immune Biology, at the Eötvös Loránd University of Natural Sciences, Budapest, Hungary

Thesis title: Development of a peptide ELISA for detecting the different subtypes of HIV-1.

$\mathrm{Ph} \mathrm{D}$ at the Georg-August-Universität, Göttingen Member of the DFG-funded Graduiertenkolleg 335, entitled: Clinical, cellular and molecular biology of the internal organs

Thesis title: Cloning and charactorization of organic anion transport systems in the adrenal cortex and their role in steroid release 